LBNL-56207

\title{
Energy Efficiency Standards for Residential and Commercial Equipment: Additional Opportunities
}

\author{
Greg Rosenquist, Michael McNeil, Maithili Iyer, \\ Steve Meyers, and Jim McMahon \\ Environmental Energy Technologies Division \\ Lawrence Berkeley National Laboratory \\ University of California \\ Berkeley, CA 94720
}

September 2004

This work was supported by the National Commission on Energy Policy through the U.S. Department of Energy under Contract No. DE-AC03-76SF00098. 



\section{Table of Contents}

1. Introduction.........................................................

2. Products Considered..................................................

3. Technology Cost-Efficiency Analysis..................................

4. Consumer Impacts Analysis..........................................5

5. Selection of Efficiency Levels for Upgraded Standards..................8

6. Estimation of National Impacts....................................14

7. Value of Energy Savings......................................... 15

8. Results.......................................................16

9. Conclusion....................................................19

References........................................................21

Appendix 1. Methods and Sources Used for the Appliance Cost-Efficiency Analysis

Appendix 2. Calculation of Learning Rate Parameter

Appendix 3. Derivation of Discount Rates

Appendix 4. National Impacts Methodology 



\section{Introduction}

Energy efficiency standards set minimum levels of energy efficiency that must be met by new products. Depending on the dynamics of the market and the level of the standard, the effect on the market for a given product may be small, moderate, or large.

Energy efficiency standards address a number of market failures that exist in the buildings sector. Decisions about efficiency levels often are made by people who will not be responsible for the energy bill, such as landlords or developers of commercial buildings. Many buildings are occupied for their entire lives by very temporary owners or renters, each unwilling to make long-term investments that would mostly reward subsequent users. And sometimes what looks like apathy about efficiency merely reflects inadequate information or time invested to evaluate it. In addition to these sector-specific market failures, energy efficiency standards address the endemic failure of energy prices to incorporate externalities.

In the U.S., energy efficiency standards for consumer products were first implemented in California in 1977. National standards became effective starting in 1988. By the end of 2001, national standards were in effect for over a dozen residential appliances, as well as for a number of commercial sector products. Updated standards will take effect in the next few years for several products. Outside the U.S., over 30 countries have adopted minimum energy performance standards. ${ }^{1}$

Technologies and markets are dynamic, and additional opportunities to improve energy efficiency exist. There are two main avenues for extending energy efficiency standards. One is upgrading standards that already exist for specific products. The other is adopting standards for products that are not covered by existing standards.

In the absence of new and upgraded energy efficiency standards, it is likely that many new products will enter the stock with lower levels of energy efficiency than would otherwise be the case. Once in the stock, it is either impossible or more costly to improve the energy efficiency. Therefore, by not expanding or upgrading energy efficiency standards, opportunities for saving energy would be lost.

In the past two decades, standards have significantly raised the level of energy efficiency for new products. ${ }^{2}$ How much more might be gained by making standards more stringent on products already subject to them, or by extending standards to products not yet covered?

The main goal of this study is to estimate key national impacts of new and upgraded energy efficiency standards for residential and commercial equipment. These impacts approximate the opportunity for national benefits that may be lost if standards are not upgraded and expanded from current levels. This study also identifies the end uses where the largest opportunities exist. 
This analysis was prepared for the National Commission on Energy Policy (NCEP). It uses an analytical approach that is similar in concept to that used by the U.S. Department of Energy (DOE) to set standard levels. It relies on much less data and uses more simplified assumptions than the detailed and complex formulations used in DOE's standard-setting process. The results of this analysis should thus be viewed as a first approximation of the impacts that would actually be achieved by new standards.

Note: All monetary values in this report are in 2002 dollars.

\section{Products Considered}

Within each of the key end uses, we considered equipment standards for specific products, as shown in Table 1. For some of the products listed, we determined that additional standards would not be cost-effective on a national-average basis. These products are listed later.

Products that we did not consider include those listed below. The reasons for not considering them were one or more of the following: (1) a more stringent standard is probably not cost-effective (e.g., clothes dryers); (2) the impact of a new standard would probably be low because the market for the product is small and shrinking (e.g., boilers); and (3) lack of adequate data. We also did not consider plumbing fixtures that can reduce hot water consumption in the residential and commercial sectors.

\section{Residential Equipment:}

Freezer

Clothes dryer

Oil furnace

Boiler

Furnace fan

Cooking equipment

Television

Commercial Equipment:

Electric heat pump

Gas unit heaters

Gas cooking equipment

Commercial clothes washers

Distribution transformers

Miscellaneous -- such as service station equipment, automated teller machines, telecommunications equipment, medical equipment, pumps, emergency electricity generators. 
Table 1: End Uses and Products Considered for Efficiency Standards

\begin{tabular}{|c|c|}
\hline End Use & Products Considered \\
\hline \multicolumn{2}{|l|}{ Residential } \\
\hline Space heating & $\begin{array}{l}\text { Gas furnace } \\
\text { Heat pump }\end{array}$ \\
\hline Air conditioning & $\begin{array}{l}\text { Room air conditioners } \\
\text { Central air conditioner and heat pump }\end{array}$ \\
\hline Refrigeration & Refrigerator \\
\hline Water heating & Electric and gas water heater \\
\hline Clothes washing & Clothes washer \\
\hline Dishwashing & Dishwasher \\
\hline Lighting & Torchiere \\
\hline Electric motors & $\begin{array}{l}\text { Ceiling fan, pool pump, well pump, miscellaneous } \\
\text { small motors }\end{array}$ \\
\hline Household electronics & Various products \\
\hline \multicolumn{2}{|l|}{ Commercial } \\
\hline Space heating & Gas furnace and boiler \\
\hline Air conditioning & $\begin{array}{l}\text { Air-source and water-source air conditioner and heat } \\
\text { pump }\end{array}$ \\
\hline Ventilation & Various products \\
\hline Lighting & $\begin{array}{l}\text { Fluorescent lamp } \\
\text { HID lamp }\end{array}$ \\
\hline Water heating & $\begin{array}{l}\text { Gas-fired storage water heater } \\
\text { Gas-fired instantaneous water heater }\end{array}$ \\
\hline Refrigeration & Various products \\
\hline Office equipment & PC and Other Equipment \\
\hline
\end{tabular}

\section{Technology Cost-Efficiency Analysis}

For each considered product, we estimated the incremental consumer cost of technologies providing higher energy efficiency relative to a specific baseline technology, as well as the associated reduction in annual energy use. Key data sources include the technical analyses published by the Department of Energy (DOE) for its equipment standards rulemakings ${ }^{3}$ and data from the analysis done by the Interlaboratory Working Group for the "Scenarios for a Clean Energy Future" study. ${ }^{4}$

Box 1 provides an example of the key data inputs, sources and results for a product. In this and other cases, we selected the most common type of product to serve as a proxy for the product category. Appendix 1 provides a description of the cost-efficiency analysis for each considered product, as well as the sources of data. 


\section{Box 1: Example of Technology Cost-Efficiency Analysis}

Sector: Residential

End Use: Air conditioning

Product: Room air conditioner

Lifetime (years): 12.5

Baseline Technology: 8,000-13,999 Btu/hr, with louvered sides, without reversing valve, 9.85 EER

\begin{tabular}{|l|c|c|}
\hline & $\begin{array}{c}\text { Technology for 2010 } \\
\text { Standard }\end{array}$ & $\begin{array}{c}\text { Technology for } \\
\text { 2020 Standard }\end{array}$ \\
\hline Description & 10.11 EER & Same as 2010 \\
\hline Increase in consumer first cost* $(\$)$ & $\$ 8$ & $\$ 7$ \\
\hline Annual energy savings* $(\mathrm{kWh})$ & 17 & 4.5 \\
\hline CCE $(\mathbb{4} / \mathrm{kWh})$ & 5.2 & $\$ 5$ \\
\hline Decrease in LCC* $(\$)$ & $\$ 4$ & \\
\hline
\end{tabular}

* Relative to baseline technology with first cost of $\$ 482$ in 2010, annual energy use of $657 \mathrm{kWh}$, and LCC in 2010 of $\$ 930$.

Source(s): U.S. Department of Energy (DOE)-Office of Codes and Standards. 1997. "Technical Support Document for Energy Conservation Standards for Room Air Conditioners, Volume 2 - Detailed Analysis of Efficiency Levels ” Washington, DC.

Our estimates of technology costs in 2010 and 2020 assume that a decline occurs from current costs due to a "learning curve" effect. The central idea is that manufacturers develop efficiencies of production as the industry as a whole matures. Accordingly, an empirical learning curve typically uses cumulative production of the product in question as a measure of experience accumulated. The key impact of this learning is the reduction of input use per product - and thus the cost.

To estimate a "learning parameter" for this study, we relied on an empirical analysis that developed a product-characteristics model of energy-using consumer durables. ${ }^{5}$ As described in Appendix 2, one result of this analysis is estimates of a "learning parameter" for three appliances. Based on the results for the three appliances, we applied a decrease of $1.5 \%$ per year to the current estimates of incremental cost for each product. We also address how the results might change if no learning effect was incorporated. 
For each higher-efficiency technology, we calculated cost-of-conserved-energy (CCE) values that spread the initial incremental cost over the lifetime of the equipment. The CCE in terms of dollars per $\mathrm{kWh}$ or MMBtu (gas) is an expression of the extra first cost incurred to save a unit of energy. Calculation of CCE requires application of a Present Worth Factor (PWF) to spread the initial incremental cost over the lifetime of the equipment. The PWF uses a discount rate to effectively amortize costs over time. We derived average discount rates for consumer costs as shown in Table 2. Appendix 3 provides a discussion of the derivation of these discount rates. The rates reflect adjustment for inflation and for tax impacts (such as deduction of mortgage interest).

Table 2: Discount Rates for Types of Costs

\begin{tabular}{|l|c|l|}
\hline Type of Cost & Discount Rate (\%) & Basis for Rate \\
\hline Residential equipment standards & 5.6 & $\begin{array}{l}\text { Opportunity cost for households of } \\
\text { investment in energy efficiency }\end{array}$ \\
\hline Commercial equipment standards & 6.1 & $\begin{array}{l}\text { Weighted cost of capital for typical } \\
\text { commercial sector enterprises }\end{array}$ \\
\hline
\end{tabular}

\section{Consumer Impacts Analysis}

To estimate the impacts of new and upgraded standards on residential and commercial consumers, we used life-cycle cost (LCC) analysis. The LCC for an appliance includes the initial capital cost and the operating costs over an assumed lifetime, with the operating costs discounted to a present value. Using the data from the technology cost-efficiency analysis, and the discount rates shown above, we calculated the LCC for each technology considered for each product.

For some considered products, technologies that are more energy-efficient than the baseline technology have a higher LCC than the baseline. For these products, we do not include a new or upgraded standard.

Ideally, a consumer impacts analysis should use marginal energy prices to calculate the reduction in energy costs associated with standards. Marginal energy prices are the prices consumers pay for the last unit of energy used in a given billing period. Since marginal prices reflect a change in a consumer's bill associated with a change in energy consumed, such prices are appropriate for determining energy cost savings associated with efficiency standards.

For commercial sector electric end uses, we estimated end-use-specific marginal electricity prices for air conditioning, lighting, and refrigeration. We made use of past analysis by DOE/LBNL on estimating marginal electricity prices for commercial unitary air conditioners in this study. ${ }^{6}$ That analysis looked at actual commercial sector tariffs for utilities across the U.S. to derive the marginal prices faced by consumers. As we did not have similar analysis for commercial sector natural gas prices, we used average prices. 
For residential consumers, we did not have data on marginal energy prices, so we used average electricity and natural gas prices. Given the structure of residential tariffs, one would expect that the difference between marginal and average prices is less in the residential sector than in the commercial sector.

For residential end uses and commercial natural gas end uses, the life-cycle energy costs utilize projections of average sectoral natural gas and electricity prices from the DOE-Energy Information Administration's (DOE-EIA) Annual Energy Outlook 2004 (AEO 2004). ${ }^{7}$ (The $A E O$ projections go through 2025. We extrapolated the projected trends in 2015-2025 to estimate prices for later years.) For commercial sector electric end uses, we applied the trend in the EIA projections to the estimated marginal prices in 2002. Figures 1 and 2 show the price projections used.

We also consider changes in maintenance costs where the standards have a significant impact. 


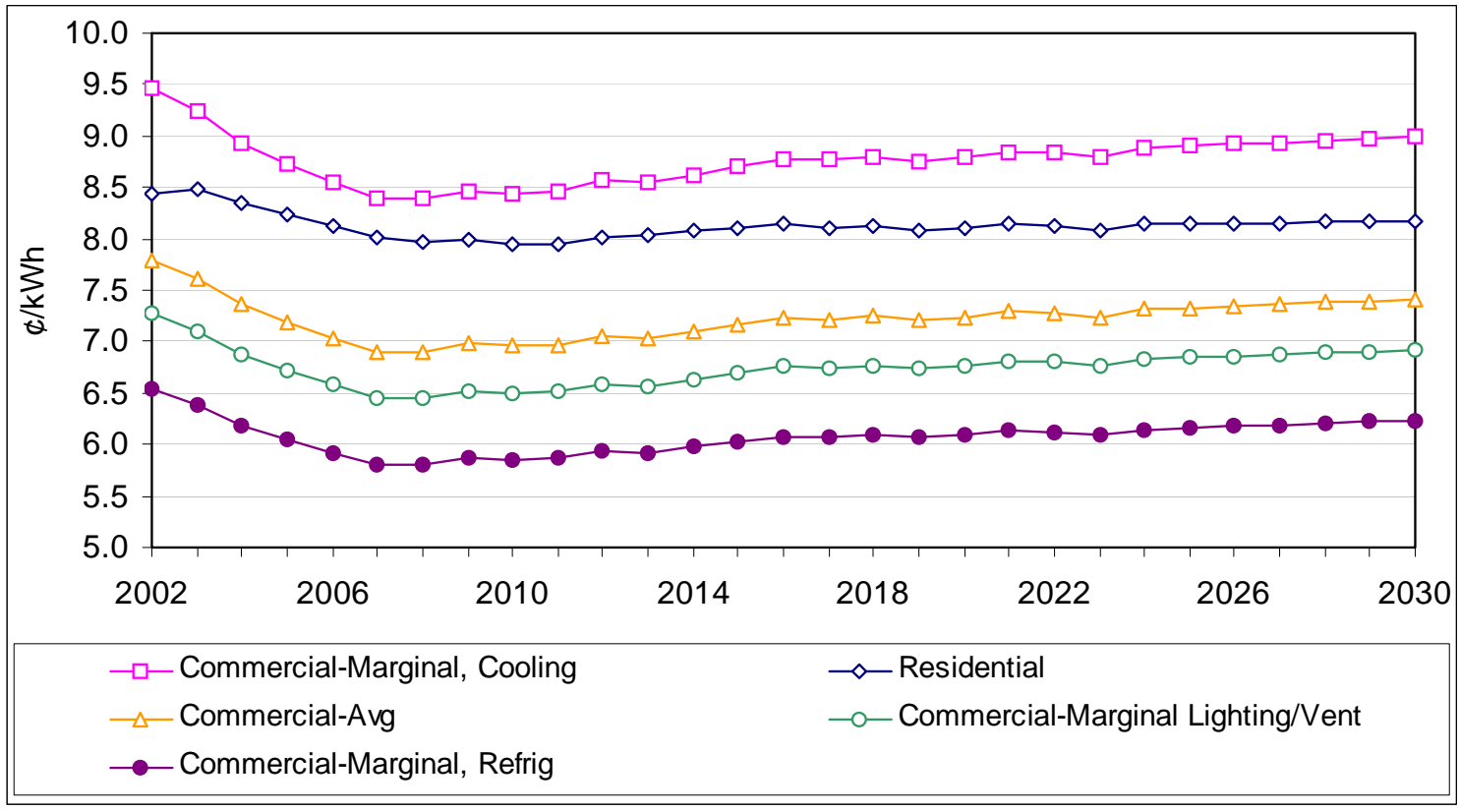

Figure 1: Projected Electricity Prices

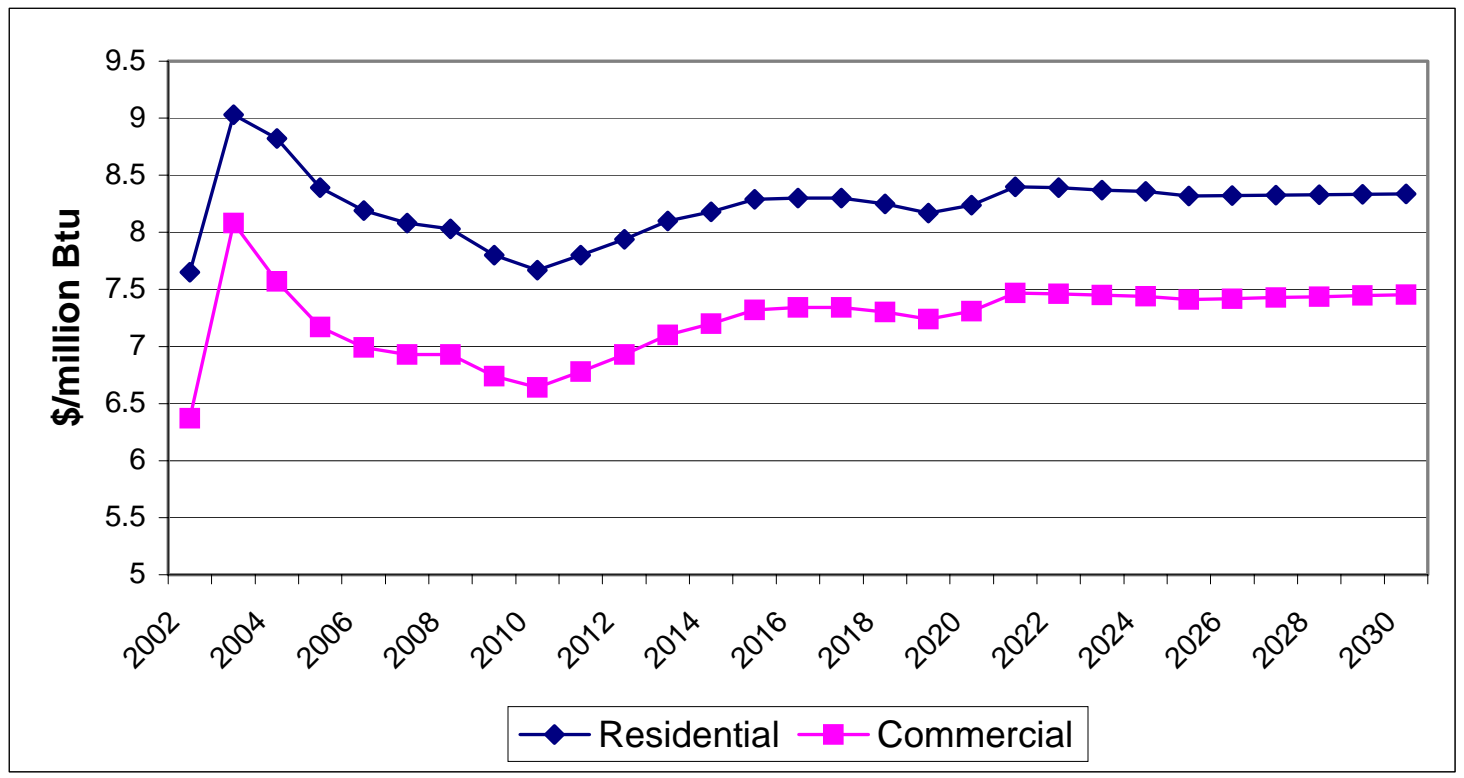

Figure 2: Projected Natural Gas Prices 


\section{Selection of Efficiency Levels for Upgraded Standards}

For each product, we selected the technology with the lowest LCC in 2010 and 2020 for the 2010 and 2020 standards. As mentioned above, new or upgraded standards were not cost-effective relative to the baseline technology for a few of the considered products. Table 3 illustrates the results for the case of residential refrigerators.

Table 3: LCC Example - Residential Refrigerator*

\begin{tabular}{|l|c|c|}
\hline Technology Option & LCC in 2010 & LCC in 2020 \\
\hline $484 \mathrm{kWh} / \mathrm{yr}$ (baseline) & $\$ 1,046$ & $\$ 964$ \\
\hline $473 \mathrm{kWh} / \mathrm{yr}$ & $\$ 1,041$ & $\$ 958$ \\
\hline $444 \mathrm{kWh} / \mathrm{yr}$ & $\$ 1,030$ & $\$ 945$ \\
\hline $437 \mathrm{kWh} / \mathrm{yr}(2010 \mathrm{std})$ & $\$ 1,029$ & $\$ 943$ \\
\hline $426 \mathrm{kWh} / \mathrm{yr}$ & $\$ 1,031$ & $\$ 943$ \\
\hline
\end{tabular}

* Top-mount freezer with auto-defrost

Tables 4 and 5 show the technologies selected for 2010 and 2020 standard levels and their cost of conserved energy for the residential and commercial sectors, respectively. For many products, an upgrade of the 2010 standard in 2020 is not cost-effective, so the 2020 standard is the same as the 2010 standard. Note that even if the standard is the same, the CCE is lower in 2020 due to the assumed decrease in equipment costs over time. Table 6 shows the relevant energy prices to which the CCEs may be compared.

Product standards that were considered but judged not cost-effective on a nationalaverage basis are those for central air conditioners, electric heat pumps, gas water heaters, and clothes washers. In each case, new DOE standards either took effect in 2004 or will take effect in 2006-07. Improvement beyond those standards is not cost-effective given the costs and energy prices currently envisioned. 
Table 4: Technologies Selected for Upgraded Standards - Residential Sector

\begin{tabular}{|c|c|c|c|c|c|}
\hline End Use/Product & $\begin{array}{c}\text { Baseline } \\
\text { Technology }\end{array}$ & $\begin{array}{l}\text { Technology for } \\
2010 \text { Standard }\end{array}$ & $\begin{array}{c}\text { CCE for } 2010 \\
\text { Standard }\end{array}$ & $\begin{array}{l}\text { Technology for } \\
2020 \text { Standard }\end{array}$ & $\begin{array}{c}\text { CCE for } 2020 \\
\text { Standard }\end{array}$ \\
\hline \multicolumn{6}{|l|}{ Space heating } \\
\hline Gas furnace & 80\% AFUE & $\begin{array}{l}\text { 81\% AFUE using } \\
\text { 2-stage modulation }\end{array}$ & $\$ 6.20 /$ MMBtu & Same as 2010 & \$5.40/MMBtu \\
\hline \multicolumn{6}{|l|}{ Air conditioning } \\
\hline Room air conditioner & 9.85 EER & 10.11 EER & $5.2 థ / \mathrm{kWh}$ & Same as 2010 & $4.5 \$ / \mathrm{kWh}$ \\
\hline Refrigeration & $484 \mathrm{kWh} / \mathrm{yr}$ & $426 \mathrm{kWh} / \mathrm{yr}$ & $4.9 \nsubseteq / \mathrm{kWh}$ & Same as 2010 & $4.2 \$ / \mathrm{kWh}$ \\
\hline \multicolumn{6}{|l|}{ Lighting } \\
\hline Torchiere & Incandescent & Fluorescent & $6.8 \nsubseteq / \mathrm{kWh}$ & Same as 2010 & $5.9 \$ / k W h$ \\
\hline \multicolumn{6}{|l|}{ Water heating } \\
\hline Electric & $92 \mathrm{EF}$ & $92 \mathrm{EF}$ & $\mathrm{n} / \mathrm{a}$ & Heat pump & $3.9 \$ / k W h$ \\
\hline Dishwashing* & $2.14 \mathrm{kWh} /$ cycle & $1.96 \mathrm{kWh} /$ cycle & $4.2 థ / \mathrm{kWh}$ & Same as 2010 & $3.6 \mathrm{c} / \mathrm{kWh}$ \\
\hline \multicolumn{6}{|l|}{ Motors } \\
\hline Ceiling fans & Current practice & Higher efficiency & $3.4 \nsubseteq / \mathrm{kWh}$ & Same as 2010 & $2.9 \$ / \mathrm{kWh}$ \\
\hline Pool pumps & Single-Speed & Two-Speed & $4.6 \nsubseteq / \mathrm{kWh}$ & Same as 2010 & $4.0 \pitchfork / \mathrm{kWh}$ \\
\hline \multicolumn{6}{|l|}{ Electronics** } \\
\hline Audio & Current practice & 1 watt standby & $1.2 \Phi / \mathrm{kWh}$ & Same as 2010 & $1.0 \$ / \mathrm{kWh}$ \\
\hline Settop box & Current practice & 7 watt standby & $0.3 \$ / \mathrm{kWh}$ & Same as 2010 & $0.2 \$ / \mathrm{kWh}$ \\
\hline Telephony & Current practice & 1 watt standby & $4.0 \nsubseteq / \mathrm{kWh}$ & Same as 2010 & $3.5 \$ / \mathrm{kWh}$ \\
\hline Microwave oven & Current practice & 1 watt standby & $0.3 \nsubseteq / \mathrm{kWh}$ & Same as 2010 & $0.2 \Phi / \mathrm{kWh}$ \\
\hline Misc. electronics & Current practice & 1 watt standby & $1.5 \$ / k w h$ & Same as 2010 & $1.3 \$ / \mathrm{kwh}$ \\
\hline
\end{tabular}

* The values include the energy savings from reduced water heating associated with a higher-efficiency dishwasher.

** This category does not include TVs or computers and associated equipment. 
Table 5: Technologies Selected for Upgraded Standards -- Commercial Sector

\begin{tabular}{|c|c|c|c|c|c|}
\hline End Use/Product & $\begin{array}{c}\text { Baseline } \\
\text { Technology }\end{array}$ & $\begin{array}{l}\text { Technology for } \\
2010 \text { Standard }\end{array}$ & $\begin{array}{c}\text { CCE for } 2010 \\
\text { Standard }\end{array}$ & $\begin{array}{l}\text { Technology for } \\
2020 \text { Standard }\end{array}$ & $\begin{array}{c}\text { CCE for } 2020 \\
\text { Standard }\end{array}$ \\
\hline Space Heating & Thermal Effc'y & Thermal Effc'y & \$/MMBtu & Thermal Effc'y & \$/MMBtu \\
\hline Packaged Boilers, Gas-Fired, HW (400 kBtu/hr) & $75 \%$ & $79 \%$ & 1.00 & same as 2010 & 0.90 \\
\hline Packaged Boilers, Gas-Fired, HW (800 kBtu/hr) & $75 \%$ & $78 \%$ & 3.30 & $88 \%$ & 5.00 \\
\hline Packaged Boilers, Gas-Fired, HW (1500 kBtu/hr) & $75 \%$ & $88 \%$ & 2.70 & same as 2010 & 2.30 \\
\hline Packaged Boilers, Gas-Fired, HW (3000 kBtu/hr) & $75 \%$ & $88 \%$ & 1.60 & same as 2010 & 1.40 \\
\hline Packaged Boilers, Gas-Fired, Steam (400 kBtu/hr) & $72 \%$ & $76 \%$ & 3.30 & same as 2010 & 2.80 \\
\hline Packaged Boilers, Gas-Fired, Steam (800 kBtu/hr) & $72 \%$ & $76 \%$ & 2.90 & same as 2010 & 2.50 \\
\hline Packaged Boilers, Gas-Fired, Steam (1500 kBtu/hr) & $72 \%$ & $79 \%$ & 3.30 & same as 2010 & 2.80 \\
\hline Packaged Boilers, Gas-Fired, Steam (3000 kBtu/hr) & $72 \%$ & $80 \%$ & 1.90 & same as 2010 & 1.70 \\
\hline Warm-Air Furnaces, Gas-Fired (250 kBtu/hr) & $78 \%$ & $80 \%$ & 6.50 & same as 2010 & 5.60 \\
\hline Warm-Air Furnaces, Gas-Fired (400 kBtu/hr) & $78 \%$ & $80 \%$ & 5.10 & same as 2010 & 4.40 \\
\hline Air conditioning & EER & EER & $\$ / k W h$ & EER & \$/kWh \\
\hline 3-Phase, Single-Package, Air-Source AC (<65 kBtu/h) & 9.7 & 12 & 4.2 & same as 2010 & 3.6 \\
\hline 3-Phase, Split-System, Air-Source AC ( $<65$ kBtu/h) & 10 & 12 & 6 & same as 2010 & 5.2 \\
\hline 3-Phase, Single-Package, Air-Source HP ( $<65$ kBtu/h) & 9.7 & 12 & 4.6 & same as 2010 & 3.9 \\
\hline 3-Phase, Split-System, Air-Source HP (<65 kBtu/h) & 10 & 13 & 5.2 & same as 2010 & 4.5 \\
\hline Central, Air-Source AC (>65 kBtu/h and $<135 \mathrm{kBtu} / \mathrm{h})$ & 10.1 & 11.5 & 3.2 & 12 & 4.5 \\
\hline Central, Air-Source HP ( $>65$ kBtu/h and $<135$ kBtu/h) & 10.1 & 11.5 & 3.2 & 12 & 4.5 \\
\hline Central, Water-Source HP (>65 kBtu/h and $<135$ kBtu/h) & 12 & 12.5 & 7.2 & 13 & 7.4 \\
\hline Central, Water-Cooled AC (>65 kBtu/h and <135 kBtu/h) & 11.5 & 12.4 & 5.9 & 14 & 6.9 \\
\hline Central, Air-Source AC (>135 kBtu/h and <240 kBtu/h) & 9.5 & 11.5 & 2.7 & 12 & 3.6 \\
\hline Central, Air-Source HP (>135 kBtu/h and <240 kBtu/h) & 9.5 & 11.5 & 2.7 & 12 & 3.6 \\
\hline Central, Water-Cooled AC (>135 kBtu/h and <240 kBtu/h) & 11 & 11.5 & 2.9 & same as 2010 & 2.5 \\
\hline Central, Water-Cooled AC (<65 kBtu/h) & 12.1 & 12.1 & 0 & 12.5 & 7.5 \\
\hline Central, Water-Source HP (<17 kBtu/h) & 11.2 & 11.2 & 0 & 12.5 & 7.8 \\
\hline Central, Water-Source HP (>17 kBtu/h and $<65$ kBtu/h) & 12 & 13.1 & 7.1 & same as 2010 & 6.1 \\
\hline Packaged Terminal Air Conditioners (PTACs) $(<7 \mathrm{kBtu} / \mathrm{h})$ & 9.4 & 11 & 5.8 & same as 2010 & 5.0 \\
\hline Packaged Terminal Air Conditioners (PTACs) (7-10 kBtu/h) & 9 & 10.8 & 3.8 & same as 2010 & 3.3 \\
\hline Packaged Terminal Air Conditioners (PTACs) (10-13 kBtu/h) & 8.3 & 10.5 & 4.1 & same as 2010 & 3.6 \\
\hline Packaged Terminal Air Conditioners (PTACs) (>13 kBtu/h) & 7.9 & 10 & 1.9 & same as 2010 & 1.7 \\
\hline Packaged Terminal Heat Pumps (PTHPs) $(<7 \mathrm{kBtu} / \mathrm{h})$ & 9.3 & 10.8 & 5.8 & same as 2010 & 5.0 \\
\hline Packaged Terminal Heat Pumps (PTHPs) (7-10 kBtu/h) & 8.9 & 10.6 & 3.4 & 11.4 & 4.5 \\
\hline Packaged Terminal Heat Pumps (PTHPs) (10-13 kBtu/h) & 8.2 & 9.7 & 2.8 & same as 2010 & 2.4 \\
\hline Packaged Terminal Heat Pumps (PTHPs) (>13 kBtu/h) & 7.8 & 10 & 4.7 & same as 2010 & 4.0 \\
\hline Ventilation & Efficiency & Efficiency & $\$ / k W h$ & Efficiency & \$/kWh \\
\hline \multicolumn{6}{|l|}{ Air Distribution } \\
\hline Large Unitary (10 HP) & $85 \%$ & $92 \%$ & 0.5 & same as 2010 & 0.4 \\
\hline Exhaust Fan (0.5 HP) & $60 \%$ & $80 \%$ & 0.2 & same as 2010 & 0.2 \\
\hline Room Fan Coil (0.17 HP) & $50 \%$ & $75 \%$ & 0.9 & same as 2010 & 0.7 \\
\hline Central Station Air Handling Unit (10 HP) & $87 \%$ & $93 \%$ & 0.6 & same as 2010 & 0.5 \\
\hline \multicolumn{6}{|l|}{ Hydronic Hot and Chilled Water Circulation } \\
\hline Centrifugal Chiller (25 HP) & $90 \%$ & $95 \%$ & 0.5 & same as 2010 & 0.5 \\
\hline Screw Chiller (10 HP) & $90 \%$ & $94 \%$ & 1.4 & same as 2010 & 1.2 \\
\hline
\end{tabular}




\begin{tabular}{|c|c|c|c|c|c|}
\hline End Use/Product & $\begin{array}{c}\text { Baseline } \\
\text { Technology }\end{array}$ & $\begin{array}{l}\text { Technology for } \\
2010 \text { Standard }\end{array}$ & $\begin{array}{c}\text { CCE for } 2010 \\
\text { Standard }\end{array}$ & $\begin{array}{l}\text { Technology for } \\
2020 \text { Standard }\end{array}$ & $\begin{array}{c}\text { CCE for } 2020 \\
\text { Standard }\end{array}$ \\
\hline Reciprocating Chiller (10 HP) & $88 \%$ & $93 \%$ & 1.5 & same as 2010 & 1.3 \\
\hline Absorption Chiller (25 HP) & $90 \%$ & $95 \%$ & 0.5 & same as 2010 & 0.4 \\
\hline Hydronic heating (10 HP) & $90 \%$ & $94 \%$ & 0.8 & same as 2010 & 0.7 \\
\hline \multicolumn{6}{|l|}{ Cooling Water Circulation } \\
\hline Centrifugal Chiller (25 HP) & $90 \%$ & $95 \%$ & 0.5 & same as 2010 & 0.4 \\
\hline Screw Chiller (10 HP) & $90 \%$ & $94 \%$ & 1.0 & same as 2010 & 0.9 \\
\hline Reciprocating Chiller (10 HP) & $88 \%$ & $93 \%$ & 1.9 & same as 2010 & 1.6 \\
\hline Lithium Bromide Water Absorption Chiller (25 HP) & $90 \%$ & $95 \%$ & 0.5 & same as 2010 & 0.4 \\
\hline \multicolumn{6}{|l|}{ Heat Rejection } \\
\hline Large Unitary (5 HP) & $85 \%$ & $90 \%$ & 1.4 & same as 2010 & 1.2 \\
\hline Air Cooled Screw Chillers (2 HP) & $85 \%$ & $92 \%$ & 0.1 & same as 2010 & 0.1 \\
\hline Air Cooled Reciprocating Chillers (2 HP) & $85 \%$ & $92 \%$ & 0.1 & same as 2010 & 0.1 \\
\hline Cooling Tower (10 HP) & $85 \%$ & $92 \%$ & 1.4 & same as 2010 & 1.2 \\
\hline Water Heating & Thermal Effc'y & Thermal Effc'y & \$/MMBtu & Thermal Effc'y & \$/MMBtu \\
\hline Storage Water Heater, Gas-Fired (120 kBtu/hr) & $80 \%$ & $82 \%$ & 4.00 & same as 2010 & 3.50 \\
\hline Storage Water Heater, Gas-Fired (199 kBtu/hr) & $80 \%$ & $82 \%$ & 4.10 & same as 2010 & 3.50 \\
\hline Storage Water Heater, Gas-Fired (360 kBtu/hr) & $80 \%$ & $82 \%$ & 4.30 & same as 2010 & 3.70 \\
\hline Instantaneous Water Heater, Gas-Fired (1000 kBtu/hr) & $80 \%$ & $83 \%$ & 4.80 & same as 2010 & 4.10 \\
\hline Instantaneous Tank Water Heater, Gas-Fired (500 kBtu/hr) & $80 \%$ & $82 \%$ & 4.30 & same as 2010 & 3.70 \\
\hline Lighting* & Technology & Technology & $\Phi / \mathrm{kWh}$ & Technology & $\Phi / \mathrm{kWh}$ \\
\hline Fluorescent Lamp/ballast & Current Practice & $\begin{array}{c}\text { Hi-perf T8 w/elec and } \\
\text { hi-perf ballast }\end{array}$ & 1.9 & $\begin{array}{c}\text { Hi-perf T8 w/ hi-perf } \\
\text { ballast }\end{array}$ & 1.1 \\
\hline HID -- Lo Bay & $\begin{array}{c}\text { MV 20\%, MH 55\%, } \\
\text { HPS 25\% } \\
\end{array}$ & $\begin{array}{c}\text { PMH 75\% \& HPS } \\
25 \% \\
\end{array}$ & 3.0 & $\begin{array}{c}\text { PMH/SSB 75\% \& } \\
\text { HPS 25\% } \\
\end{array}$ & 2.9 \\
\hline HID -- Hi Bay & \begin{tabular}{|c|} 
MV 20\%, MH 55\%, \\
HPS $25 \%$
\end{tabular} & $\begin{array}{c}\text { PMH } 75 \% \text { \& HPS } \\
25 \%\end{array}$ & 1.0 & $\begin{array}{c}\text { PMH/SSB } 75 \% \& \\
\text { HPS } 25 \%\end{array}$ & 1.0 \\
\hline Refrigeration & Technology & $\begin{array}{c}\text { Effc'y } \\
\text { Improvement }\end{array}$ & $\$ / k W h$ & $\begin{array}{c}\text { Effc'y } \\
\text { Improvement }\end{array}$ & $\$ / \mathrm{kWh}$ \\
\hline Supermarket Units & Current technology & $16 \%$ & 1.2 & same as 2010 & 1.1 \\
\hline Beverage Merchandiser Units & Current technology & $61 \%$ & 2.1 & same as 2010 & 1.8 \\
\hline Reach-in Freezers & Current technology & $52 \%$ & 2.5 & same as 2010 & 2.3 \\
\hline Reach-in Refrigerators & Current technology & $38 \%$ & 1.9 & same as 2010 & 1.6 \\
\hline Ice Machines & Current technology & $23 \%$ & 2.8 & same as 2010 & 2.4 \\
\hline Refrigerated Vending Machines & Current technology & $51 \%$ & 2.9 & same as 2010 & 2.5 \\
\hline Walk-in Coolers & Current technology & $46 \%$ & 1.2 & same as 2010 & 1.0 \\
\hline Walk-in Freezers & Current technology & $48 \%$ & 3.0 & same as 2010 & 2.6 \\
\hline \multicolumn{6}{|l|}{ Office equipment } \\
\hline Personal Computers \& Monitors & Current technology & Low standby & 1.0 & Not applicable & 0.1 \\
\hline Other & Current technology & Low standby & 1.0 & Not applicable & 0.2 \\
\hline
\end{tabular}

* MV = mercury vapor; $\mathrm{MH}=$ metal halide; HPS = high-pressure sodium; $\mathrm{PMH}$ = pulse metal halide; $\mathrm{SSB}=$ solid-state ballast 
Table 6: Energy Prices for CCE Comparison

\begin{tabular}{|c|c|c|}
\hline & $\begin{array}{c}\text { Residential } \\
\text { Sector }\end{array}$ & $\begin{array}{c}\text { Commercial } \\
\text { Sector }\end{array}$ \\
\hline Electricity ( $\mathbb{} / \mathrm{kWh})$ & & \\
Price in 2010-20 period & $8.5-9.0$ & $7.0-7.2^{*}$ \\
Price in 2020-30 period & $8.8-9.0$ & $7.2-7.4^{*}$ \\
\hline Natural gas (\$/MMBtu) & & \\
Price in 2010-20 period & $7.7-8.3$ & $6.7-7.3$ \\
Price in 2020-30 period & 8.4 & 7.4 \\
\hline
\end{tabular}

* These are average prices. Prices are 8.5-9.0 $\mathrm{\&} / \mathrm{kWh}$ for air conditioning, 6.5-6.9 $\mathrm{\$} / \mathrm{kWh}$ for lighting and ventilation, and 5.8-6.1 $\mathrm{\$} / \mathrm{kWh}$ for refrigeration. See Figure 1.

As Figures 3 and 4 illustrate, the CCE for the 2010 standards is well below the relevant energy price for most products. This result indicates that most of the standards would be cost-effective even if we did not assume that manufacturing costs decline over time due to a learning effect.

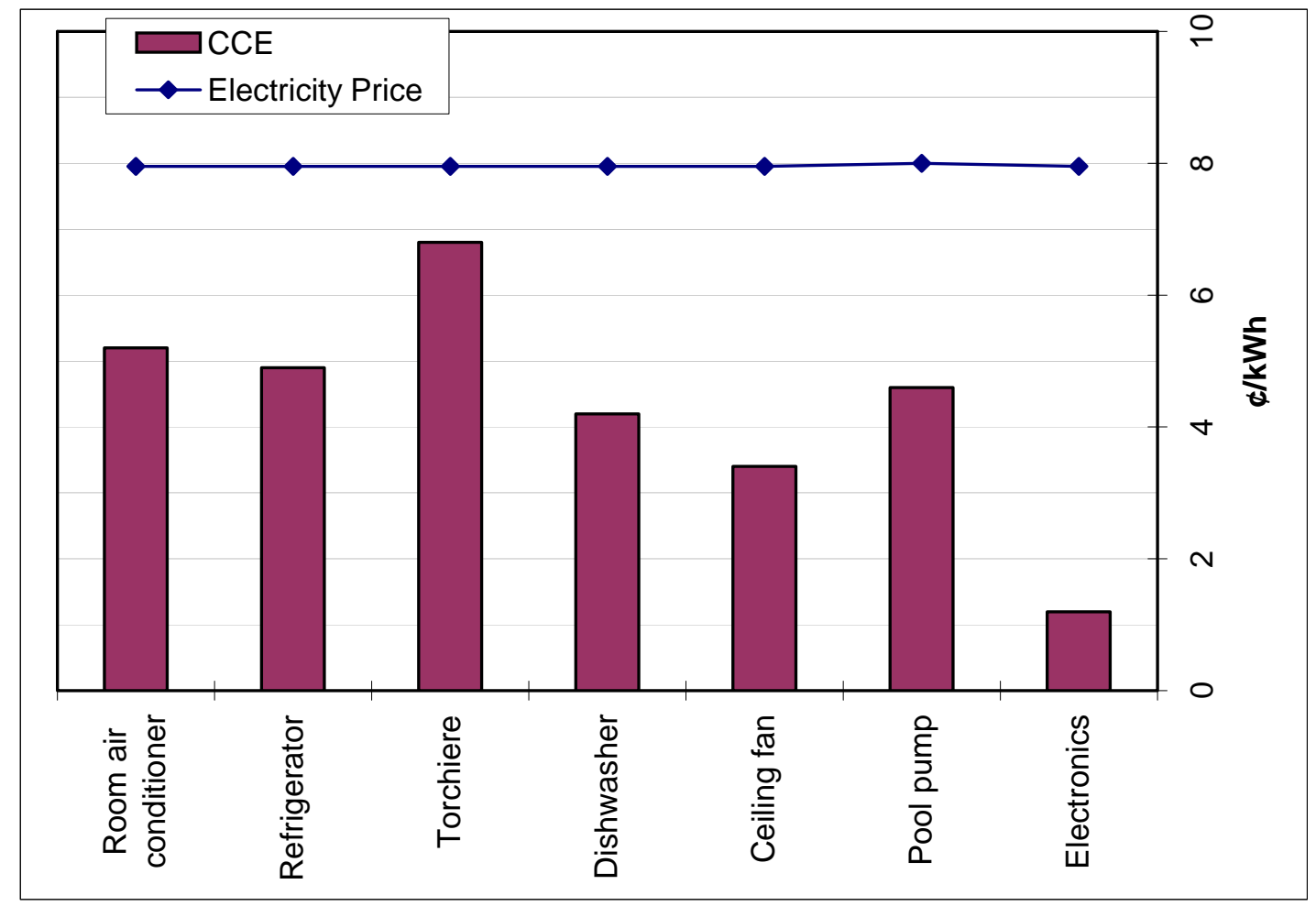

Figure 3. Comparison of Cost of Conserved Energy for 2010 Standards to Projected Electricity Price in the Residential Sector 


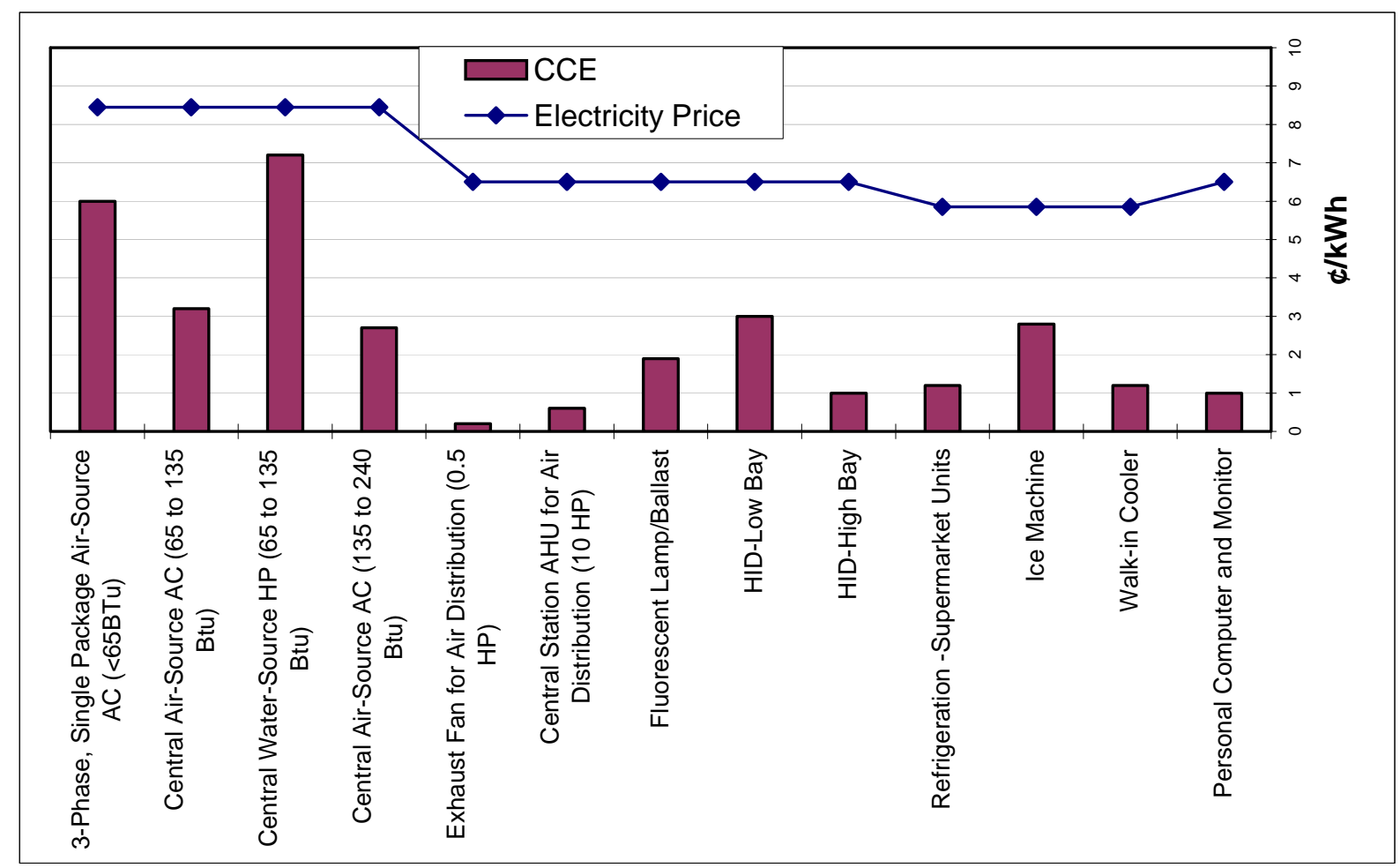

Figure 4: Comparison of Cost of Conserved Energy for Representative 2010 Standards to Marginal Electricity Price in the Commercial Sector

Our analysis considers the consumer perspective. Another perspective of interest is how the CCEs compare to the avoided costs of providing a unit of electricity and natural gas to consumers. In the short run, energy conservation mainly affects a utility's energy costs. In the long run, energy conservation may affect decisions about expanding generating and transmission and distribution capacity. ${ }^{8}$ The impact of energy efficiency standards on decisions about expanding generating and load distribution capacity varies across the U.S. On average, however, the impact of such standards is sufficiently large to have an impact on capacity expansion. This situation supports the use of long run avoided costs to measure the impacts of energy efficiency standards.

Determining the appropriate avoided costs at a national level for a future time period is not a simple exercise. One would expect the long run avoided costs of electricity and natural gas to be somewhat less than the retail prices we have used in this analysis. Given that the CCE for most of the considered standards is well below the forecast retail price, however, it is likely that most of the standards would be cost-effective compared to the long run avoided cost. 


\section{Estimation of National Impacts}

The Base Case (Business-as-usual) provides a reference against which we measure the potential impacts of upgraded standards. Our Base Case uses the reference energy consumption projections in AEO2004 through 2025 and extrapolated values thereafter. It includes all standards that have already been promulgated by DOE as of 2004. ${ }^{a}$ It implicitly assumes that new buildings meet recent State building codes. As a result of these and other factors, the Base Case shows ongoing efficiency improvement in each end-use.

The Upgraded Standards Case assumes upgraded and new standards take effect in 2010, and more stringent standards take effect in 2020 if they are cost-effective. The standards affect products installed from the effective date through 2030. We consider the impacts of standards over the lifetime of all products installed in the 2010-2030 period.

To estimate impacts of upgraded standards for each product, we first estimate the fraction of current energy consumption in each end use that is accounted for by the considered product. We assume this fraction remains constant over time. ${ }^{\mathrm{b}}$ We then use a stock model to estimate what share of the stock of each product in each future year consists of units installed after the standard effective date. Such products include replacements for retired products as well as products installed in new buildings. The stock model makes use of the estimated current stock, the mean lifetime of each product, a retirement function, and projected installations due to new construction of residential and commercial buildings. Projections of new construction are based on AEO 2004.

Appliances installed after the standard effective date represents those products potentially affected by standards. For the residential sector, we had data that allowed estimation of the share of the products in the Base Case that are more efficient than the upgraded standard, and thus would not be impacted by new or upgraded standards. We estimated these shares based on market statistics for high-efficiency products with an "Energy Star" designation. As similar data were not available for the commercial sector products, we assumed that all of the products installed after the standard effective date would potentially be affected by standards. In the Base Case, we assume that the "eligible" products utilize the baseline technology considered in the technology costefficiency analysis. Since some commercial sector products installed after 2010 are likely to have a higher efficiency than the baseline technology even without standards, our method leads to some over-estimation of energy savings from standards.

\footnotetext{
${ }^{\mathrm{a}}$ The base case includes standards with effective dates in the future, such as the revised standard for clothes washers that will take effect in 2007. It does not include standards that are still under consideration by DOE.

${ }^{\mathrm{b}}$ Ideally, one would model potential change in the share. Such analysis was not possible for this study.
} 
In the Upgraded Standards Case, we apply the percentage reduction in average annual energy consumption associated with the standard (relative to the baseline technology) to the share of Base Case energy consumption that is accounted for by products installed after the standard effective date. The result is the aggregate energy savings attributable to the standard.

For example, the 2010 standard for refrigerators results in 10\% reduction in the average annual energy consumption compared to the baseline technology. We estimated that $25 \%$ of the total new units purchased after 2010 would be at least as efficient as the upgraded 2010 standard. Thus, 75\% of the total new units purchased after 2010 would be affected by the standard. We assume that these units are the baseline technology. We calculate total annual energy savings by multiplying: (1) the $10 \%$ reduction in average annual energy consumption by (2) the average annual energy consumption of the baseline technology by (3) the number of eligible products installed in each year.

Appendix 4 provides further discussion of the accounting framework used to estimate national-level impacts. The approach used is obviously a simplification of a complex reality, and many of the assumptions are subject to uncertainty.

We express the annual electricity and natural gas savings from upgraded standards in total primary energy using annual primary-to-site energy factors based on $A E O 2004$. $^{\mathrm{c}}$

\section{Value of Energy Savings}

One way to measure the value of the energy savings due to standards is to consider the costs avoided by energy suppliers. In the short run, energy conservation mainly affects a utility's energy costs (though there may also be short-run avoided capacity costs). In the long run, energy conservation may affect decisions about expanding generating and transmission and distribution capacity.

The view that the long-run avoided utility cost is the appropriate measure for energy efficiency was actively discussed in the context of utility energy conservation programs, and various approaches for estimating it were debated for many years. Least-Cost Utility Planning, a handbook for public utility commissioners published by the National association of Regulatory Utility Commissioners, discusses several methods for measuring long-run avoided costs of conservation programs. ${ }^{8}$

The impact of energy efficiency standards on decisions about expanding generating and load distribution capacity varies across the U.S. On average, however, the impact of such standards is sufficiently large to have an impact on capacity expansion, which suggests that long run avoided utility costs are a more appropriate measure of the avoided cost associated with energy efficiency standards. Estimating such costs on a national level is difficult, however. For this report, we calculated the value of the energy savings

\footnotetext{
${ }^{\mathrm{c}}$ The AEO 2004 projections go through 2025. We extrapolated the past trends to estimate prices for later years.
} 
from new and upgraded standards by using the same energy prices as in the consumer impacts analysis. This value reflects the consumer perspective.

We calculated the Net Present Value (NPV) to consumers as the difference between the national operating cost savings due to the equipment standards and the increased national equipment costs associated with the standards. We expressed future costs and benefits in present (2004) value terms by using alternative national-level discount rates.

The 7\% discount rate is based on guidance issued by the Office of Management and Budget (OMB) in Circular No. A-94 (Revised), which states (section 8): "In general, public investments and regulations displace both private investment and consumption. ... Constant-dollar benefit-cost analyses of proposed investments and regulations should report net present value and other outcomes determined using a real discount rate of 7 percent. This rate approximates the marginal pretax rate of return on an average

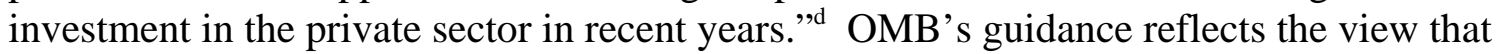
- from a national perspective - the opportunity cost of capital invested to improve appliance efficiency is best approximated by using the return on an average investment in the private sector. In DOE's analyses of the national economic impacts of equipment energy efficiency standards, it relies on the OMB guidance.

The OMB guidance notes that regulations may displace both private investment and consumption. Most estimates of the rate of return on consumption are on the order of 3 or 4 percent. ${ }^{9}$ In 2003 the OMB advised Federal agencies to use a 3\% discount rate to express the "social rate of time preference" when regulation primarily affects private consumption (e.g., through higher consumer prices for goods). ${ }^{e}$ Thus, we also apply a “consumption discount rate”of 3\%.

\section{Results}

Figures 5 and 6 show the cumulative primary energy savings and cumulative net present value due to new and upgraded efficiency standards by end use for the residential and commercial sectors. The values reflect the lifetime impacts from products installed in the 2010-2030 period. The largest energy savings are associated with standards for residential electronics products, but the estimate for this group of products is subject to a high degree of uncertainty. The next largest savings in the residential sector come from standards for electric water heaters and torchieres. Apart from electronics, the greatest savings come from standards for commercial refrigeration, followed by lighting and air conditioning.

The largest net present value comes from residential electronics products, but the caveat mentioned above applies here. Apart from residential electronics products, standards in the commercial sector yield more NPV than do those in the residential sector.

\footnotetext{
${ }^{\mathrm{d}}$ See http://www.whitehouse.gov/omb/circulars/a094/a094.html\#9.

${ }^{\text {e }}$ OMB, Circular A-4, Sept. 17, 2003, p. 33.
} 
Figure 5. Cumulative primary energy savings from upgraded standards for

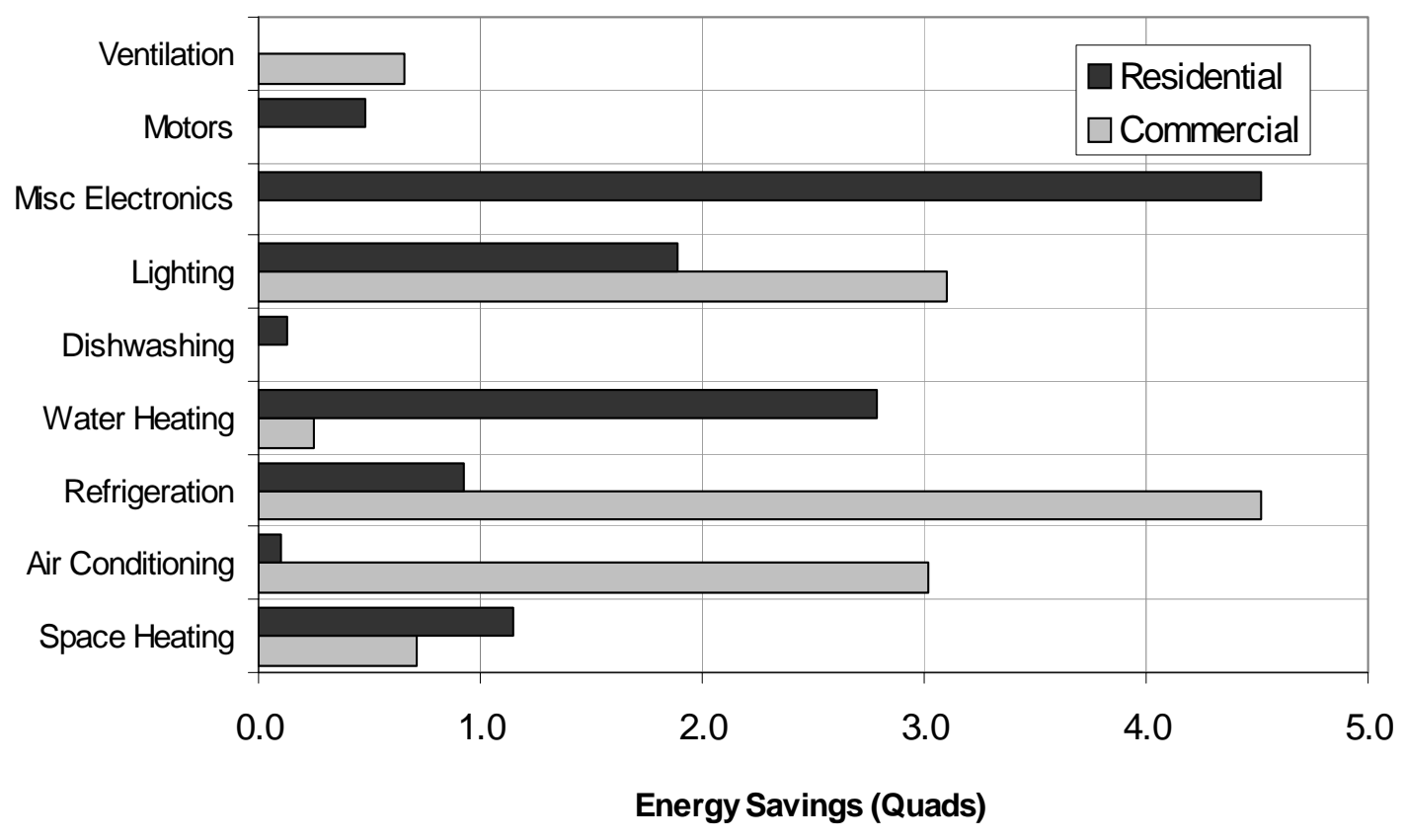

products installed in 2010-2030 period

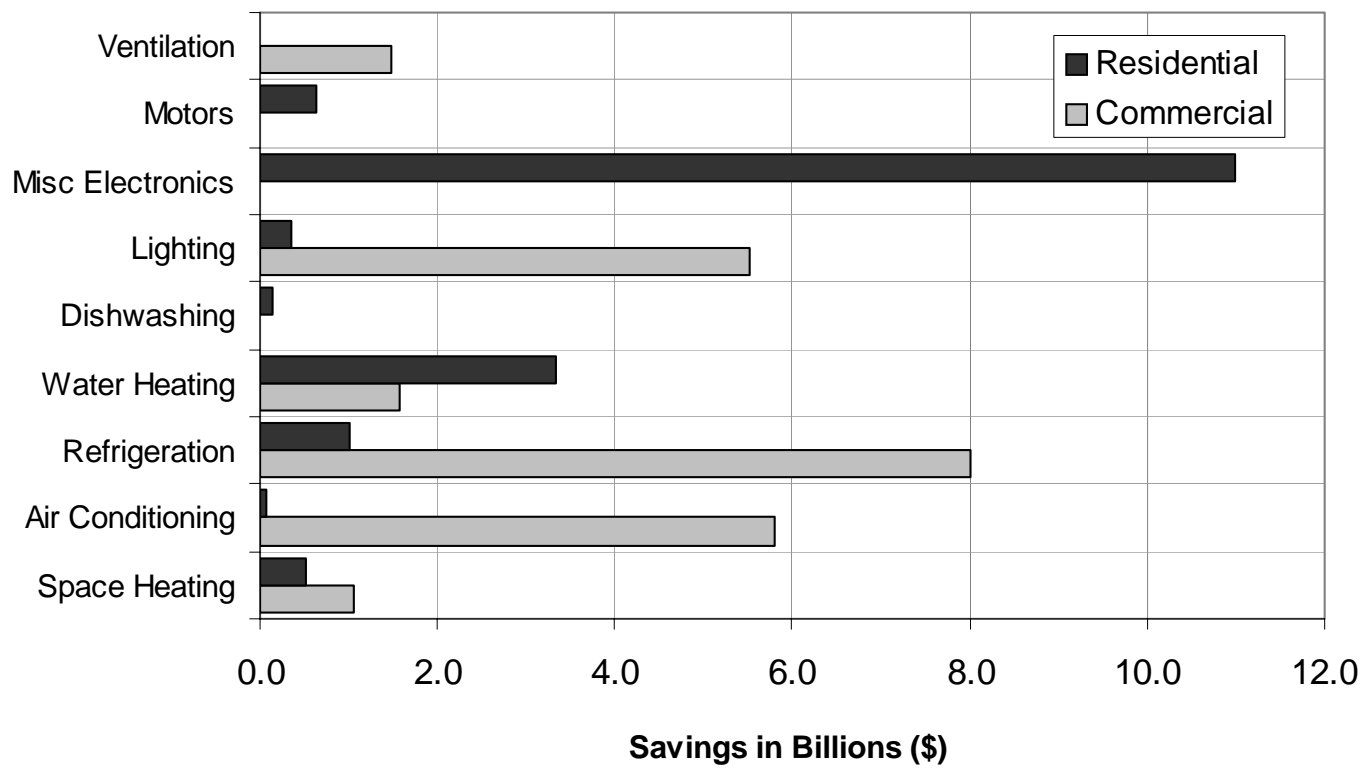

Figure 6. Net present value of consumer benefit from upgraded standards for products installed in $2010-2030$ period ( $7 \%$ discount rate)

In tabular form, Tables 7 and 8 show the cumulative primary energy savings and cumulative net present value due to upgraded equipment standards by end use for the residential and commercial sectors, respectively. The total cumulative energy savings 
amount to just under 26 quads. The total NPV is $\$ 42$ billion using a 7\% discount rate, but $\$ 104$ billion using 3\%. The commercial sector accounts for a greater share of the total energy savings and NPV than the residential sector.

Table 7: Residential Sector Energy Savings and Consumer Benefit for Products Installed in 2010-2030 Period

\begin{tabular}{|c|c|c|c|}
\hline \multirow{2}{*}{ End Use/Product } & \multirow{2}{*}{$\begin{array}{c}\text { Cumulative } \\
\text { Primary Energy } \\
\text { Savings (quads) }\end{array}$} & \multicolumn{2}{|c|}{ NPV of Consumer Benefit (billion \$) } \\
\hline & & $7 \%$ discount rate & $3 \%$ discount rate \\
\hline \multicolumn{4}{|l|}{ Space Heating } \\
\hline Gas furnace & 1.1 & 0.5 & 3.1 \\
\hline \multicolumn{4}{|l|}{ Air Conditioning } \\
\hline Room air conditioner & 0.10 & 0.08 & 0.30 \\
\hline \multicolumn{4}{|l|}{ Refrigeration } \\
\hline Refrigerator & 0.92 & 1.0 & 3.6 \\
\hline \multicolumn{4}{|l|}{ Lighting } \\
\hline Torchiere & 1.9 & 0.36 & 1.5 \\
\hline \multicolumn{4}{|l|}{ Water heating } \\
\hline Electric & 2.8 & 3.3 & 11.8 \\
\hline Dishwashing* & 0.13 & 0.13 & 0.35 \\
\hline Motors & 0.48 & 0.62 & 1.5 \\
\hline Electronics & 4.5 & 11.0 & 22.9 \\
\hline TOTAL & 12.0 & 17.0 & 45.1 \\
\hline
\end{tabular}

* Includes water heating savings derive from the higher-efficiency dishwasher, which uses less hot water. 
Table 8: Commercial Sector Energy Savings and Consumer Benefit for Products Installed in 2010-2030 Period

\begin{tabular}{|c|c|c|c|}
\hline \multirow{2}{*}{ End Use/Products } & \multirow{2}{*}{$\begin{array}{c}\text { Cumulative } \\
\text { Primary } \\
\text { Energy } \\
\text { Savings } \\
\text { (quads) } \\
\end{array}$} & \multicolumn{2}{|c|}{ NPV of Consumer Benefit (billion \$) } \\
\hline & & $7 \%$ discount rate & $3 \%$ discount rate \\
\hline \multicolumn{4}{|l|}{ Space Heating } \\
\hline Various & 0.71 & 1.1 & 2.7 \\
\hline \multicolumn{4}{|l|}{ Air Conditioning } \\
\hline Various & 3.0 & 5.8 & 14.0 \\
\hline \multicolumn{4}{|l|}{ Ventilation } \\
\hline Various & 0.66 & 1.5 & 3.2 \\
\hline \multicolumn{4}{|l|}{ Water Heating } \\
\hline Various & 0.25 & 1.6 & 3.2 \\
\hline \multicolumn{4}{|l|}{ Lighting } \\
\hline Various & 3.1 & 5.5 & 12.8 \\
\hline \multicolumn{4}{|l|}{\begin{tabular}{|l|} 
Refrigeration \\
\end{tabular}} \\
\hline Various & 4.5 & 8.0 & 16.6 \\
\hline Office Equipment & 1.6 & 3.7 & 6.0 \\
\hline TOTAL COMMERCIAL & 13.8 & 27.2 & 58.6 \\
\hline
\end{tabular}

\section{Conclusion}

This study estimated key national impacts of potential upgrades in energy efficiency standards for residential and commercial equipment. These impacts approximate the opportunity for national benefits that may be lost if energy efficiency standards for residential and commercial equipment are not upgraded and expanded from current levels.

The study used an analytical approach that is similar to the one used by the U.S. Department of Energy to set standard levels. Since it relies on much less data and uses simplified assumptions rather than the detailed formulations used in DOE's standardsetting process, the results of this analysis should be viewed as a first approximation of the impacts that would actually be achieved by new standards.

Our estimate of total cumulative energy savings from new and upgraded standards that would be effective in 2010-2030 amounts to just under 26 quads. The annual savings amount to one quad in 2015 and two quads in 2025. The largest energy savings are associated with standards for residential electronics products, but this estimate is subject to a high degree of uncertainty. Apart from electronics, the greatest savings come from standards for commercial refrigeration, followed by lighting and air conditioning. The 
next largest savings in the residential sector come from standards for electric water heaters and torchieres.

The total NPV is $\$ 42$ billion using a 7\% discount rate, but $\$ 104$ billion using 3\%. The largest net present value comes from residential electronics products, but the caveat mentioned above applies here. Apart from residential electronics products, standards in the commercial sector yield much more NPV than do those in the residential sector.

In assessing the results, the limitations of this study should be borne in mind. As mentioned in the introduction, this study relied on much less data and more simplified assumptions than does DOE's standard-setting process. Despite this caveat, our results suggest that national benefits from new and upgraded standards may be substantial. They also indicate that standards for currently-unregulated products would yield more benefits than upgrading minimum efficiency standards for products that already have them. The majority of those currently-unregulated products are in the commercial sector. 


\section{References}

1. Wiel, S. and J. E. McMahon, Energy Efficiency Labels and Standards: A Guidebook for Appliances, Equipment, and Lighting, 2001, Collaborative Labeling and Appliance Standards Program (CLASP). Washington, DC. (Table 2-1). Report No. LBNL-45387. < http://www.clasponline.org/index.php3>

2. Meyers, S., J. McMahon, M. McNeil, and X. Liu, Realized and Prospective Impacts of U.S. Energy Efficiency Standards for Residential Appliances, June 2002, 2002, Lawrence Berkeley National Laboratory. Berkeley, CA. Report No. LBNL-49504. <http://www-library.lbl.gov/docs/LBNL/495/04/PDF/LBNL-49504.pdf>

3. U.S. Department of Energy- Building Technologies Program, 2004. For technical documents on various products, see the website for DOE's Appliances and Commercial Equipment Standards Program. (Last accessed September 14, 2004). <http://www.eere.energy.gov/buildings/appliance_standards/>

4. Interlaboratory Working Group, Scenarios for a Clean Energy Future, November, 2000, Oak Ridge National Laboratory and Lawrence Berkeley National Laboratory. Oak Ridge, TN and Berkeley, CA. Report No. ORNL/CON-476 and LBNL-44029.

5. Newell, R. G., DRAFT Incorporation of Technological Learning into NEMS Building Modules, September, 2000, U.S. Department of Energy, Energy Information Administration. Washington, DC.

6. U.S. Department of Energy-Office of Building Technologies, Commercial Unitary Air Conditioners and Heat Pumps, Energy Conservation Standards Rulemaking, Life Cycle Cost Analysis Spreadsheet Model (Tariff-Based Electricity Prices), 2004. Washington, DC.

<http://www.eere.energy.gov/buildings/appliance_standards/commercial/ac_hp.ht $\underline{\mathrm{ml}} .>$

7. U.S. Department of Energy - Energy Information Administration, Annual Energy Outlook 2004: With Projections Through 2025, January, 2004. Washington, DC. Report No. DOE/EIA-0383(2004). <http://www.eia.doe.gov/oiaf/aeo>

8. Krause, F. and J. Eto, Least-Cost Utility Planning Handbook for Public Utility Commissioners. Volume 2 - The Demand Side: Conceptual and Methodological Issues, December, 1988, National Association of Regulatory Utility Commissioners. Washington, DC.

9. Arrow, K., A Comment on Cooper. The World Bank Research Observer, 2000. 15(2). 


\section{Appendix 1}

\section{Methods and Sources Used for the Appliance Cost-Efficiency Analysis}

\section{General Approach}

For each considered product, we estimated the incremental consumer cost of technologies providing higher energy efficiency relative to a specific baseline technology, as well as the associated reduction in annual energy use. This appendix describes the key inputs and results, and presents the sources for the input data.

For some of the products, we used the most common type as a proxy for the entire class. For example, for refrigerator-freezers, we used a top-mount auto-defrost refrigerator-freezer with $21.4 \mathrm{cu} . \mathrm{ft}$. adjusted volume as a proxy for the class.

The tables in this appendix present data for the technologies that were selected for the 2010 and 2020 standards. One summary statistic for each technology is the cost of conserved energy (CCE), which spreads the initial incremental cost over the lifetime of the equipment. Cost of conserved energy (non-discounted) for each product is given by:

where

$$
C C E=\frac{\Delta E C}{\sum_{1}^{L} \Delta O C}
$$

$$
\begin{array}{lll}
C C E & = & \text { Cost of Conserved Energy } \\
\triangle E C= & \text { Incremental Consumer Equipment Cost } \\
\triangle O C= & \text { Annual Consumer Operating Cost Savings } \\
L & = & \text { Equipment Lifetime }
\end{array}
$$

Calculation of a discounted CCE values requires application of a Present Worth Factor (PWF) to spread the initial incremental cost over the lifetime of the equipment. The PWF uses a discount rate to effectively amortize costs over time. We derived separate discount rates for residential and commercial consumers, as discussed in Appendix 3.

Another summary statistic is the life-cycle cost (LCC). The LCC for a piece of equipment includes the initial capital cost and the operating costs over an assumed lifetime, with the operating costs discounted to a present value. We calculated the LCC for each technology using the same discount rates as for the CCE calculation. 
The tables include installed costs, annual energy consumption and LCC for the baseline model of each technology, where available. For some technologies, only incremental costs and consumption were available; baseline data are not listed for these technologies.

For each considered product, we actually analyzed a number of technologies. Figures 1-4 provide examples of the range of technologies considered, and show how the consumer price and the LCC change with efficiency.

Figures 1 and 2. Price and Life-Cycle Cost Change vs. Efficiency for Commercial Central Air Conditioner, Water-Source HP $>65 \mathrm{kBtu} / \mathrm{h}$ and $<135 \mathrm{kBtu} / \mathrm{h}$
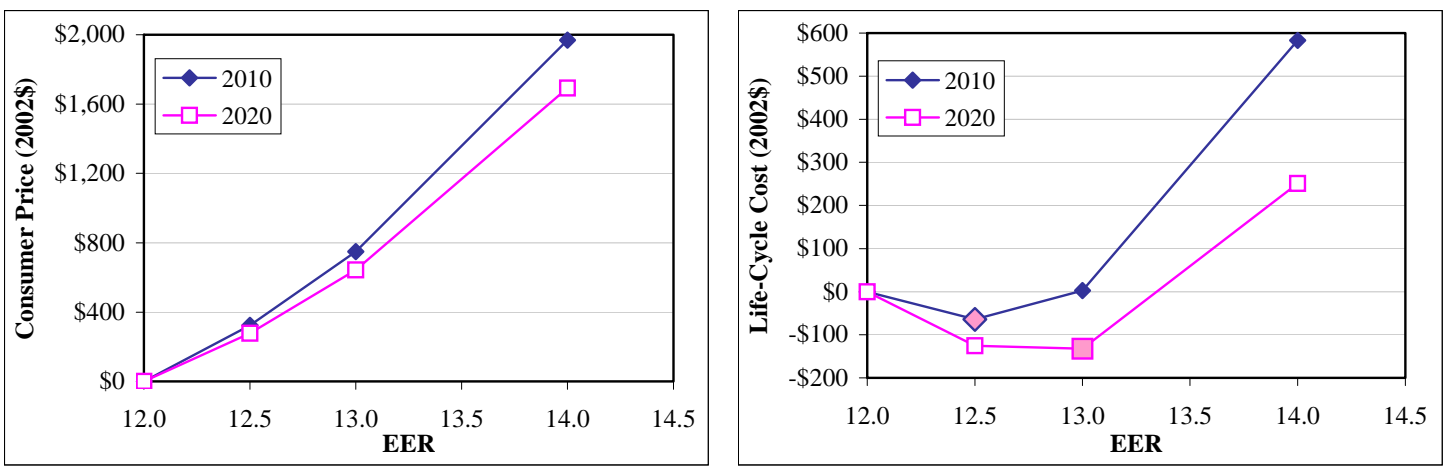

Figures 3 and 4. Price and Life-Cycle Cost Change vs. Efficiency for Top-Mount Auto Defrost Refrigerator-Freezer
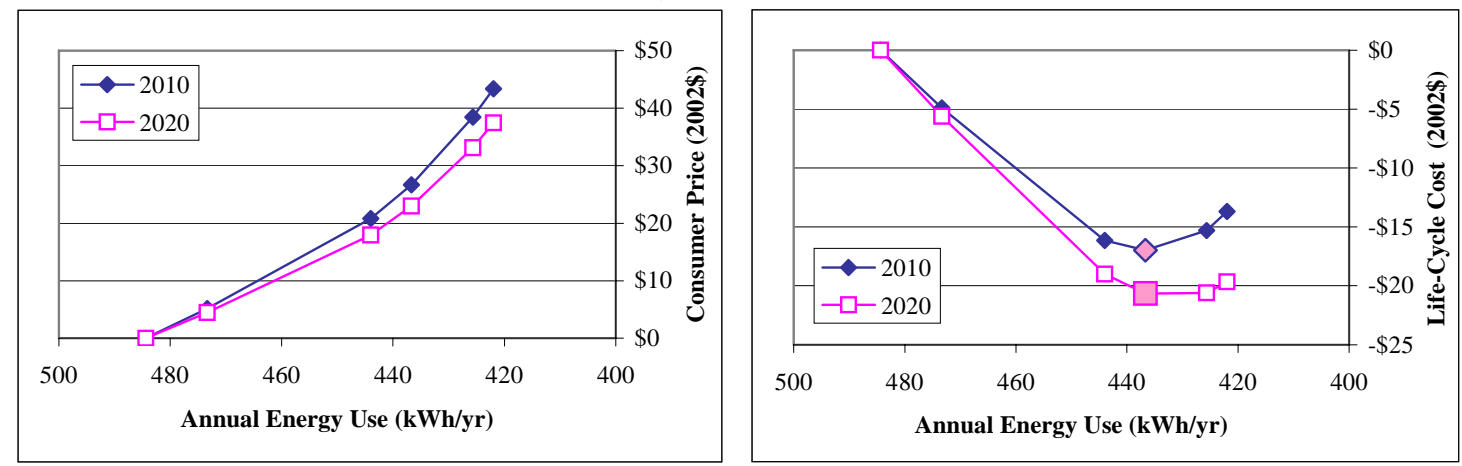


\section{Residential Sector Products}

Sector: Residential

End Use: Natural Gas and LPG Space Heating

Product: Gas Furnace

Lifetime (years): 20

Baseline Technology: 80\% Annual Fuel Utilization Efficiency (AFUE)

Baseline Installed Cost in 2010: \$1,792

Baseline Annual Energy Consumption: 64.9 MMBtu

Baseline Life Cycle Cost in 2010: \$8,214

\begin{tabular}{|l|c|c|}
\hline & $\begin{array}{c}\text { Technology for 2010 } \\
\text { Standard }\end{array}$ & $\begin{array}{c}\text { Technology for 2020 } \\
\text { Standard }\end{array}$ \\
\hline Description & $\begin{array}{c}\text { 81\% AFUE using two-stage } \\
\text { modulation }\end{array}$ & Same as 2010 \\
\hline Increase in installed cost* (\$) & $\$ 155$ & $\$ 136$ \\
\hline Annual energy savings* (MMBtu) & 2.1 & 2.1 \\
\hline CCE (\$MMBtu) & $\$ 6.20$ & $\$ 5.40$ \\
\hline Decrease in LCC* $(\$)$ & $\$ 41$ & $\$ 75$ \\
\hline
\end{tabular}

* Relative to baseline technology.

Notes:

Incremental costs for LPG equipment are assumed equivalent to those for natural gas furnaces, since most manufacturers market an LPG furnace of nearly identical design to their natural gas models. The annual savings, CCE, and LCC change given are specific to natural gas furnaces.

$81 \%$ 2-stage modulation furnace uses Category I venting system.

\section{Source(s):}

House Heating load - RECS97.

Other inputs - DOE Residential Furnaces and Boilers Proposed Rulemaking, Preliminary Engineering Analysis September 22, 2002

http://www.eere.energy.gov/buildings/appliance standards/residential/furnaces boilers.html

Sector: Residential

End Use: Air conditioning

Product: Room air conditioner

Lifetime (years): 12.5

Baseline Technology: 8,000-13,999 Btu/hr, with louvered sides, without reversing valve, 9.85 EER

Baseline Installed Cost in 2010: \$482

Baseline Annual Energy Consumption: $657 \mathrm{kWh}$

Baseline Life Cycle Cost in 2010: \$930

\begin{tabular}{|l|c|c|}
\hline & $\begin{array}{c}\text { Technology for 2010 } \\
\text { Standard }\end{array}$ & $\begin{array}{c}\text { Technology for 2020 } \\
\text { Standard }\end{array}$ \\
\hline Description & 10.11 EER & Same as 2010 \\
\hline Increase in installed cost* $(\$)$ & $\$ 8$ & $\$ 7$ \\
\hline Annual energy savings* $(\mathrm{kWh})$ & 17 & 17 \\
\hline CCE $(\$ / \mathrm{kWh})$ & 5.2 & 4.5 \\
\hline Decrease in LCC* $(\$)$ & $\$ 4$ & $\$ 5$ \\
\hline
\end{tabular}

* Relative to baseline technology.

Source(s): U.S. Department of Energy (DOE)-Office of Codes and Standards. 1997. "Technical Support Document for Energy Conservation Standards for Room Air Conditioners, Volume 2 - Detailed Analysis of Efficiency Levels (Docket Numbers EE-RM-90-201 \& EM-RM-93-801-RAC).” Washington, DC. September, 1997. 
Sector: Residential

End Use: Refrigeration

Product: Refrigerator-freezer

Lifetime (years): 19

Baseline Technology: Top-mount auto-defrost refrigerator-freezer, 21.4 cu.ft. adjusted volume, using 484 $\mathrm{kWh} /$ year

Baseline Installed Cost in 2010: \$603

Baseline Annual Energy Consumption: $484 \mathrm{kWh}$

Baseline Life Cycle Cost in 2010: \$1,046

\begin{tabular}{|l|c|c|}
\hline & $\begin{array}{c}\text { Technology for 2010 } \\
\text { Standard }\end{array}$ & $\begin{array}{c}\text { Technology for 2020 } \\
\text { Standard }\end{array}$ \\
\hline Description & $437 \mathrm{kWh} / \mathrm{yr}$ & Same as 2010 \\
\hline Increase in installed cost* $(\$)$ & $\$ 27$ & $\$ 23$ \\
\hline Annual energy savings* $(\mathrm{kWh})$ & 48 & 48 \\
\hline CCE $(\$ / \mathrm{kWh})$ & 4.9 & 4.2 \\
\hline Decrease in LCC* $(\$)$ & $\$ 17$ & $\$ 21$ \\
\hline
\end{tabular}

* Relative to baseline technology.

Notes:

Source(s): U.S. Department of Energy (DOE)-Office of Codes and Standards. 1995. "Technical Support Document: Energy Efficiency Standards for Consumer Products: Refrigerators, Refrigerator-Freezers, \& Freezers.” Washington, DC. DOE/EE-0064. July, 1995.

Sector: Residential

End Use: Water heating

Product: Electric water heater

Lifetime (years): 14

Baseline Technology: 90 Energy Factor (EF), 50 gallon nominal

Baseline Installed Cost in 2010: \$491

Baseline Annual Energy Consumption: $3275 \mathrm{kWh}$

Baseline Life Cycle Cost in 2020: \$1,046

\begin{tabular}{|l|c|c|}
\hline & Technology for 2010 Standard & Technology for 2020 Standard \\
\hline Description & None & Heat pump \\
\hline Increase in installed cost* $(\$)$ & N/A & $\$ 753$ \\
\hline Annual energy savings* $(\mathrm{kWh})$ & N/A & 2097 \\
\hline CCE $(\$ / \mathrm{kWh})$ & N/A & 3.9 \\
\hline Decrease in LCC* $(\$)$ & N/A & $\$ 865$ \\
\hline
\end{tabular}

* Relative to baseline technology.

Notes:

Heat pump water heater price - D \& R International - ENERGY STAR Labeling Potential for Water Heaters - DOE April 4, 2003.

Source(s): U.S. Department of Energy (DOE)-Office of Codes and Standards. 2001. "Technical Support Document: Energy Efficiency Standards for Consumer Products: Residential Water Heaters.” Washington, DC. January, 2001. 
Sector: Residential

End Use: Dishwashing

Product: Dishwasher

Lifetime (years): 12.6

Baseline Technology: $2.14 \mathrm{kWh} /$ cycle

Baseline Equipment Cost in 2010: \$332

Baseline Annual Energy Consumption: 535 kWh

Baseline Life Cycle Cost in 2010: \$620

\begin{tabular}{|l|c|c|}
\hline & $\begin{array}{c}\text { Technology for 2010 } \\
\text { Standard }\end{array}$ & $\begin{array}{c}\text { Technology for 2020 } \\
\text { Standard }\end{array}$ \\
\hline Description & $1.96 \mathrm{kWh} /$ cycle & Same as 2010 \\
\hline Increase in consumer first cost* $(\$)$ & $\$ 17$ & $\$ 15$ \\
\hline Annual energy savings* $(\mathrm{kWh})$ & 52 & 32 \\
\hline CCE $(\$ / \mathrm{kWh})$ & 3.6 & 3.1 \\
\hline Decrease in LCC* $(\$)$ & $\$ 8$ & $\$ 10$ \\
\hline
\end{tabular}

* Relative to baseline technology.

\section{Notes:}

Annual energy consumption and savings includes associated water heater energy use assuming gas water heater efficiency of $75 \%$ and market share of $55 \%$. Although we present the energy in $\mathrm{kWh}$, the values include gas and electricity use. The CCE includes the energy savings from reduced water heating.

Source: Biermayer, P. Energy and Water Saving Potential of Dishwashers and Clothes Washers: An Update. 1996 ACEEE Summer Study on Building Energy Efficiency.

Sector: Residential

End Use: Lighting

Product: Torchiere

Lifetime (years): 4.5

Baseline Technology: Incandescent lamp

Baseline Equipment Cost in 2010: \$17

Baseline Annual Energy Consumption: 209 kWh

Baseline Life Cycle Cost in 2010: \$81

\begin{tabular}{|l|c|c|}
\hline & $\begin{array}{c}\text { Technology for 2010 } \\
\text { Standard }\end{array}$ & Technology for 2020 Standard \\
\hline Description & Fluorescent lamp & Same as 2010 \\
\hline Increase in consumer first cost* $(\$)$ & $\$ 30$ & $\$ 26$ \\
\hline Annual energy savings* $(\mathrm{kWh})$ & 123 & 123 \\
\hline CCE $(\$ / \mathrm{kWh})$ & 6.8 & 5.9 \\
\hline Decrease in LCC* $(\$)$ & $\$ 6$ & $\$ 10$ \\
\hline
\end{tabular}

* Relative to baseline technology.

Notes:

Base case assumes that halogen lamps are phased out by 2010. Incremental cost includes purchase of a replacement CFL and replacement of incandescent lamps during the lifetime of the torchiere.

Source(s): Unpublished analysis done by LNBL in 2003. Data inputs were from industry sources. 
Sector: Residential

End Use: Other Electricity - Electronics

Product: Audio

Lifetime (years): 7

Baseline Technology: 3 W Standby Rack/Component System and 10 W Standby Compact System Baseline Annual Energy Consumption: $121 \mathrm{kWh}$

\begin{tabular}{|l|c|c|}
\hline & $\begin{array}{c}\text { Technology for 2010 } \\
\text { Standard }\end{array}$ & $\begin{array}{c}\text { Technology for 2020 } \\
\text { Standard }\end{array}$ \\
\hline Description & 1 W Standby & Same as 2010 \\
\hline Increase in consumer first cost* $(\$)$ & $\$ 2$ & $\$ 2$ \\
\hline Annual energy savings* $(\mathrm{kWh})$ & 30 & 30 \\
\hline CCE $(\$ / \mathrm{kWh})$ & 1.2 & 1.0 \\
\hline Decrease in LCC* $(\$)$ & $\$ 12$ & $\$ 12$ \\
\hline
\end{tabular}

* Relative to baseline technology.

\section{Notes:}

The values given are stock-weighted averages for rack/component and compact audio systems. Incremental equipment cost of \$2 is from Clean Energy Futures report - assumes that most savings come from circuit redesign during the normal design phase (at negligible cost) plus an improved power supply.

Audio products included account for an estimated 7\% of energy use in Other Electricity category.

Source(s): Usage, power, equipment lifetime and shipments from Rosen and Meier - "Energy Use of Home Audio Products in the U.S.”, LBNL-43468. Stock quantities are from DOE FY 2005 Preliminary Priority-Setting Summary Report, Appendix A: FY 2005 Technical Support Document.

Sector: Residential

End Use: Other Electricity - Electronics

Product: Settop Boxes

Lifetime (years): 10

Baseline Technology: Current Practice Standby Power Baseline Annual Energy Consumption: $184 \mathrm{kWh}$

\begin{tabular}{|l|c|c|}
\hline & $\begin{array}{c}\text { Technology for 2010 } \\
\text { Standard }\end{array}$ & Technology for 2020 Standard \\
\hline Description & 7 W Standby & Same as 2010 \\
\hline Increase in consumer first cost* $(\$)$ & $\$ 2$ & $\$ 2$ \\
\hline Annual energy savings* $(\mathrm{kWh})$ & 95 & 95 \\
\hline CCE $(\$ / \mathrm{kWh})$ & 0.3 & 0.2 \\
\hline Decrease in LCC* $(\$)$ & $\$ 55$ & $\$ 55$ \\
\hline
\end{tabular}

* Relative to baseline technology.

Notes:

The values given are shipment-weighted averages over digital and wireless settop boxes. Analog settop boxes are assumed to be phased out before 2010. Incremental equipment cost of \$2 is from Clean Energy Futures report assumes that most savings come from circuit redesign during the normal design phase (at negligible cost) plus an improved power supply.

Product accounts for estimated 8\% of energy use in Other Electricity category.

Source(s): Usage, power, equipment lifetime and shipments from Rosen et al (2001), "Energy Use of Set-top boxes and Telephone Products in the U.S.," LBNL-45305. Stock quantities are from DOE FY 2005 Preliminary PrioritySetting Summary Report, Appendix A: FY 2005 Technical Support Document. 
Sector: Residential

End Use: Other Electricity - Electronics

Product: Telephony

Lifetime (years): 8

Baseline Technology: 3W Standby Power

Baseline Annual Energy Consumption: 31 kWh

\begin{tabular}{|l|c|c|}
\hline & $\begin{array}{c}\text { Technology for 2010 } \\
\text { Standard }\end{array}$ & $\begin{array}{c}\text { Technology for 2020 } \\
\text { Standard }\end{array}$ \\
\hline Description & 1W Standby Power & Same as 2010 \\
\hline Increase in consumer first cost* $(\$)$ & $\$ 2$ & $\$ 2$ \\
\hline Annual energy savings* $(\mathrm{kWh})$ & 8 & 8 \\
\hline CCE $(\$ / \mathrm{kWh})$ & 4.0 & 3.5 \\
\hline Decrease in LCC* $(\$)$ & $\$ 2$ & $\$ 2$ \\
\hline
\end{tabular}

* Relative to baseline technology.

Notes:

The values given are averages over answering machines and cordless phones. Incremental equipment cost of \$2 from the Clean Energy Futures report - assumes that most savings come from circuit redesign during the normal design phase (at negligible cost) plus an improved power supply.

Product accounts for estimated 3.1\% of energy use in Other Electricity category.

Sources: Energy consumption from Sanchez et al (1998), "Miscellaneous Electricity Use in U.S. Homes”, LBNL40295. Equipment lifetime is from Appliance, September 1998 (average of answering machine and cordless phone)

Sector: Residential

End Use: Other Electricity - Electronics

Product: Microwave Oven

Lifetime (years): 12

Baseline Technology: 3W Standby Power Baseline Annual Energy Consumption: 120 kWh

\begin{tabular}{|l|c|c|}
\hline & Technology for 2010 Standard & Technology for 2020 Standard \\
\hline Description & 1W Standby Power & Same as 2010 \\
\hline Increase in consumer first cost* $(\$)$ & $\$ 2$ & 81 \\
\hline Annual energy savings* $(\mathrm{kWh})$ & 81 & 0.2 \\
\hline CCE $(\$ / \mathrm{kWh})$ & 0.3 & $\$ 54$ \\
\hline Decrease in LCC* $(\$)$ & $\$ 53$ & \\
\hline
\end{tabular}

* Relative to baseline technology.

\section{Notes:}

Incremental equipment cost of \$2 is from Clean Energy Futures report - assumes that most savings come from circuit redesign during the normal design phase (at negligible cost) plus an improved power supply.

Product accounts for estimated $1.9 \%$ of energy use in Other Electricity category.

Sources: Energy consumption is from Sanchez et al. (1998), “Miscellaneous Electricity Use in U.S. Homes”, LBNL-40295. Equipment lifetime is from Appliance, September 1998. 
Sector: Residential

End Use: Other Electricity - Electronics

Product: Miscellaneous Electronics

Lifetime (years): 7

Baseline Technology: Current Practice Standby Power

Baseline Annual Energy Consumption: $42 \mathrm{kWh}$

\begin{tabular}{|l|c|c|}
\hline & $\begin{array}{c}\text { Technology for 2010 } \\
\text { Standard }\end{array}$ & $\begin{array}{c}\text { Technology for 2020 } \\
\text { Standard }\end{array}$ \\
\hline Description & 1W Standby Power & Same as 2010 \\
\hline Increase in consumer first cost* $(\$)$ & $\$ 2$ & $\$ 2$ \\
\hline Annual energy savings* $(\mathrm{kWh})$ & 24 & 24 \\
\hline CCE $(\mathrm{k} / \mathrm{kWh})$ & 1.5 & 1.3 \\
\hline Decrease in LCC* $(\$)$ & $\$ 9$ & $\$ 9$ \\
\hline
\end{tabular}

* Relative to baseline technology.

Notes:

The values given are weighted averages over battery chargers, shavers, electric toothbrushes, hand-held rechargeables, garage door openers, doorbells, security systems, modems, power strips and timers. Weighting is by estimated total national electricity consumption of each product. Incremental equipment cost of $\$ 2$ is from the Clean Energy Futures report - assumes that most savings come from circuit redesign during the normal design phase (at negligible cost) plus an improved power supply.

Products account for estimated 6.1\% of energy use in Other Electricity category.

Sources: Energy consumption is from Sanchez et al (1998), "Miscellaneous Electricity Use in U.S. Homes”, LBNL-40295. Equipment lifetime is average over included appliances from Appliance, September 1998.

Sector: Residential

End Use: Other Electricity - Motors

Product: Ceiling Fan

Lifetime (years): 15

Baseline Technology: Typical new fan motor efficiency

Baseline Annual Energy Consumption: 164 kWh

\begin{tabular}{|l|c|c|}
\hline & $\begin{array}{c}\text { Technology for 2010 } \\
\text { Standard }\end{array}$ & Technology for 2020 Standard \\
\hline Description & Energy Star Fan & Same as 2010 \\
\hline Increase in consumer first cost* $(\$)$ & $\$ 10$ & $\$ 9$ \\
\hline Annual energy savings* $(\mathrm{kWh})$ & 30 & 30 \\
\hline CCE $(\mathbf{\$} / \mathrm{kWh})$ & 3.4 & 2.9 \\
\hline Decrease in LCC* $(\$)$ & $\$ 14$ & $\$ 15$ \\
\hline
\end{tabular}

* Relative to baseline technology.

\section{Notes:}

Energy savings are from higher motor efficiency only.

Product accounts for estimated 4.6\% of energy use in Other Electricity category.

Source(s): DOE FY 2005 Preliminary Priority-Setting Summary Report, Appendix A: FY 2005 Technical Support Document. Incremental cost is from Clean Energy Futures report. Equipment lifetime is from Appliance, September 1998. 
Sector: Residential

End Use: Other Electricity - Motors

Product: Pool Pump

Lifetime (years): 10

Baseline Technology: Single-speed pump motor Baseline Annual Energy Consumption: 725 kWh

\begin{tabular}{|l|c|c|}
\hline & $\begin{array}{c}\text { Technology for 2010 } \\
\text { Standard }\end{array}$ & Technology for 2020 Standard \\
\hline Description & Dual-speed motor & Same as 2010 \\
\hline Increase in consumer first cost* $(\$)$ & $\$ 100$ & $\$ 86$ \\
\hline Annual energy savings* $(\mathrm{kWh})$ & 363 & 363 \\
\hline CCE $(\mathbf{\$} / \mathrm{kWh})$ & 3.7 & 3.2 \\
\hline Decrease in LCC* $(\$)$ & $\$ 116$ & $\$ 130$ \\
\hline
\end{tabular}

* Relative to baseline technology.

Product accounts for estimated $4.3 \%$ of energy use in Other Electricity category.

Source(s): Baseline energy consumption is from Department of Energy, Office of Building Research and Standards - 2002 Priority Setting for New Products, October 2001. Equipment lifetime, standards energy savings, and incremental cost are from Pacific Gas and Electric Company - Analysis of Standards Options for Residential Pool Pumps, Motors and Controls, May 2004. 


\section{Commercial Sector Products}

Note: All data given for commercial floor space are from EIA's 1999 Commercial Building Energy Consumption Survey.

Sector: Commercial

End Use: Space Heating

Product: Packaged Boiler, Gas-Fired, Hot Water (400 kBtu/hr)

Lifetime (years): 30

Baseline Technology: 75\% thermal efficiency

Baseline Installed Cost in 2010: \$4,886

Baseline Annual Energy Consumption: 408 MMBtu

Baseline Life Cycle Cost in 2010: \$41,867

\begin{tabular}{|l|c|c|}
\hline & Technology for 2010 Standard & Technology for 2020 Standard \\
\hline Description & 79\% thermal efficiency & Same as 2010 \\
\hline Increase in installed cost* (\$) & $\$ 291$ & $\$ 250$ \\
\hline Annual energy savings* (MMBtu) & 25.7 & 25.7 \\
\hline CCE $(\$ / M M B t u)$ & $\$ 1.03$ & $\$ 0.89$ \\
\hline Decrease in LCC* $(\$)$ & $\$ 1581$ & $\$ 1811$ \\
\hline
\end{tabular}

* Relative to baseline technology.

Notes: This product accounts for about $7 \%$ of the furnaces and boiler market for commercial space heating and covers about $11 \%$ of the commercial floor space heating.

Source(s): U.S. Department of Energy (DOE)-Office of Energy Efficiency and Renewable Energy. 2000.

"Screening Analysis for EPACT-Covered Commercial HVAC and Water-Heating Equipment, Volume 1 - Main

Report and Volume 2 - Appendix Material.” Washington, DC. April, 2000. Table 2.4, Table 3.8, Appendix D3-D80. 
Sector: Commercial

End Use: Space Heating

Product: Packaged Boiler, Gas-Fired, Hot Water (800 kBtu/hr)

Lifetime (years): 30

Baseline Technology: 75\% thermal efficiency

Baseline Installed Cost in 2010: \$6,926

Baseline Annual Energy Consumption: 1016 MMBtu

Baseline Life Cycle Cost in 2010: \$80,885

\begin{tabular}{|l|c|c|}
\hline & $\begin{array}{c}\text { Technology for 2010 } \\
\text { Standard }\end{array}$ & $\begin{array}{c}\text { Technology for 2020 } \\
\text { Standard }\end{array}$ \\
\hline Description & $78 \%$ thermal efficiency & $88 \%$ thermal efficiency \\
\hline Increase in installed cost* (\$) & $\$ 1405$ & $\$ 8175$ \\
\hline Annual energy savings* (MMBtu) & 39.1 & 150.0 \\
\hline CCE $(\$$ MMBtu) & $\$ 3.28$ & $\$ 4.97$ \\
\hline Decrease in LCC* $(\$)$ & $\$ 1439$ & $\$ 3853$ \\
\hline
\end{tabular}

* Relative to baseline technology.

Notes: This product accounts for about $7 \%$ of the furnaces and boiler market for commercial space heating and covers about $12 \%$ of the commercial floor space heating.

Source(s): U.S. Department of Energy (DOE)-Office of Energy Efficiency and Renewable Energy. 2000.

"Screening Analysis for EPACT-Covered Commercial HVAC and Water-Heating Equipment, Volume 1 - Main Report and Volume 2 - Appendix Material.” Washington, DC. April, 2000. Table 2.4, Table 3.8, Appendix D3-D80.

Sector: Commercial

End Use: Space Heating

Product: Packaged Boiler, Gas-Fired, Hot Water (1500 kBtu/hr)

Lifetime (years): 30

Baseline Technology: 75\% thermal efficiency

Baseline Installed Cost in 2010: \$10,458

Baseline Annual Energy Consumption: 1904 MMBtu

Baseline Life Cycle Cost in 2010: \$149,133

\begin{tabular}{|l|c|c|}
\hline & $\begin{array}{c}\text { Technology for 2010 } \\
\text { Standard }\end{array}$ & $\begin{array}{c}\text { Technology for 2020 } \\
\text { Standard }\end{array}$ \\
\hline Description & $88 \%$ thermal efficiency & Same as 2010 \\
\hline Increase in installed cost* $(\$)$ & $\$ 8354$ & $\$ 7182$ \\
\hline Annual energy savings* $(\mathrm{MMBtu})$ & 281.3 & 281.3 \\
\hline CCE $(\$$ MMBtu) & $\$ 2.71$ & $\$ 2.33$ \\
\hline Decrease in LCC* $(\$)$ & $\$ 12,132$ & $\$ 15,371$ \\
\hline
\end{tabular}

* Relative to baseline technology.

Notes: This product accounts for about $1 \%$ of the furnaces and boiler market for commercial space heating and covers about $2 \%$ of the commercial floor space heating.

Source(s): U.S. Department of Energy (DOE)-Office of Energy Efficiency and Renewable Energy. 2000.

"Screening Analysis for EPACT-Covered Commercial HVAC and Water-Heating Equipment, Volume 1 - Main Report and Volume 2 - Appendix Material.” Washington, DC. April, 2000. Table 2.4, Table 3.8, Appendix D3-D80. 
Sector: Commercial

End Use: Space Heating

Product: Packaged Boilers, Gas-Fired, Hot Water (3000 kBtu/hr)

Lifetime (years): 30

Baseline Technology: 75\% thermal efficiency

Baseline Installed Cost in 2010: \$16,894

Baseline Annual Energy Consumption: 3809 kBtu

Baseline Life Cycle Cost in 2010: \$294,243

\begin{tabular}{|l|c|c|}
\hline & $\begin{array}{c}\text { Technology for 2010 } \\
\text { Standard }\end{array}$ & $\begin{array}{c}\text { Technology for 2020 } \\
\text { Standard }\end{array}$ \\
\hline Description & $88 \%$ thermal efficiency & Same as 2010 \\
\hline Increase in installed cost* $(\$)$ & $\$ 10,136$ & $\$ 8714$ \\
\hline Annual energy savings* (MMBtu) & 562.7 & 562.7 \\
\hline CCE (\$/MMBtu) & $\$ 1.64$ & $\$ 1.41$ \\
\hline Decrease in LCC* $(\$)$ & $\$ 30,836$ & $\$ 36,392$ \\
\hline
\end{tabular}

* Relative to baseline technology.

Notes: This product accounts for about $0.4 \%$ of the furnaces and boiler market for commercial space heating and covers about $0.7 \%$ of the commercial floor space heating.

Source(s): U.S. Department of Energy (DOE)-Office of Energy Efficiency and Renewable Energy. 2000.

"Screening Analysis for EPACT-Covered Commercial HVAC and Water-Heating Equipment, Volume 1 - Main

Report and Volume 2 - Appendix Material.” Washington, DC. April, 2000. Table 2.4, Table 3.8, Appendix D3-D80.

Sector: Commercial

End Use: Space Heating

Product: Packaged Boiler, Gas-Fired, Steam (400 kBtu/hr)

Lifetime (years): 30

Baseline Technology: 72\% thermal efficiency

Baseline Installed Cost in 2010: \$6,715

Baseline Annual Energy Consumption: 529 MMBtu

Baseline Life Cycle Cost in 2010: \$45,237

\begin{tabular}{|l|c|c|}
\hline & Technology for 2010 Standard & Technology for 2020 Standard \\
\hline Description & $76 \%$ thermal efficiency & Same as 2010 \\
\hline Increase in installed cost* $(\$)$ & $\$ 1008$ & $\$ 866$ \\
\hline Annual energy savings* $(\mathrm{MMBtu})$ & 27.8 & 27.8 \\
\hline CCE $(\$$ MMBtu) & $\$ 3.30$ & $\$ 2.84$ \\
\hline Decrease in LCC* $(\$)$ & $\$ 1020$ & $\$ 1366$ \\
\hline
\end{tabular}

* Relative to baseline technology.

Notes: This product accounts for about 3\% of the furnaces and boiler market for commercial space heating and covers about $5 \%$ of the commercial floor space heating.

Source(s): U.S. Department of Energy (DOE)-Office of Energy Efficiency and Renewable Energy. 2000.

"Screening Analysis for EPACT-Covered Commercial HVAC and Water-Heating Equipment, Volume 1 - Main Report and Volume 2 - Appendix Material.” Washington, DC. April, 2000. Table 2.4, Table 3.8, Appendix D3-D80. 
Sector: Commercial

End Use: Space Heating

Product: Packaged Boiler, Gas-Fired, Steam (800 kBtu/hr)

Lifetime (years): 30

Baseline Technology: 72\% thermal efficiency

Baseline Installed Cost in 2010: \$8,916

Baseline Annual Energy Consumption: 1058 MMBtu

Baseline Life Cycle Cost in 2010: \$85,957

\begin{tabular}{|l|c|c|}
\hline & $\begin{array}{c}\text { Technology for 2010 } \\
\text { Standard }\end{array}$ & $\begin{array}{c}\text { Technology for 2020 } \\
\text { Standard }\end{array}$ \\
\hline Description & 76\% thermal efficiency & Same as 2010 \\
\hline Increase in installed cost* $(\$)$ & $\$ 1783$ & $\$ 1533$ \\
\hline Annual energy savings* (MMBtu) & 55.9 & 55.9 \\
\hline CCE (\$/MMBtu) & $\$ 2.92$ & $\$ 2.51$ \\
\hline Decrease in LCC* $(\$)$ & $\$ 2272$ & $\$ 2931$ \\
\hline
\end{tabular}

* Relative to baseline technology.

Notes: This product accounts for about $4 \%$ of the furnaces and boiler market for commercial space heating and covers about $7 \%$ of the commercial floor space heating.

Source(s): U.S. Department of Energy (DOE)-Office of Energy Efficiency and Renewable Energy. 2000.

"Screening Analysis for EPACT-Covered Commercial HVAC and Water-Heating Equipment, Volume 1 - Main Report and Volume 2 - Appendix Material.” Washington, DC. April, 2000. Table 2.4, Table 3.8, Appendix D3-D80.

Sector: Commercial

End Use: Space Heating

Product: Packaged Boiler, Gas-Fired, Steam (1500 kBtu/hr)

Lifetime (years): 30

Baseline Technology: 72\% thermal efficiency

Baseline Installed Cost in 2010: \$15,476

Baseline Annual Energy Consumption: 1983 MMBtu

Baseline Life Cycle Cost in 2010: \$159,929

\begin{tabular}{|l|c|c|}
\hline & $\begin{array}{c}\text { Technology for 2010 } \\
\text { Standard }\end{array}$ & Technology for 2020 Standard \\
\hline Description & $79 \%$ thermal efficiency & Same as 2010 \\
\hline Increase in installed cost* $(\$)$ & $\$ 6302$ & $\$ 5418$ \\
\hline Annual energy savings* $(\mathrm{MMBtu})$ & 175.8 & 175.8 \\
\hline CCE $(\$$ MMBtu) & $\$ 3.27$ & $\$ 2.81$ \\
\hline Decrease in LCC* $(\$)$ & $\$ 6498$ & $\$ 8673$ \\
\hline
\end{tabular}

* Relative to baseline technology.

Notes: This product accounts for about $1 \%$ of the furnaces and boiler market for commercial space heating and covers about $1.6 \%$ of the commercial floor space heating.

Source(s): U.S. Department of Energy (DOE)-Office of Energy Efficiency and Renewable Energy. 2000.

"Screening Analysis for EPACT-Covered Commercial HVAC and Water-Heating Equipment, Volume 1 - Main Report and Volume 2 - Appendix Material.” Washington, DC. April, 2000. Table 2.4, Table 3.8, Appendix D3-D80. 
Sector: Commercial

End Use: Space Heating

Product: Packaged Boiler, Gas-Fired, Steam (3000 kBtu/hr)

Lifetime (years): 30

Baseline Technology: 72\% thermal efficiency

Baseline Installed Cost in 2010: \$22,173

Baseline Annual Energy Consumption: 3967 MMBtu

Baseline Life Cycle Cost in 2010: \$311,079

\begin{tabular}{|l|c|c|}
\hline & $\begin{array}{c}\text { Technology for 2010 } \\
\text { Standard }\end{array}$ & $\begin{array}{c}\text { Technology for 2020 } \\
\text { Standard }\end{array}$ \\
\hline Description & $80 \%$ thermal efficiency & Same as 2010 \\
\hline Increase in installed cost* $(\$)$ & $\$ 8425$ & $\$ 7244$ \\
\hline Annual energy savings* (MMBtu) & 396.8 & 396.8 \\
\hline CCE (\$/MMBtu) & $\$ 1.94$ & $\$ 1.66$ \\
\hline Decrease in LCC* $(\$)$ & $\$ 20,465$ & $\$ 24,562$ \\
\hline
\end{tabular}

* Relative to baseline technology.

Notes: This product accounts for about $0.3 \%$ of the furnaces and boiler market for commercial space heating and covers about $0.5 \%$ of the commercial floor space heating.

Source(s): U.S. Department of Energy (DOE)-Office of Energy Efficiency and Renewable Energy. 2000.

"Screening Analysis for EPACT-Covered Commercial HVAC and Water-Heating Equipment, Volume 1 - Main Report and Volume 2 - Appendix Material.” Washington, DC. April, 2000. Table 2.4, Table 3.8, Appendix D3-D80.

Sector: Commercial

End Use: Space Heating

Product: Warm-Air Furnace, Gas-Fired (250 kBtu/hr)

Lifetime (years): 15

Baseline Technology: 78\% thermal efficiency

Baseline Installed Cost in 2010: \$7,835

Baseline Annual Energy Consumption: 224 MMBtu

Baseline Life Cycle Cost in 2010: \$24,179

\begin{tabular}{|l|c|c|}
\hline & $\begin{array}{c}\text { Technology for 2010 } \\
\text { Standard }\end{array}$ & $\begin{array}{c}\text { Technology for 2020 } \\
\text { Standard }\end{array}$ \\
\hline Description & $80 \%$ thermal efficiency & Same as 2010 \\
\hline Increase in installed cost* $(\$)$ & $\$ 403$ & $\$ 347$ \\
\hline Annual energy savings* (MMBtu) & 5.6 & 5.6 \\
\hline CCE (\$/MMBtu) & $\$ 6.52$ & $\$ 5.60$ \\
\hline Decrease in LCC* $(\$)$ & $\$ 8$ & $\$ 106$ \\
\hline
\end{tabular}

* Relative to baseline technology.

Notes: This product accounts for about $46 \%$ of the furnaces and boiler market for commercial space heating and covers about $19 \%$ of the commercial floor space heating.

Source(s): U.S. Department of Energy (DOE)-Office of Energy Efficiency and Renewable Energy. 2000.

"Screening Analysis for EPACT-Covered Commercial HVAC and Water-Heating Equipment, Volume 1 - Main Report and Volume 2 - Appendix Material.” Washington, DC. April, 2000. Table 2.4, Table 3.8, Appendix D3-D80. 
Sector: Commercial

End Use: Space Heating

Product: Warm-Air Furnace, Gas-Fired (400 kBtu/hr)

Lifetime (years): 15

Baseline Technology: 78\% thermal efficiency

Baseline Installed Cost in 2010: \$11,712

Baseline Annual Energy Consumption: 359 MMBtu

Baseline Life Cycle Cost in 2010: \$37,863

\begin{tabular}{|l|c|c|}
\hline & $\begin{array}{c}\text { Technology for 2010 } \\
\text { Standard }\end{array}$ & $\begin{array}{c}\text { Technology for 2020 } \\
\text { Standard }\end{array}$ \\
\hline Description & $80 \%$ thermal efficiency & Same as 2010 \\
\hline Increase in installed cost* $(\$)$ & $\$ 510$ & $\$ 438$ \\
\hline Annual energy savings* $(\mathrm{MMBtu})$ & 9.0 & 9.0 \\
\hline CCE (\$/MMBtu) & $\$ 5.14$ & $\$ 4.42$ \\
\hline Decrease in LCC* $(\$)$ & $\$ 148$ & $\$ 286$ \\
\hline
\end{tabular}

* Relative to baseline technology.

Notes: This product accounts for about 30\% of the furnaces and boiler market for commercial space heating and covers about $12 \%$ of the commercial floor space heating.

Source(s): U.S. Department of Energy (DOE)-Office of Energy Efficiency and Renewable Energy. 2000.

"Screening Analysis for EPACT-Covered Commercial HVAC and Water-Heating Equipment, Volume 1 - Main Report and Volume 2 - Appendix Material.” Washington, DC. April, 2000. Table 2.4, Table 3.8, Appendix D3-D80.

Sector: Commercial

End Use: Air Conditioning

Product: 3-Phase, Single-Package, Air-Source AC ( $<65$ kBtu/h)

Lifetime (years): 15

Baseline Technology: 9.7 SEER

Baseline Installed Cost in 2010: \$2,618

Baseline Annual Energy Consumption: 10,036 kWh

Baseline Life Cycle Cost in 2010: \$11,062

\begin{tabular}{|l|c|c|}
\hline & Technology for 2010 Standard & Technology for 2020 Standard \\
\hline Description & 12 SEER & Same as 2010 \\
\hline Increase in installed cost* $(\$)$ & $\$ 785$ & $\$ 675$ \\
\hline Annual energy savings* $(\mathrm{kWh})$ & 1924 & 1924 \\
\hline CCE $(\mathbb{4} / \mathrm{kWh})$ & 4.2 & 3.6 \\
\hline Decrease in LCC* $(\$)$ & $\$ 833$ & $\$ 1008$ \\
\hline
\end{tabular}

* Relative to baseline technology.

Notes: This product accounts for about 7\% of the air-conditioning market for commercial space cooling and covers about $9 \%$ of the commercial floor space cooling.

Source(s): U.S. Department of Energy (DOE)-Office of Energy Efficiency and Renewable Energy. 2000.

"Screening Analysis for EPACT-Covered Commercial HVAC and Water-Heating Equipment, Volume 1 - Main Report and Volume 2 - Appendix Material.” Washington, DC. April, 2000. Table 2.5, Table 3.8, Appendix D3-D80. 
Sector: Commercial

End Use: Air Conditioning

Product: 3-Phase, Split-System, Air-Source AC ( $<65$ kBtu/h)

Lifetime (years): 15

Baseline Technology: 10 SEER

Baseline Installed Cost in 2010: \$2,666

Baseline Annual Energy Consumption: $9735 \mathrm{kWh}$

Baseline Life Cycle Cost in 2010: \$10,857

\begin{tabular}{|l|c|c|}
\hline & $\begin{array}{c}\text { Technology for 2010 } \\
\text { Standard }\end{array}$ & $\begin{array}{c}\text { Technology for 2020 } \\
\text { Standard }\end{array}$ \\
\hline Description & 12 SEER & Same as 2010 \\
\hline Increase in installed cost* $(\$)$ & $\$ 960$ & $\$ 826$ \\
\hline Annual energy savings* $(\mathrm{kWh})$ & 1623 & 1623 \\
\hline CCE $(\$ / \mathrm{kWh})$ & 6.0 & 5.2 \\
\hline Decrease in LCC* $(\$)$ & $\$ 405$ & $\$ 594$ \\
\hline
\end{tabular}

* Relative to baseline technology.

Notes: This product accounts for about $12 \%$ of the air-conditioning market for commercial space cooling and covers about $16 \%$ of the commercial floor space cooling.

Source(s): U.S. Department of Energy (DOE)-Office of Energy Efficiency and Renewable Energy. 2000.

"Screening Analysis for EPACT-Covered Commercial HVAC and Water-Heating Equipment, Volume 1 - Main Report and Volume 2 - Appendix Material.” Washington, DC. April, 2000. Table 2.5, Table 3.8, Appendix D3-D80.

Sector: Commercial

End Use: Air Conditioning

Product: 3-Phase, Single-Package, Air-Source Heat Pump ( $<65$ kBtu/h)

Lifetime (years): 15

Baseline Technology: 9.7 SEER

Baseline Installed Cost in 2010: \$3,092

Baseline Annual Energy Consumption: 10,036 kWh

Baseline Life Cycle Cost in 2010: \$11,536

\begin{tabular}{|l|c|c|}
\hline & $\begin{array}{c}\text { Technology for 2010 } \\
\text { Standard }\end{array}$ & $\begin{array}{c}\text { Technology for 2020 } \\
\text { Standard }\end{array}$ \\
\hline Description & 12 SEER & Same as 2010 \\
\hline Increase in installed cost* $(\$)$ & $\$ 865$ & $\$ 744$ \\
\hline Annual energy savings* $(\mathrm{kWh})$ & 1924 & 1924 \\
\hline CCE $(\$ / \mathrm{kWh})$ & 4.6 & 3.9 \\
\hline Decrease in LCC* $(\$)$ & $\$ 753$ & $\$ 940$ \\
\hline
\end{tabular}

* Relative to baseline technology.

Notes: This product accounts for about $1.3 \%$ of the air-conditioning market for commercial space cooling and covers about $2 \%$ of the commercial floor space cooling.

Source(s): U.S. Department of Energy (DOE)-Office of Energy Efficiency and Renewable Energy. 2000.

"Screening Analysis for EPACT-Covered Commercial HVAC and Water-Heating Equipment, Volume 1 - Main

Report and Volume 2 - Appendix Material.” Washington, DC. April, 2000. Table 2.5, Table 3.8, Appendix D3-D80. 
Sector: Commercial

End Use: Air Conditioning

Product: 3-Phase, Split-System, Air-Source Heat Pump ( $<65$ kBtu/h)

Lifetime (years): 15

Baseline Technology: 10 SEER

Baseline Installed Cost in 2010: \$2,612

Baseline Annual Energy Consumption: 9,735 kWh

Baseline Life Cycle Cost in 2010: \$10,803

\begin{tabular}{|l|c|c|}
\hline & $\begin{array}{c}\text { Technology for 2010 } \\
\text { Standard }\end{array}$ & $\begin{array}{c}\text { Technology for 2020 } \\
\text { Standard }\end{array}$ \\
\hline Description & 13 SEER & Same as 2010 \\
\hline Increase in installed cost* $(\$)$ & $\$ 1149$ & $\$ 988$ \\
\hline Annual energy savings* $(\mathrm{kWh})$ & 2247 & 2247 \\
\hline CCE $(\$ / \mathrm{kWh})$ & 5.2 & 4.5 \\
\hline Decrease in LCC* $(\$)$ & $\$ 741$ & $\$ 978$ \\
\hline
\end{tabular}

* Relative to baseline technology.

Notes: This product accounts for about $6 \%$ of the air-conditioning market for commercial space cooling and covers about $7.5 \%$ of the commercial floor space cooling.

Source(s): U.S. Department of Energy (DOE)-Office of Energy Efficiency and Renewable Energy. 2000.

"Screening Analysis for EPACT-Covered Commercial HVAC and Water-Heating Equipment, Volume 1 - Main

Report and Volume 2 - Appendix Material.” Washington, DC. April, 2000. Table 2.5, Table 3.8, Appendix D3-D80.

Sector: Commercial

End Use: Air Conditioning

Product: Central, Air-Source AC ( $>65$ and $<135 \mathrm{kBtu} / \mathrm{h})$

Lifetime (years): 15

Baseline Technology: 10.1 EER

Baseline Installed Cost in 2010: \$6,732

Baseline Annual Energy Consumption: 16,079 kWh

Baseline Life Cycle Cost in 2010: \$19,677

\begin{tabular}{|l|c|c|}
\hline & $\begin{array}{c}\text { Technology for 2010 } \\
\text { Standard }\end{array}$ & $\begin{array}{c}\text { Technology for 2020 } \\
\text { Standard }\end{array}$ \\
\hline Description & 11.5 EER & 12.0 EER \\
\hline Increase in installed cost* $(\$)$ & $\$ 555$ & $\$ 982$ \\
\hline Annual energy savings* $(\mathrm{kWh})$ & 1769 & 2251 \\
\hline CCE $(\mathrm{\Phi} / \mathrm{kWh})$ & 3.2 & 4.5 \\
\hline Decrease in LCC* $(\$)$ & $\$ 887$ & $\$ 1001$ \\
\hline
\end{tabular}

* Relative to baseline technology.

Notes: This product accounts for about $11 \%$ of the air-conditioning market for commercial space cooling and covers about $15 \%$ of the commercial floor space cooling.

Source(s): U.S. Department of Energy (DOE)-Office of Energy Efficiency and Renewable Energy. 2004. "Commercial Unitary Air Conditioners and Heat Pumps, Energy Conservation Standards Rulemaking, Life Cycle Cost Analysis Spreadsheet Model (Tariff-Based Electricity Prices).” Washington, DC. Product Class: 7.5 tons. $<$ http://www.eere.energy.gov/buildings/appliance_standards/commercial/ac_hp.html> 
Sector: Commercial

End Use: Air Conditioning

Product: Central, Air-Source Heat Pump ( $>65$ and $<135$ kBtu/h)

Lifetime (years): 15

Baseline Technology: 10.1 EER

Baseline Installed Cost in 2010: \$6,732

Baseline Annual Energy Consumption: 16,079 kWh

Baseline Life Cycle Cost in 2010: \$19,677

\begin{tabular}{|l|c|c|}
\hline & $\begin{array}{c}\text { Technology for 2010 } \\
\text { Standard }\end{array}$ & $\begin{array}{c}\text { Technology for 2020 } \\
\text { Standard }\end{array}$ \\
\hline Description & 11.5 EER & 12.0 EER \\
\hline Increase in installed cost* $(\$)$ & $\$ 555$ & $\$ 982$ \\
\hline Annual energy savings* $(\mathrm{kWh})$ & 1769 & 2251 \\
\hline CCE $(\$ / \mathrm{kWh})$ & 3.2 & 4.5 \\
\hline Decrease in LCC* $(\$)$ & $\$ 887$ & $\$ 1001$ \\
\hline
\end{tabular}

* Relative to baseline technology.

Notes: This product accounts for about $1 \%$ of the air-conditioning market for commercial space cooling and covers about $1 \%$ of the commercial floor space cooling.

Source(s): U.S. Department of Energy (DOE)-Office of Energy Efficiency and Renewable Energy. 2004.

"Commercial Unitary Air Conditioners and Heat Pumps, Energy Conservation Standards Rulemaking, Life Cycle Cost Analysis Spreadsheet Model (Tariff-Based Electricity Prices).” Washington, DC. Product Class: 7.5 tons.

$<$ http://www.eere.energy.gov/buildings/appliance_standards/commercial/ac_hp.html>

Sector: Commercial

End Use: Air Conditioning

Product: Central, Water-Source Heat Pump ( $>65$ and $<135$ kBtu/h)

Lifetime (years): 19

Baseline Technology: 12 EER

Baseline Installed Cost in 2010: \$3,984

Baseline Annual Energy Consumption: 11,528 kWh

Baseline Life Cycle Cost in 2010: \$13,684

\begin{tabular}{|l|c|c|}
\hline & $\begin{array}{c}\text { Technology for 2010 } \\
\text { Standard }\end{array}$ & $\begin{array}{c}\text { Technology for 2020 } \\
\text { Standard }\end{array}$ \\
\hline Description & 12.5 EER & 13.0 EER \\
\hline Increase in installed cost* $(\$)$ & $\$ 324$ & $\$ 644$ \\
\hline Annual energy savings* $(\mathrm{kWh})$ & 461 & 887 \\
\hline CCE $($ \&/kWh) & 7.2 & 7.4 \\
\hline Decrease in LCC* $(\$)$ & $\$ 64$ & $\$ 132$ \\
\hline
\end{tabular}

* Relative to baseline technology.

Notes: This product accounts for about $9 \%$ of the air-conditioning market for commercial space cooling and covers about $11 \%$ of the commercial floor space cooling.

Source(s): U.S. Department of Energy (DOE)-Office of Energy Efficiency and Renewable Energy. 2000.

"Screening Analysis for EPACT-Covered Commercial HVAC and Water-Heating Equipment, Volume 1 - Main

Report and Volume 2 - Appendix Material.” Washington, DC. April, 2000. Table 2.5, Table 3.8, Appendix D3-D80. 
Sector: Commercial

End Use: Air Conditioning

Product: Central, Water-Cooled AC ( $>65$ and $<135 \mathrm{kBtu} / \mathrm{h})$

Lifetime (years): 19

Baseline Technology: 11.5 EER

Baseline Installed Cost in 2010: \$4,118

Baseline Annual Energy Consumption: 12,029 kWh

Baseline Life Cycle Cost in 2010: \$14,240

\begin{tabular}{|l|c|c|}
\hline & $\begin{array}{c}\text { Technology for 2010 } \\
\text { Standard }\end{array}$ & $\begin{array}{c}\text { Technology for 2020 } \\
\text { Standard }\end{array}$ \\
\hline Description & 12.4 EER & 14.0 EER \\
\hline Increase in installed cost* $(\$)$ & $\$ 508$ & $\$ 1445$ \\
\hline Annual energy savings* $(\mathrm{kWh})$ & 873 & 2148 \\
\hline CCE $(\$ / \mathrm{kWh})$ & 5.9 & 6.9 \\
\hline Decrease in LCC* $(\$)$ & $\$ 227$ & $\$ 435$ \\
\hline
\end{tabular}

* Relative to baseline technology.

Notes: This product accounts for less than $1 \%$ of the air-conditioning market for commercial space cooling and covers less than $1 \%$ of the commercial cooled floor space.

Source(s): U.S. Department of Energy (DOE)-Office of Energy Efficiency and Renewable Energy. 2000.

"Screening Analysis for EPACT-Covered Commercial HVAC and Water-Heating Equipment, Volume 1 - Main

Report and Volume 2 - Appendix Material.” Washington, DC. April, 2000. Table 2.5, Table 3.8, Appendix D3-D80.

Sector: Commercial

End Use: Air Conditioning

Product: Central, Air-Source AC ( $>135$ and $<240 \mathrm{kBtu} / \mathrm{h})$

Lifetime (years): 15

Baseline Technology: 9.5 EER

Baseline Installed Cost in 2010: \$11,812

Baseline Annual Energy Consumption: 33,953 kWh

Baseline Life Cycle Cost in 2010: \$39,356

\begin{tabular}{|l|c|c|}
\hline & $\begin{array}{c}\text { Technology for 2010 } \\
\text { Standard }\end{array}$ & $\begin{array}{c}\text { Technology for 2020 } \\
\text { Standard }\end{array}$ \\
\hline Description & 11.5 EER & 12.0 EER \\
\hline Increase in installed cost* $(\$)$ & $\$ 1357$ & $\$ 2173$ \\
\hline Annual energy savings* $(\mathrm{kWh})$ & 5220 & 6239 \\
\hline CCE $(\$ / \mathrm{kWh})$ & 2.7 & 3.6 \\
\hline Decrease in LCC* $(\$)$ & $\$ 2879$ & $\$ 3213$ \\
\hline
\end{tabular}

* Relative to baseline technology.

Notes: This product accounts for about $8 \%$ of the air-conditioning market for commercial space cooling and covers about $11 \%$ of the commercial floor space cooling.

Source(s): U.S. Department of Energy (DOE)-Office of Energy Efficiency and Renewable Energy. 2004. "Commercial Unitary Air Conditioners and Heat Pumps, Energy Conservation Standards Rulemaking, Life Cycle Cost Analysis Spreadsheet Model (Tariff-Based Electricity Prices).” Washington, DC. Product Class: 7.5 tons. $<$ http://www.eere.energy.gov/buildings/appliance_standards/commercial/ac_hp.html> 
Sector: Commercial

End Use: Air Conditioning

Product: Central, Air-Source Heat Pump ( $>135$ and $<240$ kBtu/h)

Lifetime (years): 15

Baseline Technology: 9.5 EER

Baseline Installed Cost in 2010: \$11,812

Baseline Annual Energy Consumption: 33,953 kWh

Baseline Life Cycle Cost in 2010: \$39,356

\begin{tabular}{|l|c|c|}
\hline & $\begin{array}{c}\text { Technology for 2010 } \\
\text { Standard }\end{array}$ & $\begin{array}{c}\text { Technology for 2020 } \\
\text { Standard }\end{array}$ \\
\hline Description & 11.5 EER & 12.0 EER \\
\hline Increase in installed cost* $(\$)$ & $\$ 1357$ & $\$ 2173$ \\
\hline Annual energy savings* $(\mathrm{kWh})$ & 5220 & 6239 \\
\hline CCE $(\mathrm{\Phi} / \mathrm{kWh})$ & 2.7 & 3.6 \\
\hline Decrease in LCC* $(\$)$ & $\$ 2879$ & $\$ 3213$ \\
\hline
\end{tabular}

* Relative to baseline technology.

Notes: This product accounts for less than $1 \%$ of the air-conditioning market for commercial space cooling and covers less than $1 \%$ of the commercial floor space cooling.

Source(s): U.S. Department of Energy (DOE)-Office of Energy Efficiency and Renewable Energy. 2004.

"Commercial Unitary Air Conditioners and Heat Pumps, Energy Conservation Standards Rulemaking, Life Cycle Cost Analysis Spreadsheet Model (Tariff-Based Electricity Prices).” Washington, DC. Product Class: 7.5 tons.

$<$ http://www.eere.energy.gov/buildings/appliance_standards/commercial/ac_hp.html>

Sector: Commercial

End Use: Air Conditioning

Product: Central, Water-Cooled AC ( $>135$ and $<240 \mathrm{kBtu} / \mathrm{h})$

Lifetime (years): 19

Baseline Technology: 11 EER

Baseline Installed Cost in 2010: \$9,632

Baseline Annual Energy Consumption: 25,152 kWh

Baseline Life Cycle Cost in 2010: \$30,795

\begin{tabular}{|l|c|c|}
\hline & $\begin{array}{c}\text { Technology for 2010 } \\
\text { Standard }\end{array}$ & $\begin{array}{c}\text { Technology for 2020 } \\
\text { Standard }\end{array}$ \\
\hline Description & 11.5 EER & Same as 2010 \\
\hline Increase in installed cost* $(\$)$ & $\$ 309$ & $\$ 266$ \\
\hline Annual energy savings* $(\mathrm{kWh})$ & 1094 & 1094 \\
\hline CCE $(\mathbb{\mathrm { k }} / \mathrm{kWh})$ & 2.9 & 2.5 \\
\hline Decrease in LCC* $(\$)$ & $\$ 611$ & $\$ 691$ \\
\hline
\end{tabular}

* Relative to baseline technology.

Notes: This product accounts for less than $1 \%$ of the air-conditioning market for commercial space cooling and covers less than $1 \%$ of the commercial floor space cooling.

Source(s): U.S. Department of Energy (DOE)-Office of Energy Efficiency and Renewable Energy. 2000.

"Screening Analysis for EPACT-Covered Commercial HVAC and Water-Heating Equipment, Volume 1 - Main

Report and Volume 2 - Appendix Material.” Washington, DC. April, 2000. Table 2.5, Table 3.8, Appendix D3-D80. 
Sector: Commercial

End Use: Air Conditioning

Product: Central, Water-Cooled AC $(<65 \mathrm{kBtu} / \mathrm{h})$

Lifetime (years): 19

Baseline Technology: 12.1 EER

Baseline Installed Cost in 2010: \$4,396

Baseline Annual Energy Consumption: 8,045 kWh

Baseline Life Cycle Cost in 2010: \$11,165

\begin{tabular}{|l|c|c|}
\hline & $\begin{array}{c}\text { Technology for 2010 } \\
\text { Standard }\end{array}$ & $\begin{array}{c}\text { Technology for 2020 } \\
\text { Standard }\end{array}$ \\
\hline Description & 12.1 EER & 12.5 EER \\
\hline Increase in installed cost* $(\$)$ & N/A & $\$ 190$ \\
\hline Annual energy savings* $(\mathrm{kWh})$ & N/A & 257 \\
\hline CCE $(\mathbb{\$} / \mathrm{kWh})$ & N/A & 7.5 \\
\hline Decrease in LCC* $(\$)$ & N/A & $\$ 36$ \\
\hline
\end{tabular}

* Relative to baseline technology.

Notes: This product accounts for less than $1 \%$ of the air-conditioning market for commercial space cooling and covers less than $1 \%$ of the commercial floor space cooling.

Source(s): U.S. Department of Energy (DOE)-Office of Energy Efficiency and Renewable Energy. 2000.

"Screening Analysis for EPACT-Covered Commercial HVAC and Water-Heating Equipment, Volume 1 - Main

Report and Volume 2 - Appendix Material.” Washington, DC. April, 2000. Table 2.5, Table 3.8, Appendix D3-D80.

Sector: Commercial

End Use: Air Conditioning

Product: Central, Water-Source Heat Pump ( $<17$ kBtu/h)

Lifetime (years): 19

Baseline Technology: 11.2 EER

Baseline Installed Cost in 2010: \$876

Baseline Annual Energy Consumption: 1,738 kWh

Baseline Life Cycle Cost in 2010: \$2,338

\begin{tabular}{|l|c|c|}
\hline & $\begin{array}{c}\text { Technology for 2010 } \\
\text { Standard }\end{array}$ & $\begin{array}{c}\text { Technology for 2020 } \\
\text { Standard }\end{array}$ \\
\hline Description & 11.2 EER & 12.5 EER \\
\hline Increase in installed cost* $(\$)$ & N/A & \$139 \\
\hline Annual energy savings* $(\mathrm{kWh})$ & N/A & 181 \\
\hline CCE $(\$ / k W h)$ & N/A & 7.8 \\
\hline Decrease in LCC* $(\$)$ & N/A & $\$ 19$ \\
\hline
\end{tabular}

* Relative to baseline technology.

Notes: This product accounts for about $1 \%$ of the air-conditioning market for commercial space cooling and covers about $1 \%$ of the commercial cooled floor space.

Source(s): U.S. Department of Energy (DOE)-Office of Energy Efficiency and Renewable Energy. 2000.

"Screening Analysis for EPACT-Covered Commercial HVAC and Water-Heating Equipment, Volume 1 - Main

Report and Volume 2 - Appendix Material.” Washington, DC. April, 2000. Table 2.5, Table 3.8, Appendix D3-D80. 
Sector: Commercial

End Use: Air Conditioning

Product: Central, Water-Source Heat Pump ( $>17$ and $<65$ kBtu/h)

Lifetime (years): 19

Baseline Technology: 12 EER

Baseline Installed Cost in 2010: \$1,346

Baseline Annual Energy Consumption: 4,867 kWh

Baseline Life Cycle Cost in 2010: \$5,442

\begin{tabular}{|l|c|c|}
\hline & $\begin{array}{c}\text { Technology for 2010 } \\
\text { Standard }\end{array}$ & $\begin{array}{c}\text { Technology for 2020 } \\
\text { Standard }\end{array}$ \\
\hline Description & 13.1 EER & Same as 2010 \\
\hline Increase in installed cost* $(\$)$ & $\$ 286$ & $\$ 246$ \\
\hline Annual energy savings* $(\mathrm{kWh})$ & 409 & 409 \\
\hline CCE $(\mathrm{\$} / \mathrm{kWh})$ & 7.1 & 6.1 \\
\hline Decrease in LCC* $(\$)$ & $\$ 58$ & $\$ 112$ \\
\hline
\end{tabular}

* Relative to baseline technology.

Notes: This product accounts for about $1 \%$ of the air-conditioning market for commercial space cooling and covers about $1 \%$ of the commercial floor space cooling.

Source(s): U.S. Department of Energy (DOE)-Office of Energy Efficiency and Renewable Energy. 2000.

"Screening Analysis for EPACT-Covered Commercial HVAC and Water-Heating Equipment, Volume 1 - Main

Report and Volume 2 - Appendix Material.” Washington, DC. April, 2000. Table 2.5, Table 3.8, Appendix D3-D80.

Sector: Commercial

End Use: Air Conditioning

Product: Packaged Terminal Air Conditioner (PTAC) $(<7 \mathrm{kBtu} / \mathrm{h})$

Lifetime (years): 15

Baseline Technology: 9.4 EER

Baseline Installed Cost in 2010: \$734

Baseline Annual Energy Consumption: $1331 \mathrm{kWh}$

Baseline Life Cycle Cost in 2010: \$1,854

\begin{tabular}{|l|c|c|}
\hline & $\begin{array}{c}\text { Technology for 2010 } \\
\text { Standard }\end{array}$ & $\begin{array}{c}\text { Technology for 2020 } \\
\text { Standard }\end{array}$ \\
\hline Description & 11 EER & Same as 2010 \\
\hline Increase in installed cost* $(\$)$ & $\$ 110$ & $\$ 95$ \\
\hline Annual energy savings* $(\mathrm{kWh})$ & 194 & 194 \\
\hline CCE $(\$ / \mathrm{kWh})$ & 5.8 & 5.0 \\
\hline Decrease in LCC* $(\$)$ & $\$ 53$ & $\$ 75$ \\
\hline
\end{tabular}

* Relative to baseline technology.

Notes: This product accounts for about $4 \%$ of the packaged terminal air-conditioning market and covers less than $1 \%$ of the commercial floor space cooling.

Source(s): U.S. Department of Energy (DOE)-Office of Energy Efficiency and Renewable Energy. 2000.

"Screening Analysis for EPACT-Covered Commercial HVAC and Water-Heating Equipment, Volume 1 - Main Report and Volume 2 - Appendix Material.” Washington, DC. April, 2000. Table 2.5, Table 3.8, Appendix D3-D80. 
Sector: Commercial

End Use: Air Conditioning

Product: Packaged Terminal Air Conditioner (PTAC) (7-10 kBtu/h)

Lifetime (years): 15

Baseline Technology: 9 EER

Baseline Installed Cost in 2010: \$807

Baseline Annual Energy Consumption: 1688 kWh

Baseline Life Cycle Cost in 2010: \$2,227

\begin{tabular}{|l|c|c|}
\hline & $\begin{array}{c}\text { Technology for 2010 } \\
\text { Standard }\end{array}$ & $\begin{array}{c}\text { Technology for 2020 } \\
\text { Standard }\end{array}$ \\
\hline Description & 10.8 EER & Same as 2010 \\
\hline Increase in installed cost* $(\$)$ & $\$ 105$ & $\$ 91$ \\
\hline Annual energy savings* $(\mathrm{kWh})$ & 281 & 281 \\
\hline CCE $(\mathrm{f} / \mathrm{kWh})$ & 3.8 & 3.3 \\
\hline Decrease in LCC* $(\$)$ & $\$ 131$ & $\$ 156$ \\
\hline
\end{tabular}

* Relative to baseline technology.

Notes: This product accounts for about $20 \%$ of the packaged terminal air-conditioning market and covers $1.4 \%$ of the commercial floor space cooling.

Source(s): U.S. Department of Energy (DOE)-Office of Energy Efficiency and Renewable Energy. 2000. "Screening Analysis for EPACT-Covered Commercial HVAC and Water-Heating Equipment, Volume 1 - Main Report and Volume 2 - Appendix Material.” Washington, DC. April, 2000. Table 2.5, Table 3.8, Appendix D3-D80.

Sector: Commercial

End Use: Air Conditioning

Product: Packaged Terminal Air Conditioner (PTAC) (10-13 kBtu/h)

Lifetime (years): 15

Baseline Technology: 8.3 EER

Baseline Installed Cost in 2010: \$716

Baseline Annual Energy Consumption: 2476 kWh

Baseline Life Cycle Cost in 2010: \$2,800

\begin{tabular}{|l|c|c|}
\hline & $\begin{array}{c}\text { Technology for 2010 } \\
\text { Standard }\end{array}$ & $\begin{array}{c}\text { Technology for 2020 } \\
\text { Standard }\end{array}$ \\
\hline Description & 10.5 EER & Same as 2010 \\
\hline Increase in installed cost* $(\$)$ & $\$ 211$ & $\$ 181$ \\
\hline Annual energy savings* $(\mathrm{kWh})$ & 519 & 519 \\
\hline CCE $(\$ / \mathrm{kWh})$ & 4.1 & 3.6 \\
\hline Decrease in LCC* $(\$)$ & $\$ 226$ & $\$ 273$ \\
\hline
\end{tabular}

* Relative to baseline technology.

Notes: This product accounts for about 21\% of the packaged terminal air-conditioning market and covers $1.5 \%$ of the commercial floor space cooling.

Source(s): U.S. Department of Energy (DOE)-Office of Energy Efficiency and Renewable Energy. 2000. "Screening Analysis for EPACT-Covered Commercial HVAC and Water-Heating Equipment, Volume 1 - Main Report and Volume 2 - Appendix Material.” Washington, DC. April, 2000. Table 2.5, Table 3.8, Appendix D3-D80. 
Sector: Commercial

End Use: Air Conditioning

Product: Packaged Terminal Air Conditioner (PTAC) (>13 kBtu/h)

Lifetime (years): 15

Baseline Technology: 7.9 EER

Baseline Installed Cost in 2010: \$887

Baseline Annual Energy Consumption: 3168 kWh

Baseline Life Cycle Cost in 2010: \$3,552

\begin{tabular}{|l|c|c|}
\hline & $\begin{array}{c}\text { Technology for 2010 } \\
\text { Standard }\end{array}$ & $\begin{array}{c}\text { Technology for 2020 } \\
\text { Standard }\end{array}$ \\
\hline Description & 10 EER & Same as 2010 \\
\hline Increase in installed cost* $(\$)$ & $\$ 126$ & $\$ 108$ \\
\hline Annual energy savings* $(\mathrm{kWh})$ & 665 & 665 \\
\hline CCE $(\$ / \mathrm{kWh})$ & 1.9 & 1.7 \\
\hline Decrease in LCC* $(\$)$ & $\$ 434$ & $\$ 474$ \\
\hline
\end{tabular}

* Relative to baseline technology.

Notes: This product accounts for about $9 \%$ of the packaged terminal air-conditioning market and covers $0.7 \%$ of the commercial floor space cooling.

Source(s): U.S. Department of Energy (DOE)-Office of Energy Efficiency and Renewable Energy. 2000.

"Screening Analysis for EPACT-Covered Commercial HVAC and Water-Heating Equipment, Volume 1 - Main

Report and Volume 2 - Appendix Material.” Washington, DC. April, 2000. Table 2.5, Table 3.8, Appendix D3-D80.

Sector: Commercial

End Use: Air Conditioning

Product: Packaged Terminal Heat Pump (PTHP) $(<7$ kBtu/h)

Lifetime (years): 15

Baseline Technology: 9.3 EER

Baseline Installed Cost in 2010: \$810

Baseline Annual Energy Consumption: 1345 kWh

Baseline Life Cycle Cost in 2010: \$1,942

\begin{tabular}{|l|c|c|}
\hline & $\begin{array}{c}\text { Technology for 2010 } \\
\text { Standard }\end{array}$ & $\begin{array}{c}\text { Technology for 2020 } \\
\text { Standard }\end{array}$ \\
\hline Description & 10.8 EER & Same as 2010 \\
\hline Increase in installed cost* $(\$)$ & $\$ 107$ & $\$ 92$ \\
\hline Annual energy savings* $(\mathrm{kWh})$ & 187 & 187 \\
\hline CCE $(\$ / \mathrm{kWh})$ & 5.8 & 5.0 \\
\hline Decrease in LCC* $(\$)$ & $\$ 50$ & $\$ 71$ \\
\hline
\end{tabular}

* Relative to baseline technology.

Notes: This product accounts for about $3 \%$ of the packaged terminal air-conditioning market and covers $0.2 \%$ of the commercial floor space cooling.

Source(s): U.S. Department of Energy (DOE)-Office of Energy Efficiency and Renewable Energy. 2000.

"Screening Analysis for EPACT-Covered Commercial HVAC and Water-Heating Equipment, Volume 1 - Main

Report and Volume 2 - Appendix Material.” Washington, DC. April, 2000. Table 2.5, Table 3.8, Appendix D3-D80. 
Sector: Commercial

End Use: Air Conditioning

Product: Packaged Terminal Heat Pump (PTHP) (7-10 kBtu/h)

Lifetime (years): 15

Baseline Technology: 8.9 EER

Baseline Installed Cost in 2010: \$895

Baseline Annual Energy Consumption: 1707 kWh

Baseline Life Cycle Cost in 2010: \$2,331

\begin{tabular}{|l|c|c|}
\hline & $\begin{array}{c}\text { Technology for 2010 } \\
\text { Standard }\end{array}$ & $\begin{array}{c}\text { Technology for 2020 } \\
\text { Standard }\end{array}$ \\
\hline Description & 10.6 EER & 11.4 EER \\
\hline Increase in installed cost* $(\$)$ & $\$ 93$ & $\$ 164$ \\
\hline Annual energy savings* $(\mathrm{kWh})$ & 274 & 374 \\
\hline CCE $(\$ / \mathrm{kWh})$ & 3.4 & 4.5 \\
\hline Decrease in LCC* $(\$)$ & $\$ 138$ & $\$ 164$ \\
\hline
\end{tabular}

* Relative to baseline technology.

Notes: This product accounts for about 19\% of the packaged terminal air-conditioning market and covers $1.4 \%$ of the commercial floor space cooling.

Source(s): U.S. Department of Energy (DOE)-Office of Energy Efficiency and Renewable Energy. 2000. "Screening Analysis for EPACT-Covered Commercial HVAC and Water-Heating Equipment, Volume 1 - Main Report and Volume 2 - Appendix Material.” Washington, DC. April, 2000. Table 2.5, Table 3.8, Appendix D3-D80.

Sector: Commercial

End Use: Air Conditioning

Product: Packaged Terminal Heat Pump (PTHP) (10-13 kBtu/h)

Lifetime (years): 15

Baseline Technology: 8.2 EER

Baseline Installed Cost in 2010: \$777

Baseline Annual Energy Consumption: $2507 \mathrm{kWh}$

Baseline Life Cycle Cost in 2010: \$2,887

\begin{tabular}{|l|c|c|}
\hline & $\begin{array}{c}\text { Technology for 2010 } \\
\text { Standard }\end{array}$ & $\begin{array}{c}\text { Technology for 2020 } \\
\text { Standard }\end{array}$ \\
\hline Description & 9.7 EER & Same as 2010 \\
\hline Increase in installed cost* $(\$)$ & $\$ 108$ & $\$ 93$ \\
\hline Annual energy savings* $(\mathrm{kWh})$ & 388 & 388 \\
\hline CCE $(\$ / \mathrm{kWh})$ & 2.8 & 2.4 \\
\hline Decrease in LCC* $(\$)$ & $\$ 218$ & $\$ 246$ \\
\hline
\end{tabular}

* Relative to baseline technology.

Notes: This product accounts for about $16 \%$ of the packaged terminal air-conditioning market and covers $1.1 \%$ of the commercial floor space cooling.

Source(s): U.S. Department of Energy (DOE)-Office of Energy Efficiency and Renewable Energy. 2000. "Screening Analysis for EPACT-Covered Commercial HVAC and Water-Heating Equipment, Volume 1 - Main Report and Volume 2 - Appendix Material.” Washington, DC. April, 2000. Table 2.5, Table 3.8, Appendix D3-D80. 
Sector: Commercial

End Use: Air Conditioning

Product: Packaged Terminal Heat Pump (PTHP) ( $>13$ kBtu/h)

Lifetime (years): 15

Baseline Technology: 7.8 EER

Baseline Installed Cost in 2010: \$944

Baseline Annual Energy Consumption: 3208 kWh

Baseline Life Cycle Cost in 2010: \$3,643

\begin{tabular}{|l|c|c|}
\hline & $\begin{array}{c}\text { Technology for 2010 } \\
\text { Standard }\end{array}$ & $\begin{array}{c}\text { Technology for 2020 } \\
\text { Standard }\end{array}$ \\
\hline Description & 10 EER & Same as 2010 \\
\hline Increase in installed cost* $(\$)$ & $\$ 326$ & $\$ 280$ \\
\hline Annual energy savings* $(\mathrm{kWh})$ & 706 & 706 \\
\hline CCE $(\$ / \mathrm{kWh})$ & 4.7 & 4.0 \\
\hline Decrease in LCC* $(\$)$ & $\$ 268$ & $\$ 338$ \\
\hline
\end{tabular}

* Relative to baseline technology.

Notes: This product accounts for about $8 \%$ of the packaged terminal air-conditioning market and covers $0.6 \%$ of the commercial floor space cooling.

Source(s): U.S. Department of Energy (DOE)-Office of Energy Efficiency and Renewable Energy. 2000.

"Screening Analysis for EPACT-Covered Commercial HVAC and Water-Heating Equipment, Volume 1 - Main

Report and Volume 2 - Appendix Material.” Washington, DC. April, 2000. Table 2.5, Table 3.8, Appendix D3-D80.

Sector: Commercial

End Use: Ventilation

Product: Air Distribution, Large Unitary (10 HP)

Lifetime (years): 15

Baseline Technology: 85\% efficiency

Baseline Installed Cost in 2010: not available

Baseline Annual Energy Consumption: not available

Baseline Life Cycle Cost in 2010: not available

\begin{tabular}{|l|c|c|}
\hline & $\begin{array}{c}\text { Technology for 2010 } \\
\text { Standard }\end{array}$ & $\begin{array}{c}\text { Technology for 2020 } \\
\text { Standard }\end{array}$ \\
\hline Description & $92 \%$ & Same as 2010 \\
\hline Increase in installed cost* $(\$)$ & $\$ 84$ & $\$ 72$ \\
\hline Annual energy savings* $(\mathrm{kWh})$ & 1795 & 1795 \\
\hline CCE $(\mathbf{\$} / \mathrm{kWh})$ & 0.5 & 0.4 \\
\hline Decrease in LCC* $(\$)$ & $\$ 1042$ & $\$ 1081$ \\
\hline
\end{tabular}

* Relative to baseline technology.

Notes: This product accounts for about 4\% of the energy consumption by Air Distribution units.

Source(s): Arthur D. Little. 1999. "Opportunities for Energy Savings in the Residential and Commercial Sectors with High Efficiency Electric Motors.” Cambridge, MA. December, 1999. Tables 4-3 and 4-4. 
Sector: Commercial

End Use: Ventilation

Product: Air Distribution, Exhaust Fan (0.5 HP)

Lifetime (years): 15

Baseline Technology: 60\% efficiency

Baseline Installed Cost in 2010: not available

Baseline Annual Energy Consumption: not available

Baseline Life Cycle Cost in 2010: not available

\begin{tabular}{|l|c|c|}
\hline & $\begin{array}{c}\text { Technology for 2010 } \\
\text { Standard }\end{array}$ & $\begin{array}{c}\text { Technology for 2020 } \\
\text { Standard }\end{array}$ \\
\hline Description & $80 \%$ & Same as 2010 \\
\hline Increase in installed cost* $(\$)$ & $\$ 13$ & $\$ 12$ \\
\hline Annual energy savings* $(\mathrm{kWh})$ & 710 & 710 \\
\hline CCE $(\$ / \mathrm{kWh})$ & 0.2 & 0.2 \\
\hline Decrease in LCC* $(\$)$ & $\$ 432$ & $\$ 444$ \\
\hline
\end{tabular}

* Relative to baseline technology.

Notes: This product accounts for about 38\% of the energy consumption by Air Distribution units

Source(s): Arthur D. Little. 1999. "Opportunities for Energy Savings in the Residential and Commercial Sectors with High Efficiency Electric Motors.” Cambridge, MA. December, 1999. Tables 4-3 and 4-4.

Sector: Commercial

End Use: Ventilation

Product: Air Distribution, Room Fan Coil (0.17 HP)

Lifetime (years): 15

Baseline Technology: 50\% efficiency

Baseline Installed Cost in 2010: not available

Baseline Annual Energy Consumption: not available

Baseline Life Cycle Cost in 2010: not available

\begin{tabular}{|l|c|c|}
\hline & $\begin{array}{c}\text { Technology for 2010 } \\
\text { Standard }\end{array}$ & $\begin{array}{c}\text { Technology for 2020 } \\
\text { Standard }\end{array}$ \\
\hline Description & $75 \%$ & Same as 2010 \\
\hline Increase in installed cost* $(\$)$ & $\$ 12$ & $\$ 10$ \\
\hline Annual energy savings* $(\mathrm{kWh})$ & 142 & 142 \\
\hline CCE $(\$ / \mathrm{kWh})$ & 0.9 & 0.7 \\
\hline Decrease in LCC* $(\$)$ & $\$ 77$ & $\$ 81$ \\
\hline
\end{tabular}

* Relative to baseline technology.

Notes: This product accounts for about 2\% of the energy consumption by Air Distribution units.

Source(s): Arthur D. Little. 1999. "Opportunities for Energy Savings in the Residential and Commercial Sectors with High Efficiency Electric Motors.” Cambridge, MA. December, 1999. Tables 4-3 and 4-4. 
Sector: Commercial

End Use: Ventilation

Product: Air Distribution, Central Station Air Handling Unit (10 HP)

Lifetime (years): 15

Baseline Technology: 87\% efficiency

Baseline Installed Cost in 2010: not available

Baseline Annual Energy Consumption: not available

Baseline Life Cycle Cost in 2010: not available

\begin{tabular}{|l|c|c|}
\hline & $\begin{array}{c}\text { Technology for 2010 } \\
\text { Standard }\end{array}$ & $\begin{array}{c}\text { Technology for 2020 } \\
\text { Standard }\end{array}$ \\
\hline Description & $93 \%$ & Same as 2010 \\
\hline Increase in installed cost* $(\$)$ & $\$ 84$ & $\$ 72$ \\
\hline Annual energy savings* $(\mathrm{kWh})$ & 1516 & 1516 \\
\hline CCE $(\$ / \mathrm{kWh})$ & 0.6 & 0.5 \\
\hline Decrease in LCC* $(\$)$ & $\$ 868$ & $\$ 902$ \\
\hline
\end{tabular}

* Relative to baseline technology.

Notes: This product accounts for about $40 \%$ of the energy consumption by Air Distribution units.

Source(s): Arthur D. Little. 1999. "Opportunities for Energy Savings in the Residential and Commercial Sectors with High Efficiency Electric Motors.” Cambridge, MA. December, 1999. Tables 4-3 and 4-4.

Sector: Commercial

End Use: Ventilation

Product: Hydronic Hot and Chilled Water Circulation, Centrifugal Chiller (25 HP)

Lifetime (years): 23

Baseline Technology: 90\% efficiency

Baseline Installed Cost in 2010: not available

Baseline Annual Energy Consumption: not available

Baseline Life Cycle Cost in 2010: not available

\begin{tabular}{|l|c|c|}
\hline & $\begin{array}{c}\text { Technology for 2010 } \\
\text { Standard }\end{array}$ & $\begin{array}{c}\text { Technology for 2020 } \\
\text { Standard }\end{array}$ \\
\hline Description & $95 \%$ & Same as 2010 \\
\hline Increase in end user cost* $(\$)$ & $\$ 73$ & $\$ 63$ \\
\hline Annual energy savings* $(\mathrm{kWh})$ & 1111 & 1111 \\
\hline CCE $(\$ / \mathrm{kWh})$ & 0.5 & 0.5 \\
\hline Decrease in LCC* $(\$)$ & $\$ 789$ & $\$ 820$ \\
\hline
\end{tabular}

* Relative to baseline technology.

Notes: This product accounts for about $14 \%$ of the energy consumption by Hydronic Hot and Chilled Water Circulation units.

Source(s): Arthur D. Little.1999. "Opportunities for Energy Savings in the Residential and Commercial Sectors with High Efficiency Electric Motors.” Cambridge, MA. December, 1999. Tables 4-5 and 4-6. 
Sector: Commercial

End Use: Ventilation

Product: Hydronic Hot and Chilled Water Circulation, Screw Chiller (10 HP)

Lifetime (years): 20

Baseline Technology: 90\% efficiency

Baseline Installed Cost in 2010: not available

Baseline Annual Energy Consumption: not available

Baseline Life Cycle Cost in 2010: not available

\begin{tabular}{|l|c|c|}
\hline & $\begin{array}{c}\text { Technology for 2010 } \\
\text { Standard }\end{array}$ & $\begin{array}{c}\text { Technology for 2020 } \\
\text { Standard }\end{array}$ \\
\hline Description & $94 \%$ & Same as 2010 \\
\hline Increase in installed cost* $(\$)$ & $\$ 84$ & $\$ 72$ \\
\hline Annual energy savings* $(\mathrm{kWh})$ & 500 & 500 \\
\hline CCE $(\$ / \mathrm{kWh})$ & 1.4 & 1.2 \\
\hline Decrease in LCC* $(\$)$ & $\$ 304$ & $\$ 335$ \\
\hline
\end{tabular}

* Relative to baseline technology.

Notes: This product accounts for about $1 \%$ of the energy consumption by Hydronic Hot and Chilled Water Circulation units.

Source(s): Arthur D. Little. 1999. "Opportunities for Energy Savings in the Residential and Commercial Sectors with High Efficiency Electric Motors.” Cambridge, MA. December, 1999. Tables 4-5 and 4-6.

Sector: Commercial

End Use: Ventilation

Product: Hydronic Hot and Chilled Water Circulation, Reciprocating Chiller (10 HP)

Lifetime (years): 20

Baseline Technology: 88\% efficiency

Baseline Installed Cost in 2010: not available

Baseline Annual Energy Consumption: not available

Baseline Life Cycle Cost in 2010: not available

\begin{tabular}{|l|c|c|}
\hline & $\begin{array}{c}\text { Technology for 2010 } \\
\text { Standard }\end{array}$ & $\begin{array}{c}\text { Technology for 2020 } \\
\text { Standard }\end{array}$ \\
\hline Description & $93 \%$ & Same as 2010 \\
\hline Increase in installed cost* $(\$)$ & $\$ 84$ & $\$ 72$ \\
\hline Annual energy savings* $(\mathrm{kWh})$ & 476 & 476 \\
\hline CCE $(\$ / \mathrm{kWh})$ & 1.5 & 1.3 \\
\hline Decrease in LCC* $(\$)$ & $\$ 286$ & $\$ 306$ \\
\hline
\end{tabular}

* Relative to baseline technology.

Notes: This product accounts for about 13\% of the energy consumption by Hydronic Hot and Chilled Water Circulation units.

Source(s): Arthur D. Little. 1999. "Opportunities for Energy Savings in the Residential and Commercial Sectors with High Efficiency Electric Motors.” Cambridge, MA. December, 1999. Tables 4-5 and 4-6. 
Sector: Commercial

End Use: Ventilation

Product: Hydronic Hot and Chilled Water Circulation, Absorption Chiller (25 HP)

Lifetime (years): 23

Baseline Technology: 90\% efficiency

Baseline Installed Cost in 2010: not available

Baseline Annual Energy Consumption: not available

Baseline Life Cycle Cost in 2010: not available

\begin{tabular}{|l|c|c|}
\hline & $\begin{array}{c}\text { Technology for 2010 } \\
\text { Standard }\end{array}$ & $\begin{array}{c}\text { Technology for 2020 } \\
\text { Standard }\end{array}$ \\
\hline Description & $95 \%$ & Same as 2010 \\
\hline Increase in installed cost* $(\$)$ & $\$ 73$ & $\$ 63$ \\
\hline Annual energy savings* $(\mathrm{kWh})$ & 1250 & 1250 \\
\hline CCE $(\mathrm{q} / \mathrm{kWh})$ & 0.5 & 0.4 \\
\hline Decrease in LCC* $(\$)$ & $\$ 897$ & $\$ 930$ \\
\hline
\end{tabular}

* Relative to baseline technology.

Notes: This product accounts for about $1 \%$ of the energy consumption by Hydronic Hot and Chilled Water Circulation units.

Source(s): Arthur D. Little. 1999. "Opportunities for Energy Savings in the Residential and Commercial Sectors with High Efficiency Electric Motors.” Cambridge, MA. December, 1999. Tables 4-5 and 4-6.

Sector: Commercial

End Use: Ventilation

Product: Hydronic Hot and Chilled Water Circulation, Hydronic Heating (10 HP)

Lifetime (years): 23

Baseline Technology: 90\% efficiency

Baseline Installed Cost in 2010: not available

Baseline Annual Energy Consumption: not available

Baseline Life Cycle Cost in 2010: not available

\begin{tabular}{|l|c|c|}
\hline & $\begin{array}{c}\text { Technology for 2010 } \\
\text { Standard }\end{array}$ & $\begin{array}{c}\text { Technology for 2020 } \\
\text { Standard }\end{array}$ \\
\hline Description & $94 \%$ & Same as 2010 \\
\hline Increase in installed cost* $(\$)$ & $\$ 84$ & $\$ 72$ \\
\hline Annual energy savings* $(\mathrm{kWh})$ & 857 & 857 \\
\hline CCE $(\$ / \mathrm{kWh})$ & 0.8 & 0.7 \\
\hline Decrease in LCC* $(\$)$ & $\$ 581$ & $\$ 609$ \\
\hline
\end{tabular}

* Relative to baseline technology.

Notes: This product accounts for about 70\% of the energy consumption by Hydronic Hot and Chilled Water Circulation units.

Source(s): Arthur D. Little. 1999. "Opportunities for Energy Savings in the Residential and Commercial Sectors with High Efficiency Electric Motors.” Cambridge, MA. December, 1999. Tables 4-5 and 4-6. 
Sector: Commercial

End Use: Ventilation

Product: Cooling Water Circulation, Centrifugal Chiller (25 HP)

Lifetime (years): 23

Baseline Technology: 90\% efficiency

Baseline Installed Cost in 2010: not available

Baseline Annual Energy Consumption: not available

Baseline Life Cycle Cost in 2010: not available

\begin{tabular}{|l|c|c|}
\hline & $\begin{array}{c}\text { Technology for 2010 } \\
\text { Standard }\end{array}$ & $\begin{array}{c}\text { Technology for 2020 } \\
\text { Standard }\end{array}$ \\
\hline Description & $95 \%$ & Same as 2010 \\
\hline Increase in installed cost* $(\$)$ & $\$ 73$ & $\$ 63$ \\
\hline Annual energy savings* $(\mathrm{kWh})$ & 1235 & 1235 \\
\hline CCE $(\$ / \mathrm{kWh})$ & 0.5 & 0.4 \\
\hline Decrease in LCC* $(\$)$ & $\$ 870$ & $\$ 902$ \\
\hline
\end{tabular}

* Relative to baseline technology.

Notes: This product accounts for about 58\% of the energy consumption by Cooling Water Circulation units.

Source(s): Arthur D. Little. 1999. "Opportunities for Energy Savings in the Residential and Commercial Sectors with High Efficiency Electric Motors.” Cambridge, MA. December, 1999. Tables 4-7 and 4-8.

Sector: Commercial

End Use: Ventilation

Product: Cooling Water Circulation, Screw Chiller (10 HP)

Lifetime (years): 20

Baseline Technology: 90\% efficiency

Baseline Installed Cost in 2010: not available

Baseline Annual Energy Consumption: not available

Baseline Life Cycle Cost in 2010: not available

\begin{tabular}{|l|c|c|}
\hline & $\begin{array}{c}\text { Technology for 2010 } \\
\text { Standard }\end{array}$ & $\begin{array}{c}\text { Technology for 2020 } \\
\text { Standard }\end{array}$ \\
\hline Description & $94 \%$ & Same as 2010 \\
\hline Increase in installed cost* $(\$)$ & $\$ 84$ & $\$ 72$ \\
\hline Annual energy savings* $(\mathrm{kWh})$ & 714 & 714 \\
\hline CCE $(\$ / \mathrm{kWh})$ & 1.0 & 0.9 \\
\hline Decrease in LCC* $(\$)$ & $\$ 462$ & $\$ 486$ \\
\hline
\end{tabular}

* Relative to baseline technology.

Notes: This product accounts for about $4 \%$ of the energy consumption by Cooling Water Circulation units.

Source(s): Arthur D. Little. 1999. "Opportunities for Energy Savings in the Residential and Commercial Sectors with High Efficiency Electric Motors.” Cambridge, MA. December, 1999. Tables 4-7 and 4-8. 
Sector: Commercial

End Use: Ventilation

Product: Cooling Water Circulation, Reciprocating Chiller (10 HP)

Lifetime (years): 20

Baseline Technology: 88\% efficiency

Baseline Installed Cost in 2010: not available

Baseline Annual Energy Consumption: not available

Baseline Life Cycle Cost in 2010: not available

\begin{tabular}{|l|c|c|}
\hline & $\begin{array}{c}\text { Technology for 2010 } \\
\text { Standard }\end{array}$ & $\begin{array}{c}\text { Technology for 2020 } \\
\text { Standard }\end{array}$ \\
\hline Description & $93 \%$ & Same as 2010 \\
\hline Increase in installed cost* $(\$)$ & $\$ 84$ & $\$ 72$ \\
\hline Annual energy savings* $(\mathrm{kWh})$ & 381 & 381 \\
\hline CCE $(\$ / \mathrm{kWh})$ & 1.9 & 1.6 \\
\hline Decrease in LCC* $(\$)$ & $\$ 207$ & $\$ 226$ \\
\hline
\end{tabular}

* Relative to baseline technology.

Notes: This product accounts for about $29 \%$ of the energy consumption by Cooling Water Circulation units.

Source(s): Arthur D. Little. 1999. "Opportunities for Energy Savings in the Residential and Commercial Sectors with High Efficiency Electric Motors.” Cambridge, MA. December, 1999. Tables 4-7 and 4-8.

Sector: Commercial

End Use: Ventilation

Product: Cooling Water Circulation, Li-Br Water Absorption Chiller (25 HP)

Lifetime (years): 23

Baseline Technology: 90\% efficiency

Baseline Installed Cost in 2010: not available

Baseline Annual Energy Consumption: not available

Baseline Life Cycle Cost in 2010: not available

\begin{tabular}{|l|c|c|}
\hline & $\begin{array}{c}\text { Technology for 2010 } \\
\text { Standard }\end{array}$ & $\begin{array}{c}\text { Technology for 2020 } \\
\text { Standard }\end{array}$ \\
\hline Description & $95 \%$ & Same as 2010 \\
\hline Increase in installed cost* $(\$)$ & $\$ 73$ & $\$ 63$ \\
\hline Annual energy savings* $(\mathrm{kWh})$ & 1250 & 1250 \\
\hline CCE $(\$ / \mathrm{kWh})$ & 0.5 & 0.4 \\
\hline Decrease in LCC* $(\$)$ & $\$ 881$ & $\$ 914$ \\
\hline
\end{tabular}

* Relative to baseline technology.

Notes: This product accounts for about $8 \%$ of the energy consumption by Cooling Water Circulation units.

Source(s): Arthur D. Little. 1999. "Opportunities for Energy Savings in the Residential and Commercial Sectors with High Efficiency Electric Motors.” Cambridge, MA. December, 1999. Tables 4-7 and 4-8. 
Sector: Commercial

End Use: Ventilation

Product: Heat Rejection, Large Unitary (5 HP)

Lifetime (years): 15

Baseline Technology: 85\% efficiency

Baseline Installed Cost in 2010: not available

Baseline Annual Energy Consumption: not available

Baseline Life Cycle Cost in 2010: not available

\begin{tabular}{|l|c|c|}
\hline & $\begin{array}{c}\text { Technology for 2010 } \\
\text { Standard }\end{array}$ & $\begin{array}{c}\text { Technology for 2020 } \\
\text { Standard }\end{array}$ \\
\hline Description & $90 \%$ & Same as 2010 \\
\hline Increase in installed cost* $(\$)$ & $\$ 46$ & $\$ 39$ \\
\hline Annual energy savings* $(\mathrm{kWh})$ & 299 & 299 \\
\hline CCE $(\$ / \mathrm{kWh})$ & 1.4 & 1.2 \\
\hline Decrease in LCC* $(\$)$ & $\$ 164$ & $\$ 176$ \\
\hline
\end{tabular}

* Relative to baseline technology.

Notes: This product accounts for about $14 \%$ of the energy consumption by Heat Rejection units.

Source(s): Arthur D. Little. 1999. "Opportunities for Energy Savings in the Residential and Commercial Sectors with High Efficiency Electric Motors.” Cambridge, MA. December, 1999. Tables 4-9 and 4-10.

Sector: Commercial

End Use: Ventilation

Product: Heat Rejection, Air Cooled Screw Chillers (2 HP)

Lifetime (years): 20

Baseline Technology: 85\% efficiency

Baseline Installed Cost in 2010: not available

Baseline Annual Energy Consumption: not available

Baseline Life Cycle Cost in 2010: not available

\begin{tabular}{|l|c|c|}
\hline & $\begin{array}{c}\text { Technology for 2010 } \\
\text { Standard }\end{array}$ & $\begin{array}{c}\text { Technology for 2020 } \\
\text { Standard }\end{array}$ \\
\hline Description & $92 \%$ & Same as 2010 \\
\hline Increase in installed cost* $(\$)$ & $\$ 14$ & $\$ 12$ \\
\hline Annual energy savings* $(\mathrm{kWh})$ & 1667 & 1667 \\
\hline CCE $(\$ / \mathrm{kWh})$ & 0.1 & 0.1 \\
\hline Decrease in LCC* $(\$)$ & $\$ 1156$ & $\$ 1186$ \\
\hline
\end{tabular}

* Relative to baseline technology.

Notes: This product accounts for about $1 \%$ of the energy consumption by Heat Rejection units.

Source(s): Arthur D. Little. 1999. "Opportunities for Energy Savings in the Residential and Commercial Sectors with High Efficiency Electric Motors.” Cambridge, MA. December, 1999. Tables 4-9 and 4-10. 
Sector: Commercial

End Use: Ventilation

Product: Heat Rejection, Air Cooled Reciprocating Chillers (2 HP)

Lifetime (years): 20

Baseline Technology: 85\% efficiency

Baseline Installed Cost in 2010: not available

Baseline Annual Energy Consumption: not available

Baseline Life Cycle Cost in 2010: not available

\begin{tabular}{|l|c|c|}
\hline & $\begin{array}{c}\text { Technology for 2010 } \\
\text { Standard }\end{array}$ & $\begin{array}{c}\text { Technology for 2020 } \\
\text { Standard }\end{array}$ \\
\hline Description & $92 \%$ & Same as 2010 \\
\hline Increase in installed cost* $(\$)$ & $\$ 14$ & $\$ 12$ \\
\hline Annual energy savings* $(\mathrm{kWh})$ & 952 & 952 \\
\hline CCE $(\$ / \mathrm{kWh})$ & 0.1 & 0.1 \\
\hline Decrease in LCC* $(\$)$ & $\$ 654$ & $\$ 672$ \\
\hline
\end{tabular}

* Relative to baseline technology.

Notes: This product accounts for about $9 \%$ of the energy consumption by Heat Rejection units.

Source(s): Arthur D. Little. 1999. "Opportunities for Energy Savings in the Residential and Commercial Sectors with High Efficiency Electric Motors.” Cambridge, MA. December, 1999. Tables 4-9 and 4-10.

Sector: Commercial

End Use: Ventilation

Product: Heat Rejection, Cooling Tower (10 HP)

Lifetime (years): 20

Baseline Technology: 85\% efficiency

Baseline Installed Cost in 2010: not available

Baseline Annual Energy Consumption: not available

Baseline Life Cycle Cost in 2010: not available

\begin{tabular}{|l|c|c|}
\hline & $\begin{array}{c}\text { Technology for 2010 } \\
\text { Standard }\end{array}$ & $\begin{array}{c}\text { Technology for 2020 } \\
\text { Standard }\end{array}$ \\
\hline Description & $92 \%$ & Same as 2010 \\
\hline Increase in installed cost* $(\$)$ & $\$ 84$ & $\$ 72$ \\
\hline Annual energy savings* $(\mathrm{kWh})$ & 559 & 559 \\
\hline CCE $(\mathbb{k} / \mathrm{kWh})$ & 1.4 & 1.2 \\
\hline Decrease in LCC* $(\$)$ & $\$ 309$ & $\$ 330$ \\
\hline
\end{tabular}

* Relative to baseline technology.

Notes: This product accounts for about $5 \%$ of the energy consumption by Heat Rejection units.

Source(s): Arthur D. Little. 1999. "Opportunities for Energy Savings in the Residential and Commercial Sectors with High Efficiency Electric Motors.” Cambridge, MA. December, 1999. Tables 4-9 and 4-10. 
Sector: Commercial

End Use: Water Heating

Product: Storage Water Heater, Gas-Fired (120 gallon)

Lifetime (years): 7

Baseline Technology: 78\% thermal efficiency

Baseline Installed Cost in 2010: \$2,184

Baseline Annual Energy Consumption: $101 \mathrm{MMBtu}$

Baseline Life Cycle Cost in 2010: \$6,181

\begin{tabular}{|l|c|c|}
\hline & $\begin{array}{c}\text { Technology for 2010 } \\
\text { Standard }\end{array}$ & $\begin{array}{c}\text { Technology for 2020 } \\
\text { Standard }\end{array}$ \\
\hline Description & $82 \%$ thermal efficiency & Same as 2010 \\
\hline Increase in installed cost* $(\$)$ & $\$ 116$ & $\$ 100$ \\
\hline Annual energy savings* $($ MMBtu) & 4.9 & 4.9 \\
\hline CCE $($ /MMBtu) & $\$ 4.01$ & $\$ 3.45$ \\
\hline Decrease in LCC* $\$$ ( $)$ & $\$ 79$ & $\$ 115$ \\
\hline
\end{tabular}

* Relative to baseline technology.

Notes: This product accounts for about $11 \%$ of the gas-fired water heater market.

Source(s): U.S. Department of Energy (DOE)-Office of Energy Efficiency and Renewable Energy. 2000.

"Screening Analysis for EPACT-Covered Commercial HVAC and Water-Heating Equipment, Volume 1 - Main Report and Volume 2 - Appendix Material.” Washington, DC. April, 2000. Table 2.4, Table 2.5, Table 3.8, Appendix D3-D80.

Sector: Commercial

End Use: Water Heating

Product: Storage Water Heater, Gas-Fired (199 gallon)

Lifetime (years): 7

Baseline Technology: 78\% thermal efficiency

Baseline Installed Cost in 2010: \$2,722

Baseline Annual Energy Consumption: 165 MMBtu

Baseline Life Cycle Cost in 2010: \$9,260

\begin{tabular}{|l|c|c|}
\hline & $\begin{array}{c}\text { Technology for 2010 } \\
\text { Standard }\end{array}$ & $\begin{array}{c}\text { Technology for 2020 } \\
\text { Standard }\end{array}$ \\
\hline Description & $82 \%$ thermal efficiency & Same as 2010 \\
\hline Increase in installed cost* $(\$)$ & $\$ 193$ & $\$ 166$ \\
\hline Annual energy savings* $(\mathrm{MMBtu})$ & 8.1 & 8.1 \\
\hline CCE $(\$$ MMBtu) & $\$ 4.07$ & $\$ 3.50$ \\
\hline Decrease in LCC* $\$$ ) & $\$ 126$ & $\$ 185$ \\
\hline
\end{tabular}

* Relative to baseline technology.

Notes: This product accounts for about $23 \%$ of the gas-fired water heater market.

Source(s): U.S. Department of Energy (DOE)-Office of Energy Efficiency and Renewable Energy. 2000.

"Screening Analysis for EPACT-Covered Commercial HVAC and Water-Heating Equipment, Volume 1 - Main Report and Volume 2 - Appendix Material.” Washington, DC. April, 2000. Table 2.4, Table 2.5, Table 3.8, Appendix D3-D80. 
Sector: Commercial

End Use: Water Heating

Product: Storage Water Heater, Gas-Fired (360 gallon)

Lifetime (years): 7

Baseline Technology: 80\% thermal efficiency

Baseline Installed Cost in 2010: \$4,828

Baseline Annual Energy Consumption: 284 MMBtu

Baseline Life Cycle Cost in 2010: \$16,066

\begin{tabular}{|l|c|c|}
\hline & $\begin{array}{c}\text { Technology for 2010 } \\
\text { Standard }\end{array}$ & $\begin{array}{c}\text { Technology for 2020 } \\
\text { Standard }\end{array}$ \\
\hline Description & $82 \%$ thermal efficiency & Same as 2010 \\
\hline Increase in installed cost* $(\$)$ & $\$ 175$ & $\$ 151$ \\
\hline Annual energy savings* $(\mathrm{MMBtu})$ & 6.9 & 6.9 \\
\hline CCE $(\$$ MMBtu) & $\$ 4.30$ & $\$ 3.70$ \\
\hline Decrease in LCC* $\$$ ) & $\$ 99$ & $\$ 151$ \\
\hline
\end{tabular}

* Relative to baseline technology.

Notes: This product accounts for about $23 \%$ of the gas-fired water heater market.

Source(s): U.S. Department of Energy (DOE)-Office of Energy Efficiency and Renewable Energy. 2000.

"Screening Analysis for EPACT-Covered Commercial HVAC and Water-Heating Equipment, Volume 1 - Main Report and Volume 2 - Appendix Material.” Washington, DC. April, 2000. Table 2.4, Table 2.5, Table 3.8, Appendix D3-D80.

Sector: Commercial

End Use: Water Heating

Product: Instantaneous Water Heater, Gas-Fired (1000 kBtu/hr)

Lifetime (years): 15

Baseline Technology: 80\% thermal efficiency

Baseline Installed Cost in 2010: \$5,282

Baseline Annual Energy Consumption: 760 MMBtu

Baseline Life Cycle Cost in 2010: \$35,392

\begin{tabular}{|l|c|c|}
\hline & $\begin{array}{c}\text { Technology for 2010 } \\
\text { Standard }\end{array}$ & $\begin{array}{c}\text { Technology for 2020 } \\
\text { Standard }\end{array}$ \\
\hline Description & $83 \%$ thermal efficiency & Same as 2010 \\
\hline Increase in installed cost* $(\$)$ & $\$ 770$ & $\$ 662$ \\
\hline Annual energy savings* (MMBtu) & 27.5 & 27.5 \\
\hline CCE $(\$$ MMBtu) & $\$ 4.76$ & $\$ 4.09$ \\
\hline Decrease in LCC* $(\$)$ & $\$ 319$ & $\$ 537$ \\
\hline
\end{tabular}

* Relative to baseline technology.

Notes: This product accounts for about $6 \%$ of the gas-fired water heater market.

Source(s): U.S. Department of Energy (DOE)-Office of Energy Efficiency and Renewable Energy. 2000.

"Screening Analysis for EPACT-Covered Commercial HVAC and Water-Heating Equipment, Volume 1 - Main Report and Volume 2 - Appendix Material.” Washington, DC. April, 2000. Table 2.4, Table 2.5, Table 3.8, Appendix D3-D80. 
Sector: Commercial

End Use: Water Heating

Product: Instantaneous Tank Water Heater, Gas-Fired (500 kBtu/hr)

Lifetime (years): 15

Baseline Technology: 80\% thermal efficiency

Baseline Installed Cost in 2010: \$7,069

Baseline Annual Energy Consumption: $382 \mathrm{MMBtu}$

Baseline Life Cycle Cost in 2010: \$22,176

\begin{tabular}{|l|c|c|}
\hline & Technology for 2010 Standard & Technology for 2020 Standard \\
\hline Description & 82\% thermal efficiency & Same as 2010 \\
\hline Increase in installed cost* $(\$)$ & $\$ 344$ & $\$ 296$ \\
\hline Annual energy savings* $(\mathrm{MMBtu})$ & 9.3 & 9.3 \\
\hline CCE $(\$$ MMBtu) & $\$ 4.25$ & $\$ 3.65$ \\
\hline Decrease in LCC* $(\$)$ & $\$ 24$ & $\$ 110$ \\
\hline
\end{tabular}

* Relative to baseline technology.

Notes: This product accounts for about $1 \%$ of the gas-fired water heater market.

Source(s): U.S. Department of Energy (DOE)-Office of Energy Efficiency and Renewable Energy. 2000.

"Screening Analysis for EPACT-Covered Commercial HVAC and Water-Heating Equipment, Volume 1 - Main Report and Volume 2 - Appendix Material.” Washington, DC. April, 2000. Table 2.4, Table 2.5, Table 3.8, Appendix D3-D80.

Sector: Commercial

End Use: Lighting

Product: Fluorescent Lamp/Ballast

Lifetime (years): 14

Baseline Technology: F40T12/ES lamp with magnetic ballast (15\% market share); F32T8RE7 lamp with electronic ballast (85\% share)

Baseline Installed Cost in 2010: \$22.6

Baseline Annual Energy Consumption: 324 kWh

Baseline Life Cycle Cost in 2010: \$219

\begin{tabular}{|l|c|c|}
\hline & Technology for 2010 Standard & Technology for 2020 Standard \\
\hline Description & $\begin{array}{c}\text { High-performance T8 lamps with } \\
\text { electronic ballasts and with high- } \\
\text { performance electronic ballasts }\end{array}$ & $\begin{array}{c}\text { High-performance T8 lamps with } \\
\text { high-performance electronic } \\
\text { ballasts }\end{array}$ \\
\hline Increase in installed cost* $(\$)$ & 3.5 & 2.5 \\
\hline Annual energy savings* $(\mathrm{kWh})$ & 27 & 37 \\
\hline CCE $(\$ / \mathrm{kWh})$ & 2 & 1 \\
\hline Decrease in LCC* $(\$)$ & 12 & 20 \\
\hline
\end{tabular}

* Relative to baseline technology.

Notes: Technology mix for 2010 standard assumes a market share of $40 \%$ of high-performance T8 Lamp with electronic ballast and 60\% of high-performance T8 Lamp with high-performance electronic ballast.

Installed costs are aggregated for the technology mix.

To calculate efficiency improvement, Lighting Power Densities for the 2010 and 2020 standards were used in combination with the above market share assumptions; LPDs were calculated by LBNL using adapted ASHRAE/IESNA 90.1 lighting application models.

Source(s): Equipment prices are from www.goodmart.com. Last accessed March 11, 2004. 
Sector: Commercial

End Use: Lighting

Product: High Intensity Discharge Lamp (HID), Low Bay

Lifetime (years): 13.5

Baseline Technology: Mercury Vapor (MV) 20\%; Metal Halide (MH) 55\%; High Pressure Sodium (HPS) 25\%

Baseline Installed Cost in 2010: $\$ 60$

Baseline Annual Energy Consumption: $1140 \mathrm{kWh}$

Baseline Life Cycle Cost in 2010: \$769

\begin{tabular}{|l|c|c|}
\hline & $\begin{array}{c}\text { Technology for 2010 } \\
\text { Standard }\end{array}$ & $\begin{array}{c}\text { Technology for 2020 } \\
\text { Standard }\end{array}$ \\
\hline Description & Pulse MH 75\%; HPS 25\% & $\begin{array}{c}\text { Pulse MH/SSB 75\%; } \\
\text { HPS 25\% }\end{array}$ \\
\hline Increase in installed cost* $(\$)$ & 24 & 32 \\
\hline Annual energy savings* $(\mathrm{kWh})$ & 159 & 196 \\
\hline CCE $(\$ / \mathrm{kWh})$ & 3.0 & 2.9 \\
\hline Decrease in LCC* $(\$)$ & 52 & 71 \\
\hline
\end{tabular}

* Relative to baseline technology.

Notes: SSB = solid state electronic ballast; installed costs are aggregated for the technology mix.

To calculate efficiency improvement, Lighting Power Densities for the 2010 and 2020 standards were used in combination with the above market share assumptions; LPDs were calculated by LBNL using adapted ASHRAE/IESNA 90.1 lighting application models.

Source(s): Equipment prices are from www.goodmart.com. Last accessed March 11, 2004.

Sector: Commercial

End Use: Lighting

Product: High Intensity Discharge Lamp (HID), High Bay

Lifetime (years): 13.5

Baseline Technology: Mercury Vapor (MV) 20\%; Metal Halide (MH) 55\%; High Pressure Sodium (HPS) 25\% Baseline Installed Cost in 2010: \$70

Baseline Annual Energy Consumption: 1915 kWh

Baseline Life Cycle Cost in 2010: \$1249

\begin{tabular}{|l|c|c|}
\hline & $\begin{array}{c}\text { Technology for 2010 } \\
\text { Standard }\end{array}$ & $\begin{array}{c}\text { Technology for 2020 } \\
\text { Standard }\end{array}$ \\
\hline Description & Pulse MH 75\%; HPS 25\% & $\begin{array}{c}\text { Pulse MH/SSB 75\%; } \\
\text { HPS 25\% }\end{array}$ \\
\hline Increase in installed cos**(\$) & 16.3 & 24.6 \\
\hline Annual energy savings* $(\mathrm{kWh})$ & 373 & 435 \\
\hline CCE (\$/kWh) & 1.0 & 1.0 \\
\hline Decrease in LCC* $(\$)$ & 193 & 236 \\
\hline
\end{tabular}

* Relative to baseline technology.

Notes: SSB = solid state electronic ballast; Installed costs are aggregated for the technology mix.

Source(s): Equipment prices are from www.goodmart.com. Last accessed March 11, 2004.

Lighting Power Densities for the 2010 and 2020 standards were based on the above assumptions, as calculated by LBNL using adapted ASHRAE/IESNA 90.1 lighting application models. 
Sector: Commercial

End Use: Refrigeration

Product: Supermarket Units

Lifetime (years): 10

Baseline Technology: Current Technology (characteristics uncertain)

\begin{tabular}{|l|c|c|}
\hline & $\begin{array}{c}\text { Technology for 2010 } \\
\text { Standard }\end{array}$ & $\begin{array}{c}\text { Technology for 2020 } \\
\text { Standard }\end{array}$ \\
\hline Description & $\begin{array}{c}16 \% \text { efficiency } \\
\text { improvement* }\end{array}$ & Same as 2010 \\
\hline Increase in installed cost* $(\$)$ & $\$ 21,490$ & $\$ 18,475$ \\
\hline Annual energy savings* $(\mathrm{kWh})$ & 248,946 & 248,946 \\
\hline CCE $(\$ / \mathrm{kWh})$ & 1.2 & 1.1 \\
\hline Decrease in LCC* $(\$)$ & $\$ 6918$ & $\$ 7937$ \\
\hline
\end{tabular}

* Relative to baseline technology.

Notes:

Source(s): Arthur D. Little. 1996. "Energy Savings Potential for Commercial Refrigeration Equipment.” Cambridge, MA. June, 1996. Table 5-10.

Sector: Commercial

End Use: Refrigeration

Product: Beverage Merchandizer

Lifetime (years): 8.5

Baseline Technology: Current Technology (characteristics uncertain)

\begin{tabular}{|l|c|c|}
\hline & $\begin{array}{c}\text { Technology for 2010 } \\
\text { Standard }\end{array}$ & $\begin{array}{c}\text { Technology for 2020 } \\
\text { Standard }\end{array}$ \\
\hline Description & $\begin{array}{c}\text { 61\% efficiency } \\
\text { improvement* }\end{array}$ & Same as 2010 \\
\hline Increase in installed cost* $(\$)$ & $\$ 344$ & $\$ 295$ \\
\hline Annual energy savings* $(\mathrm{kWh})$ & 2375 & 2375 \\
\hline CCE $(\$ / \mathrm{kWh})$ & 2.1 & 1.8 \\
\hline Decrease in LCC* $(\$)$ & $\$ 3$ & $\$ 11$ \\
\hline
\end{tabular}

* Relative to baseline technology.

Notes:

Source(s): Arthur D. Little. 1996. "Energy Savings Potential for Commercial Refrigeration Equipment.” Cambridge, MA. June, 1996. Table 5-17. 
Sector: Commercial

End Use: Refrigeration

Product: Reach-In Freezers

Lifetime (years): 9

Baseline Technology: Current Technology (characteristics uncertain)

\begin{tabular}{|l|c|c|}
\hline & $\begin{array}{c}\text { Technology for 2010 } \\
\text { Standard }\end{array}$ & $\begin{array}{c}\text { Technology for 2020 } \\
\text { Standard }\end{array}$ \\
\hline Description & $\begin{array}{c}\text { 52\% efficiency } \\
\text { improvement* }\end{array}$ & Same as 2010 \\
\hline Increase in installed cost* $(\$)$ & $\$ 465$ & $\$ 424$ \\
\hline Annual energy savings* $(\mathrm{kWh})$ & 2687 & 2687 \\
\hline CCE $(\$ / \mathrm{kWh})$ & 2.5 & 2.3 \\
\hline Decrease in LCC* $(\$)$ & $\$ 12$ & $\$ 23$ \\
\hline
\end{tabular}

* Relative to baseline technology.

Notes:

Source(s): Arthur D. Little. 1996. "Energy Savings Potential for Commercial Refrigeration Equipment.” Cambridge, MA. June, 1996. Table 5-18.

Sector: Commercial

End Use: Refrigeration

Product: Reach-In Refrigerators

Lifetime (years): 9

Baseline Technology: Current Technology (characteristics uncertain)

\begin{tabular}{|l|c|c|}
\hline & $\begin{array}{c}\text { Technology for 2010 } \\
\text { Standard }\end{array}$ & $\begin{array}{c}\text { Technology for 2020 } \\
\text { Standard }\end{array}$ \\
\hline Description & $\begin{array}{c}\text { 38\% efficiency } \\
\text { improvement* }\end{array}$ & Same as 2010 \\
\hline Increase in installed cost* $(\$)$ & $\$ 212$ & $\$ 183$ \\
\hline Annual energy savings* $(\mathrm{kWh})$ & 1631 & 1631 \\
\hline CCE $(\$ / \mathrm{kWh})$ & 1.9 & 1.6 \\
\hline Decrease in LCC* $(\$)$ & $\$ 162$ & $\$ 191$ \\
\hline
\end{tabular}

* Relative to baseline technology.

Notes:

Source(s): Arthur D. Little. 1996. "Energy Savings Potential for Commercial Refrigeration Equipment.” Cambridge, MA. June, 1996. Table 5-19. 
Sector: Commercial

End Use: Refrigeration

Product: Ice Machines

Lifetime (years): 8.5

Baseline Technology: Current Technology (characteristics uncertain)

\begin{tabular}{|l|c|c|}
\hline & $\begin{array}{c}\text { Technology for 2010 } \\
\text { Standard }\end{array}$ & $\begin{array}{c}\text { Technology for 2020 } \\
\text { Standard }\end{array}$ \\
\hline Description & $\begin{array}{c}\text { 23\% efficiency } \\
\text { improvement* }\end{array}$ & Same as 2010 \\
\hline Increase in installed cost* $(\$)$ & $\$ 221$ & $\$ 190$ \\
\hline Annual energy savings* $(\mathrm{kWh})$ & 1141 & 1141 \\
\hline CCE $(\mathrm{q} / \mathrm{kWh})$ & 2.8 & 2.4 \\
\hline Decrease in LCC* $(\$)$ & $\$ 15$ & $\$ 30$ \\
\hline
\end{tabular}

* Relative to baseline technology.

Notes:

Source(s): Arthur D. Little. 1996. “Energy Savings Potential for Commercial Refrigeration Equipment.” Cambridge, MA. June, 1996. Table 5-20.

Sector: Commercial

End Use: Refrigeration

Product: Refrigerated Vending Machines

Lifetime (years): 8.5

Baseline Technology: Current Technology (characteristics uncertain)

\begin{tabular}{|l|c|c|}
\hline & $\begin{array}{c}\text { Technology for 2010 } \\
\text { Standard }\end{array}$ & $\begin{array}{c}\text { Technology for 2020 } \\
\text { Standard }\end{array}$ \\
\hline Description & $\begin{array}{c}\text { 51\% efficiency } \\
\text { improvement* }\end{array}$ & Same as 2010 \\
\hline Increase in installed cost* $(\$)$ & $\$ 308$ & $\$ 265$ \\
\hline Annual energy savings* $(\mathrm{kWh})$ & 1540 & 1540 \\
\hline CCE $(\mathbb{\$} / \mathrm{kWh})$ & 2.9 & 2.5 \\
\hline Decrease in LCC* $(\$)$ & $-\$ 1$ & $\$ 4$ \\
\hline
\end{tabular}

* Relative to baseline technology.

\section{Notes:}

Source(s): Arthur D. Little. 1996. “Energy Savings Potential for Commercial Refrigeration Equipment.” Cambridge, MA. June, 1996. Table 5-21. 
Sector: Commercial

End Use: Refrigeration

Product: Walk-In Coolers

Lifetime (years): 10

Baseline Technology: Current Technology (characteristics uncertain)

\begin{tabular}{|l|c|c|}
\hline & $\begin{array}{c}\text { Technology for 2010 } \\
\text { Standard }\end{array}$ & $\begin{array}{c}\text { Technology for 2020 } \\
\text { Standard }\end{array}$ \\
\hline Description & $\begin{array}{c}46 \% \text { efficiency } \\
\text { improvement* }\end{array}$ & Same as 2010 \\
\hline Increase in installed cost* $(\$)$ & $\$ 1611$ & $\$ 1385$ \\
\hline Annual energy savings* $(\mathrm{kWh})$ & 19,370 & 19,370 \\
\hline CCE $(\$ / \mathrm{kWh})$ & 1.2 & 1.0 \\
\hline Decrease in LCC* $(\$)$ & $\$ 13$ & $\$ 85$ \\
\hline
\end{tabular}

* Relative to baseline technology.

Notes:

Source(s): Arthur D. Little. 1996. "Energy Savings Potential for Commercial Refrigeration Equipment.” Cambridge, MA. June, 1996. Table 5-23.

Sector: Commercial

End Use: Refrigeration

Product: Walk-In Freezers

Lifetime (years): 10

Baseline Technology: Current Technology (characteristics uncertain)

\begin{tabular}{|l|c|c|}
\hline & $\begin{array}{c}\text { Technology for 2010 } \\
\text { Standard }\end{array}$ & $\begin{array}{c}\text { Technology for 2020 } \\
\text { Standard }\end{array}$ \\
\hline Description & $\begin{array}{c}48 \% \text { efficiency } \\
\text { improvement* }\end{array}$ & Same as 2010 \\
\hline Increase in installed cost* $(\$)$ & $\$ 1572$ & $\$ 1351$ \\
\hline Annual energy savings* $(\mathrm{kWh})$ & 7517 & 7517 \\
\hline CCE $(\$ / \mathrm{kWh})$ & 3.0 & 2.6 \\
\hline Decrease in LCC* $(\$)$ & $-\$ 44$ & $\$ 69$ \\
\hline
\end{tabular}

* Relative to baseline technology.

Notes:

Source(s): Arthur D. Little. 1996. "Energy Savings Potential for Commercial Refrigeration Equipment.” Cambridge, MA. June, 1996. Table 5-24. 
Sector: Commercial

End Use: Office Equipment

Product: Personal Computers

Lifetime (years): 5

Baseline Technology: Current standby power

\begin{tabular}{|l|c|c|}
\hline & Technology for 2010 Standard & Technology for 2020 Standard \\
\hline Description & Standby power at FEMP Phase 2 level & Not applicable \\
\hline Increase in user first cost* $(\$)$ & 0.5 & \\
\hline Annual energy savings* $(\mathrm{kWh})$ & 15 & \\
\hline CCE $(\$ / \mathrm{kWh})$ & 0.8 & \\
\hline Decrease in LCC* $(\$)$ & 3.5 & \\
\hline
\end{tabular}

* Relative to baseline technology.

Notes: Products include monitors and laptops used in offices. Values given are averages weighted by current levels of shipments.

FEMP Phase 2 level refers to target levels for Federal Energy Management Program.

We did not consider a 2020 standard due to the expected rapid evolution of technology in this area.

Source(s): Unpublished LBNL analysis done in 2003; data inputs based on industry sources and LBNL estimates. See also: Bertoldi, Paolo, Bernard Aebischer, Charles Edlington, Craig Hershberg, Benoit Lebot, Jiang Lin, Tony Marker, Alan Meier, Hidetoshi Nakagami, Yoshiaki Shibata, Hans Paul Siderius, and Carrie Webber. "Standby power use: How big is the problem? What policies and technical solutions can address it?". In 2002 ACEEE Summer Study on Energy Efficiency in Buildings; Pacific Grove, CA; August 18-23 2002. ACEEE, 2002. LBNL-50567

Sector: Commercial

End Use: Office Equipment

Product: Other than Personal Computers

Lifetime (years): 5

Baseline Technology: Current standby power

\begin{tabular}{|l|c|c|}
\hline & Technology for 2010 Standard & Technology for 2020 Standard \\
\hline Description & Standby power at FEMP Phase 2 level & Not applicable \\
\hline Increase in user first cost* $(\$)$ & 0.5 & \\
\hline Annual energy savings* $(\mathrm{kWh})$ & 12 & \\
\hline CCE $(\mathrm{\$} / \mathrm{kWh})$ & 0.9 & \\
\hline Decrease in LCC* $(\$)$ & 2.9 & \\
\hline
\end{tabular}

* Relative to baseline technology.

Notes: Products include printers, copiers, scanners and fax machines. Values given are averages weighted by current levels of shipments.

FEMP Phase 2 level refers to target levels for Federal Energy Management Program.

We did not consider a 2020 standard due to the expected rapid evolution of technology in this area.

Source(s): Unpublished LBNL analysis done in 2003; data inputs based on industry sources and LBNL estimates. See also: Bertoldi, Paolo, Bernard Aebischer, Charles Edlington, Craig Hershberg, Benoit Lebot, Jiang Lin, Tony Marker, Alan Meier, Hidetoshi Nakagami, Yoshiaki Shibata, Hans Paul Siderius, and Carrie Webber. "Standby power use: How big is the problem? What policies and technical solutions can address it?". In 2002 ACEEE Summer Study on Energy Efficiency in Buildings; Pacific Grove, CA; August 18-23 2002. ACEEE, 2002. LBNL-50567 


\section{Appendix 2 \\ Calculation of Learning Rate Parameter}

In this study we employ a parameter to estimate the change in manufacturing costs over time for various products that could be subject to standards. We rely on research by economist Richard Newell that he did for DOE to provide a "sound theoretical and empirical basis" for modeling technological advancement for EIA’s National Energy Modeling System (NEMS) forecasts. The premise of this research is the common notion of learning by experience. The central idea is that manufacturers will develop efficiencies of production as the industry as a whole matures. This trend scales with the total historical production of the product in question. Accordingly, an empirical learning curve typically uses cumulative production of the product in question as a measure of experience accumulated. The key impact of the learning is a reduction in input use per product - and thus the price.

Mathematically, the learning relationship is expressed with price varying as a power law in total production:

$$
c=a Q^{-b}
$$

where $c$ is the cost (or input quantity) required to produce the $Q$ th unit of output, $a$ is the cost of the first unit produced, $Q$ is cumulative production, and $b$ is the learning parameter.

For the purposes of this analysis, we are interested in the rate at which cost can be expected to decline in the future as total production grows. Since $a$ is constant, the annual percentage change in cost is dependent on $Q, b$ and the annual change in cumulative production, $\Delta Q$ :

$$
\frac{\Delta c}{c}=\left(\frac{\Delta Q}{Q}\right)^{-b}
$$

The annual change in production in one year equals the shipments for that year. Thus, the rate of change in cost can be determined with total production, shipments and the learning parameter $b$.

Newell concentrated on three products for which historical data were available: room air conditioners, central air conditioners and gas water heaters. The learning parameter $b$ is in principle product-specific. Table 1 summarizes the parameters and results of the learning rate calculation. The learning parameter $b$ was found to be close to 0.4 for each of the products studied, with only a slight variation. Annual shipments from 2002 (the most recent year available) are taken to represent $\Delta Q$, and for the purposes of this calculation, annual shipments

are assumed constant. Inserting the appropriate values for $Q, \Delta Q$ and $b$ for each product yields an annual price decrease rate of $1.3 \%, 1.8 \%$ and $1.3 \%$ for room air conditioners, central air 
conditioners and gas water heaters, respectively. For simplicity, and because $b$ is not determined for all end uses, we use the shipments-weighted average value of $1.5 \%$ for all products.

Table 1. Learning Rate Derivation

\begin{tabular}{|l|c|c|c|}
\hline & $\begin{array}{c}\text { Room Air } \\
\text { Conditioner }\end{array}$ & $\begin{array}{c}\text { Central Air } \\
\text { Conditioner }\end{array}$ & $\begin{array}{c}\text { Gas Water } \\
\text { Heater }\end{array}$ \\
\hline Production through 2002, $Q$ (million) & 171 & 122 & 157 \\
\hline Annual shipments $\Delta Q$ in 2002 (million) & 6.15 & 5.26 & 4.99 \\
\hline Learning parameter $b$ & 0.38 & 0.43 & 0.41 \\
\hline $\begin{array}{l}\text { Annual Percentage Increase in } \\
\text { Production } \Delta Q / Q\end{array}$ & $3.6 \%$ & $4.3 \%$ & $3.2 \%$ \\
\hline Implied Cost Growth Factor $(1+\Delta Q / Q)^{-b}$ & 0.987 & 0.982 & 0.987 \\
\hline $\begin{array}{l}\text { Implied Annual Rate of Decline in Cost } \\
1-(1+\Delta Q / Q)^{-b}\end{array}$ & $1.3 \%$ & $1.8 \%$ & $1.3 \%$ \\
\hline
\end{tabular}

Source: Census Data (quoted in Newell) and Appliance Magazine Beginning production dates are first date for which data are available.

\section{Reference}

Newell, Richard G. DRAFT, Incorporation of Technological Learning into NEMS Buildings Modules. Prepared for Energy Information Administration, Department of Energy, Washington, D.C., September 2000. 


\section{Appendix 3 Derivation of Discount Rates}

The discount rate is the rate at which future monetary values are discounted to establish their present value. In this study, we applied discount rates in two parts of the analysis. In the estimation of consumer impacts, we used discount rates that are appropriate for average residential and commercial consumers. In the estimation of the net economic impacts from the national perspective, we applied alternative discount rates of $7 \%$ and $3.5 \%$.

\section{Discount Rates Used in Consumer Impacts Analysis}

\section{Residential sector}

For the residential sector, we derived discount rates using an approach similar to that used in DOE's recent analysis of residential central air conditioners. ${ }^{1}$

One way of estimating discount rates involves defining the share of various finance methods that are used for purchasing an appliance and then determining the associated interest rates for each of the finance methods. This method focuses on establishing the type of financing utilized for the purchase. For equipment financed through the purchase of a new home, this approach is reasonable.

Replacement equipment for existing homes is usually purchased using cash or some form of credit. One approach is to identify the types of credit used to purchase a given type of equipment, the associated interest rates, and the shares of each credit type in total replacement purchases. Such information is difficult to come by, and there are reasons to favor an alternative approach.

When a household makes a major appliance purchase, the short-term effect may be an increase in debt if the purchase is financed with a dealer loan or credit card, or a decrease in cash if the product is purchased with cash. However, financial theory suggests that in the mediumterm, households should tend to rebalance their overall equity/debt portfolio to maintain approximately the same relative shares of different equity/debt classes. According $t \quad o$ this line of reasoning, the appropriate opportunity cost for purchase of long-lived equipment should reflect a household's overall equity/debt portfolio, and not simply the financial or opportunity cost of the debt or equity used to purchase the equipment.

For example, even though the purchase might be financed through a dealer loan or some other short-term financing vehicle, the more probable effect of the purchase is to either cause the consumer to incur additional credit card debt or forego investment in some type of savingsrelated asset. Cash that was once available to either pay for household expenses or to invest in an asset like the stock market or a savings account now must be earmarked to pay off the equipment purchase, thus causing the consumer to incur additional credit card debt or to lose the opportunity to earn income from assets. 
We estimated the discount rate for new-house equipment based on mortgage interest rate data provided in the Federal Reserve Board's Survey of Consumer Finances (SCF). ${ }^{2}$ This survey indicates that mortgage rates carried by homeowners in 1998 averaged 7.9\%. After adjusting for inflation and interest tax deduction (assuming a 28\% marginal income tax rate), real after-tax interest rates on mortgages averaged $4.2 \%$.

Equipment installed in new homes is financed as part of the mortgage. The Federal Reserve Board's Survey of Consumer Finances (SCF) indicates that mortgage rates carried by homeowners in 1998 averaged 7.9\%. Since these mortgages were initiated over a period of many years, we assume that this rate is a reasonable long-term average. Since mortgage interest is taxdeductible, the effective mortgage rate for the average household with a $28 \%$ marginal income tax rate is $5.7 \%$. Adjustment for inflation brings the rate to $4.2 \%$.

For equipment purchased to replace old or failed equipment, we estimated the opportunity cost by assuming that households will eventually rebalance their equity/debt portfolio after purchase to maintain approximately the same shares as existed prior to the purchase. Regardless of which type of debt or equity the household actually uses to purchase the appliance, the final opportunity cost is equal to the average rate of return on equity or interest on debt, weighted by the percentage shares of each debt/equity type in the household's total financial portfolio.

We estimated the average household equity and debt portfolio from the 1995 and 1998 Survey of Consumer Finances. In considering the household financial portfolio, we exclude highly illiquid types of equity (retirement accounts, life insurance, and other managed assets) and debt on a primary mortgage. We assume that these types of equity are not included in the rebalancing.

We estimated interest or return rates associated with each type of household equity and debt holding from a variety of sources. Rates for second mortgages and credit cards are from 1998 SCF data. We estimated interest rates associated with certificates of deposit (CDs), treasury bills (T-bills), and corporate bonds as an average of the Federal Reserve Board time-series data covering 1977-2001. Based on relative returns to less-liquid assets, we assumed that the interest rate on transactions (checking) accounts averages $2 \%$ real. We estimated annual return associated with household stock holdings as an average of data published by the Stern Business School covering the 1977-2001 period. ${ }^{3}$ We estimated mutual fund rates as an average of the Standard and Poor's (S\&P) 500 stock rate (67\% weight) and the T-bill rate (33\% weight).

Table 1 summarizes the shares of household equity and debt based on the above sources and the real, after-tax interest rates associated with each type of equity or debt. We assumed a marginal tax rate of $28 \%$ and CPI inflation to derive real from nominal values. The weightedaverage real, after-tax interest rate across all types of household debt and equity is $6.7 \%$. 
Table 6. After-Tax Real Interest or Return Rates for Household Debt and Equity Types

\begin{tabular}{|l|c|c|}
\hline \multicolumn{1}{|c|}{ Type } & $\begin{array}{c}\text { Average Share of } \\
\text { Household Debt plus } \\
\text { Equity (\%)* }\end{array}$ & $\begin{array}{c}\text { Mean Rate } \\
\text { (\%) }\end{array}$ \\
\hline Second mortgage & 3.0 & 5.9 \\
\hline Credit card and installment loans & 9.1 & 12.0 \\
\hline Transaction (checking) accounts & 20.0 & 2.0 \\
\hline CD (6-month) & 7.9 & 2.8 \\
\hline Savings bonds (Treasury) & 1.6 & 3.7 \\
\hline Bonds (Corporate AAA) & 8.3 & 4.4 \\
\hline Stocks (S\&P500) & 30.2 & 9.6 \\
\hline Mutual funds & 19.8 & 7.6 \\
\hline Total/Weighted-average discount rate & 100 & 6.7 \\
\hline
\end{tabular}

* 1998 data

In this study, we were not able to separately track equipment purchased with new homes and equipment purchased for replacement. Thus, we derived a weighted-average total discount rate based on the $4.2 \%$ rate for new-home equipment and the $6.7 \%$ rate for replacement equipment. The weighted-average of $5.6 \%$ assumes that two-thirds of total equipment shipments are for replacement equipment. For the analysis of building codes for new homes, however, we used the new-home rate of $4.2 \%$.

\section{Commercial sector}

For the commercial sector, we used the discount rates derived for DOE's recent analysis of commercial air conditioners. DOE/LBNL derived the discount rates for this analysis from estimates of the cost of capital of companies that purchase commercial air-conditioning equipment. Most companies use both debt and equity capital to fund investments, so the typical cost of capital is the weighted average of the cost to the firm of equity and debt financing. ${ }^{4}$

The cost of equity financing was estimated using the capital asset pricing model (CAPM). The CAPM, among the most widely used models to estimate the cost of equity financing, assumes that the cost of equity is proportionate to the amount of systematic risk associated with a firm. The cost of equity financing tends to be high when a firm faces a large degree of systematic risk and the cost tends to be low when the firm faces a small degree of systematic risk.

The degree of systematic risk facing a firm is determined by several variables, including the risk coefficient of a firm, the expected return on "risk free" assets $\left(R_{f}\right)$, and the additional return expected on assets facing average market risk (which is known as the equity risk premium or $E R P)$. The variable used to measure firm risk is termed the risk coefficient or "beta." Beta indicates the degree of risk associated with a given firm relative to the level of risk (or price variability) in the overall stock market. Betas usually vary between 0.5 and 2.0. A firm with a 
beta of 0.5 faces half the risk of other stocks in the market; a firm with a beta of 2.0 faces twice the overall stock market risk.

Following this approach, the cost of equity financing for a particular company is given by the equation:

$$
k_{e}=R_{f}+(\beta * E R P)
$$

where:

$k_{e}=\quad$ cost of equity for a company,

$R_{f}=\quad$ expected return of the risk free asset,

$\beta=\quad$ beta of the company stock, and

$E R P=\quad$ expected equity risk premium.

The cost of debt financing is the yield or interest rate paid on money borrowed by a company (for example, by selling bonds). As defined here, the cost of debt includes compensation for default risk (the risk that a firm will go bankrupt) and excludes deductions for taxes.

We estimated the cost of debt for companies by adding a risk adjustment factor to the current yield on long-term corporate bonds (the risk free rate). This procedure was used to estimate company costs to obtain debt financing. The adjustment factor was based on indicators of company risk, such as credit rating or variability of stock returns.

The discount rate of a company is the weighted average cost of debt and equity financing or the weighted average cost of capital (WACC). It was estimated from the equation:

$$
k=k_{e} \cdot w_{e}+k_{d} \cdot w_{d}
$$

Where,

$k=\quad$ (nominal) cost of capital,

$k_{e}=\quad$ expected rate of return on equity,

$k_{d}=\quad$ expected rate of return on debt,

$w_{e}=\quad$ proportion of equity financing in total annual firm financing, and

$w_{d}=\quad$ proportion of debt financing in total annual firm financing.

The cost of capital is a nominal rate, because it includes anticipated future inflation in the expected returns from stocks and bonds. The real discount rate or WACC deducts expected inflation from the nominal rate. We calculated expected inflation (2.3 percent) from the average of the last five quarters' change in gross domestic product (GDP) prices.

We defined the expected return on "risk free” assets, or risk free rate (5.5 percent), by the yield (December 2001) on long-term government bonds. ${ }^{5}$ The equity risk premium (ERP) represents the difference between the expected (average) stock market return and the risk free rate. The 5.5 percent estimate for the ERP was taken from the Damodaran Online site. ${ }^{6}$ 
A sample of companies used to represent commercial air conditioner purchasers was pulled from a database of 7,319 U.S. companies included in the Damodaran Online site. ${ }^{3}$ This firm database includes most of the publicly traded companies in the United States economy. This database of companies was divided into the categories shown in Table 3 according to their standard industrial code (SIC) code. Financial information was sought for all the retail, property owner, medical service, hotel, and food service firms as well as all of the public for profit and not for profit firms included in the full sample. Financial information was sought for only 10 percent of the industrial and office/service sector firms in the full sample in order keep the data base manageable. The 10 percent sub-sample was chosen by listing the companies alphabetically and drawing every tenth firm on the list. In cases where one or more of the variables needed to estimate the discount rate was missing or could not be obtained, the firm was discarded from the analysis. Overall, about 80 percent of the firms in the full database were discarded for this reason.

Ultimately, a sample of 973 companies was used to represent commercial air conditioner purchasers. For each company, the cost of debt, percent debt financing, and systematic firm risk were drawn from information provided at the Damodaran Online site ${ }^{6}$ (Leonard N. Stern School of Business, New York University), Bloomberg Professional, ${ }^{7}$ and Federal Regulator Energy Commission (FERC) Form 1 filings. ${ }^{8^{*}}$ The cost of debt financing was estimated from the longterm government bond rate (5.5 percent) and the standard deviation of the stock price. Average values for the cost of debt, percent debt financing, and systematic firm risk for companies that purchase commercial air conditioners are shown in Table 2. For the public not-for-profit subsector, we based the cost of capital on average interest rates for Treasury, state, and municipal bonds.

Table 2. Average Values for Variables Used to Estimate Company Discount Rates

\begin{tabular}{|lcl|}
\hline Variable & Average & \multicolumn{1}{c|}{ Source } \\
\hline Risk free asset return $\left(R_{f}\right)$ & $5.5 \%$ & Bloomberg Financial. December 2001 \\
Equity risk premium $(E R P)$ & $5.5 \%$ & Stern Business School, Damodaran Online \\
Expected inflation $(r)$ & $2.3 \%$ & Bureau of Economic Analysis \\
Cost of debt (after tax) $\left(k_{d}\right)$ & $5.9 \%$ & Stern Business School, Damodaran Online \\
Percent debt financing $\left(w_{d}\right)$ & $44 \%$ & Stern Business School, Damodaran Online \\
Systematic firm risk $(\beta)$ & 0.93 & Stern Business School, Damodaran Online \\
\hline
\end{tabular}

\footnotetext{
* Percent debt for firms in the property-owning category was estimated using data from Bloomberg Professional. Cost of debt for publicly owned utilities was taken from FERC Form 1 filings.
} 
We determined the share of each category in total commercial building square footage with package air conditioning from EIA’s 1999 Commercial Building Energy Consumption Survey (CBECS). ${ }^{9}$ From these data, we estimated the shares of total commercial sector purchases of commercial air conditioners (Table 3$)^{* *}$

\section{Table 3. Estimated Shares of Total Purchases of Commercial Air Conditioners}

\begin{tabular}{|lc|}
\hline Category & Percent \\
\hline Property owners and managers & 21.2 \\
Retail firms & 16.5 \\
Medical services & 6.7 \\
Industrial & 4.9 \\
Hotels & 4.0 \\
Food service & 5.3 \\
Office/Service sector & 19.4 \\
Public for profit & 11.0 \\
Public not for profit & 11.0 \\
\hline \multicolumn{2}{|c|}{ Total } \\
\hline
\end{tabular}

Table 4 shows estimates of the real discount rate by category. The weighted average discount rate across all companies is 6.1 percent.

\footnotetext{
** The share of total square footage occupied by property owners is around $40 \%$. However, in some of these buildings the tenants purchase commercial air conditioners. We assumed that this is the case for half of the square footage occupied by property owners. We then allocated the remaining quantity among the other subsectors in proportion to their shares of total square footage.
} 
Table 4. Real Discount Rates by Category for Purchasers of Commercial Air Conditioners

\begin{tabular}{|c|c|c|c|c|c|}
\hline Category & SIC Code & $\begin{array}{c}\text { Estimated } \\
\text { share of } \\
\text { purchases }\end{array}$ & $\begin{array}{c}\text { Mean real } \\
\text { discount } \\
\text { rate } \\
\text { (WACC) }\end{array}$ & $\begin{array}{l}\text { Standard } \\
\text { deviation }\end{array}$ & $\begin{array}{c}\text { Number of } \\
\text { observations }\end{array}$ \\
\hline Retail stores & $53,54,56$ & $16.5 \%$ & $7.1 \%$ & $2.1 \%$ & 218 \\
\hline $\begin{array}{l}\text { Property owners \& } \\
\text { managers }\end{array}$ & 6720 & $21.2 \%$ & $5.2 \%$ & $0.7 \%$ & 11 \\
\hline Medical services & 8000 & $6.7 \%$ & $7.0 \%$ & $1.7 \%$ & 115 \\
\hline Industrial & $1000-4000$ & $4.9 \%$ & $6.9 \%$ & $3.2 \%$ & 253 \\
\hline Hotels & 7000 & $4.0 \%$ & $5.6 \%$ & $1.5 \%$ & 51 \\
\hline Food service & 5400,5812 & $5.3 \%$ & $6.1 \%$ & $1.4 \%$ & 88 \\
\hline Office/services & 5910-9913 & $19.4 \%$ & $6.9 \%$ & $2.1 \%$ & 128 \\
\hline Public for profit & 7950, 8299 & $11.0 \%$ & $7.3 \%$ & $1.8 \%$ & 68 \\
\hline Public not for profit & N.A. & $11.0 \%$ & $3.0 \%$ & $0.7 \%$ & 41 \\
\hline Weighted Average & & N.A. & $6.1 \%$ & $1.6 \%$ & N.A. \\
\hline
\end{tabular}

\section{Discount Rates in Estimation of National Economic Impacts}

In its analyses of the national economic impacts of equipment energy efficiency standards, DOE relies on guidance issued in 1992 by the Office of Management and Budget (OMB) in Circular No. A-94 (Revised), which states (section 8): "In general, public investments and regulations displace both private investment and consumption. ... Constant-dollar benefit-cost analyses of proposed investments and regulations should report net present value and other outcomes determined using a real discount rate of 7 percent. This rate approximates the marginal pretax rate of return on an average investment in the private sector in recent years." $\mathrm{f}$ We apply this "investment discount rate" in this study.

As the OMB guidance notes, regulations such as energy efficiency standards displace both private investment and consumption. Economist Kenneth Arrow notes that "Since consumption is much larger than investment [in the economy], it is reasonable to assume that the appropriate hurdle rate should be closer to the consumption rate... Most estimates of the rate of return on consumption are on the order of 3 or 4 percent." ${ }^{10}$ Based on this line of reasoning, we apply a "consumption discount rate" of 3.5\%. We note that the OMB later advised Federal agencies to use a $3 \%$ discount rate as a sensitivity for calculating the national economic impacts of regulatory policies. ${ }^{\mathrm{g}}$

\footnotetext{
${ }^{\mathrm{f}}$ See http://www.whitehouse.gov/omb/circulars/a094/a094.html\#9. Given the statement that "public investments and regulations displace both private investment and consumption,” it is not clear why the OMB elected to base a discount rate only on displacement of private investment.

g OMB, Guidelines to Standardize Measures of Costs and Benefits and the Format of Accounting
} 


\section{References}

1. U.S. Department of Energy-Office of Building Research and Standards, Technical Support Document: Energy Efficiency Standards for Consumer Products: Residential Central Air Conditioners and Heat Pumps, 2000, U.S. Department of Energy. Washington, DC. Report No. LBNL-47463.

<http://www.eere.energy.gov/buildings/appliance_standards/residential/ac_central.html>

2. The Federal Reserve Board, 1998 Survey of Consumer Finances, 1998. (Last accessed March 15, 2000).

<http://www.federalreserve.gov/pubs/oss/oss2/98/scf98home.html\#summary>

3. Damodaran Online, Leonard N. Stern School of Business, Damodaran. (Posted January 2002) (Last accessed January 2002), < $\underline{\text { http://www.stern.nyu.edu/ adamodar/New_Home_Page/home.html }>}$

4. Modigliani, F. and M. Miller, The Cost of Capital, Corporation Finance and the Theory of Investment. American Economic Review, 1958. June: pp. 261-297.

5. Bloomberg, L. P., Bloomberg Professional, 2002. (Last accessed November 18, 2002). $<\underline{\text { http://about.bloomberg.com/professional/profservice.html }>}$

6. Damodaran, A., Damodaran Online, 2002. Stern School of Business, New York University. (Last accessed January 16, 2002).

<http://www.stern.nyu.edu/ adamodar/New_Home_Page/data.html. $>$

7. Bloomberg, Bloomberg Financial, (Last accessed December 2001, < $\underline{\text { htp://www.bloomberg.com/corp/profservice/professional.html }>}$

8. Federal Energy Management Program, Form 1 Filings, (Last accessed January 21, 2002). $<\underline{\text { http://www.ferc.fed.us/documents/forms/forms.html }>}$

9. U.S. Department of Energy-Energy Information Administration, A Look at Commercial Buildings in 1995: Characteristics, Energy Consumption, and Energy Expenditures, October, 1998. Washington, DC. Report No. DOE/EIA-0625(95).

10. Arrow, K., A Comment on Cooper. The World Bank Research Observer, 2000. 15(2).

Statements. 


\section{Appendix 4 National Impacts Methodology}

\section{Overview}

We estimate national energy savings from percentage efficiency improvement estimates that we apply to the base case forecast provided by EIA's Annual Energy Outlook (AEO) 2004. EIA gives base case energy consumption for each end use for each year of the forecast. Equipment installed after the standards effective year (2010 or 2020) consumes less energy than in the base case, either due to equipment efficiency standards, which apply to all new equipment, or to building codes, which apply to newly constructed homes or commercial buildings. In order to estimate the fraction of equipment stock for which the standard applies, we use a stock accounting model that tracks equipment retirements, replacements, and shipments to newly constructed buildings. Finally, net consumer financial impacts are derived according to implied utility bill savings and incremental capital expenditures.

\section{Stock Accounting for Equipment}

The AEO end use energy consumption forecast represents each appliance's unit energy consumption, multiplied by the number of units in the stock in each year. For each technology, we estimate the average existing stock UEC and the UEC of new equipment in the absence of new standards. In the standards case, equipment shipped after the standard date has a lower UEC. National energy savings is derived from this improvement, according to the accumulation of post-standards stock in each year of the forecast.

New equipment enters the stock either by replacement of retired units or by installation into new buildings. In estimating the amount of new equipment entering the stock due to replacements, we model the retirement of old units, and assume that all retired units are replaced with the same type of equipment. Retirements are modeled with a simple algorithm based on the average lifetime $L$ of each type of equipment, and the vintage $v$ of the existing stock. The survival function $s(L, v)$ gives the ratio of stock in a given year to the total stock in the year of standards implementation. The survival algorithm assumes that no equipment is retired before it has reached two-thirds of its average lifetime, and that all are retired by four-thirds of the average lifetime. In between two-thirds and four-thirds of the lifetime, the survival function is linear. Mathematically, the survival algorithm is given by the following:

$$
\begin{array}{ll}
v<2 /(3 L) & s=1 \\
2 / 3 L<=v<=4 / 3 L & s=2-3 v /(2 L) \\
v>4 / 3 L & s=0
\end{array}
$$


The retirement function is equivalent to the assumption that a constant percentage of each cohort equal to $3 /(2 \mathrm{~L})$ is retired each year between two-thirds and four-thirds of the average lifetime. Figure 1 shows the survival function for an equipment type having an average lifetime of 15 years. Application of the retirement function yields a stock factor for replacements, $S_{R}$.

Figure 1. Survival Function for Equipment Having an Average Lifetime of 15 Years

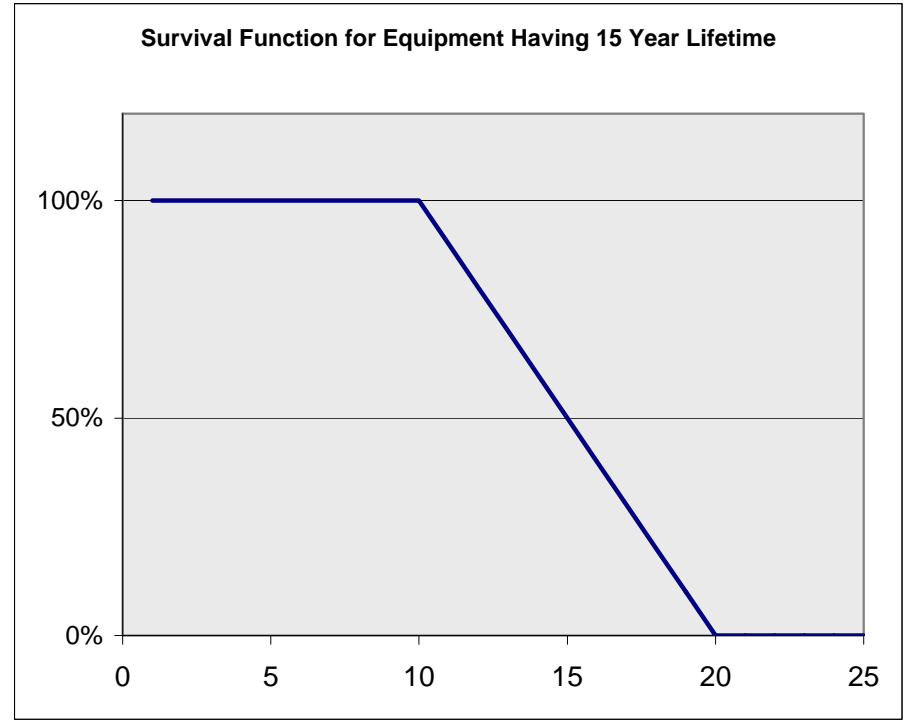

New housing and commercial building space are tracked from the year of standard implementation according to the AEO forecast. The ratio of new buildings constructed since the reference year to the building stock in the reference year is denoted $S_{N}$. We assume that only new equipment is installed in new buildings, and that equipment type market shares remain constant over time. None of the residential buildings built after 2010 are assumed to be subject to demolition during the forecast period. Energy cost savings benefits are assumed to accrue over the first 30 years of the lifetime of the building shell.

\section{Energy Savings}

We calculate a preliminary estimate of total site (delivered) energy use according to existing stock UEC, new equipment UEC, and the stock accounting model described in the previous section. This estimate is refined using the equipment efficiency growth rate incorporated in the AEO forecast. Slight differences between the preliminary estimate and the AEO reference forecast arise due to usage trends (e.g. residential floor space and fuel switching) not captured in our simplified model. To correct for this, we apply a service growth factor $\rho$, defined as the ratio of the AEO forecast to our preliminary estimate. Finally, a baseline factor $b$ is defined as the percentage of new equipment accounted for by baseline models-- those that are not more efficient than required by standards. For residential appliances, we had data that allowed estimation of the portion of the products in the base case that are more efficient that the upgraded standard, and thus would not be impacted by upgraded standards. We estimated the share of units 
sold expected to be more efficient than the upgraded standard based on recent market statistics on Energy Star products.

Site energy savings is equal to the product of the following factors: fractional improvement of equipment affected by standards or codes $\times$ post-standards stock factor $\times$ share of each end use (e.g. electric space heating) claimed by the affected technology (e.g. heat pump) $\times$ the unit energy consumption of new units in the base case; or:

where:

$$
\Delta E=\rho \times b \times E_{0} \times \Delta E f f \times\left(S_{N}+S_{R}\right) \times M S \times U E C_{N}
$$

$\Delta E=$ Site Energy Savings

$\rho=$ Service Growth Factor

$b=$ Baseline Percentage Factor

$E_{0}=$ Base Case End Use Energy Consumption

$\Delta$ Eff $=$ Efficiency Improvement Percentage

$S_{N}=$ New Construction Stock Factor

$S_{R} \times$ Replacement Stock Factor

$M S \times$ Equipment Type Market Share

$U E C_{N}=$ New Equipment Unit Energy Consumption

Primary energy savings is calculated from site savings using conversion provided by the AEO forecast.

\section{Financial Impacts}

Energy savings due to equipment standards and building codes has a direct financial benefit to consumers in the form of decreased utility bills. These are offset, however, by the increased capital expenditure involved in purchasing high-efficiency equipment. Our analysis considers the trade off between utility bill savings and incremental capital costs by calculating life-cycle cost and cost of conserved energy for each technology option. Cost of conserved energy (nondiscounted) for each product is given by:

where

$$
C C E=\frac{\Delta E C}{\sum_{1}^{L} \Delta O C}
$$

$$
\begin{array}{lll}
C C E & = & \text { Cost of Conserved Energy } \\
\triangle E C & = & \text { Incremental Consumer Equipment Cost } \\
\triangle O C= & \text { Annual Consumer Operating Cost Savings } \\
L & = & \text { Equipment Lifetime }
\end{array}
$$

Since the CCE provides an incremental cost for higher-efficiency new equipment, the total incremental capital costs in each year are calculated from the incremental site energy savings 
from one year to the next, which represents additional energy savings due to new equipment. This incremental savings is multiplied by the non-discounted cost of conserved energy of the technology affected by standards. In cases where more than one product in a given end use is affected by standards, a market-weighted average cost of conserved energy is used.

National operating cost savings in each year are equal to delivered energy savings multiplied by the projected price of gas or electricity in that year, as provided by AEO 2004. The net present value (NPV) of financial impacts are calculated using a fixed societal discount rate, applied to each year according to length of time from the reference year (2004). 